\title{
EFEITO DO MANEJO DA ÁGUA DE DRENAGEM NA ADAPTAÇÃO FISIOMORFOLÓGICA DE PLANTAS MESÓFITAS AO ENCHARCAMENTO
}

\author{
Rinaldo de Oliveira Calheiros \\ Engenheiro Agrônomo
}

Orientador: Prof. Dr. Décio Eugênio Cruciani

Tese apresentada à Escola Superior de Agricultura "Luiz de Queiroz", Universidade de São Paulo, para obtenção do título de Doutor em Engenharia Agronômica, Área de Concentração: Irrigação e Drenagem. 


\section{Dados Internacionais de Catalogação na Publicação (CIP) DIVISÃO DE BIBLIOTECA E DOCUMENTAÇĀO - Campus "Luiz de Queiroz"/USP}

\section{Calheiros, Rinaldo de Oliveira}

Efeito do manejo da água de drenagem na adaptação fisiomorfológica de plantas

mesófitas ao encharcamento / Rinaldo de Oliveira Calheiros. - - Piracicaba, 2000.

127 p. : il.

Tese (doutorado) - Escola Superior de Agricultura Luiz de Queiroz, 2000.

Bibliografia.

1. Água de drenagem 2. Efeito do encharcamento 3. Feijăo 4. Fisiologia vegetal 5. Hipoxia 6. Lençol fréatico 7. Manejo 8. Mesófita 9. Planta cultivada 10. Trigo I. Título

CDD 633.11

"Permitida a cópia total ou parcial deste documento, desde que citada a fonte - $\mathbf{O}$ autor" 
À minha mãe, IVONE OLIVEIRA DA SILVA CALHEIROS, e todos meus entes queridos,

dedico 


\section{AGRADECIMENTOS}

Ao professor DÉCIO EUGÊNIO CRUCIANI, pela orientação e amizade.

Aos pesquisadores FLÁVIO B. ARRUDA, EMÍlIO SAKAI, REGINA CELIA DE MATTOS PIRES e MAMOR FUGIWARA, pelo apoio e sugestões.

Aos professores e funcionários do Departamento de Engenharia Rural da ESALQ e aos funcionários do Centro de Ecofisiologia e Biofísica do INSTITUTO AGRONÔMICO pelo apoio.

Ao Departamento de Física da ESALQ pela colaboração e cessão da área experimental.

Ao INSTITUTO AGRONÔMICO pelo apoio e liberação.

Ao CNPq pela bolsa de estudo concedida.

À FAPESP pelo apoio financeiro ao trabalho de pesquisa. 


\section{SUMÁRIO}

Página

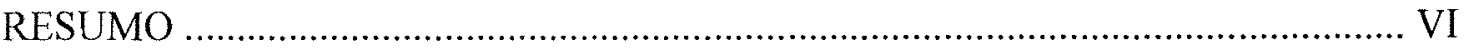

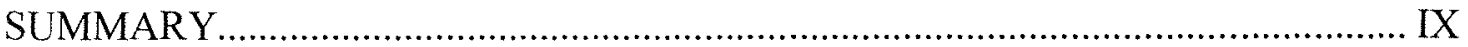

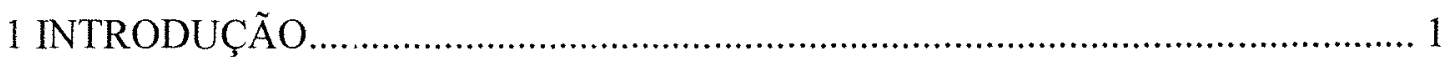

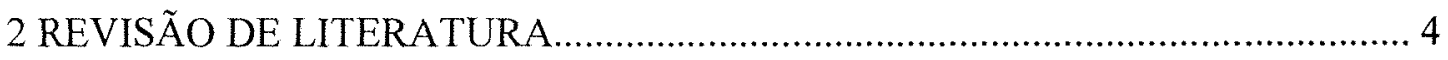

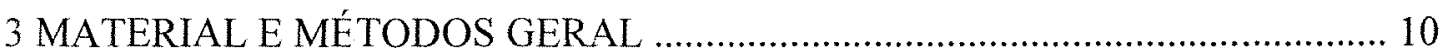

4 EFEITO DE TRES DIFERENTES MANEJOS DO LENÇOL

FREÁTICO NA ADAPTAÇÃO FISIOMORFOLÓGICA DE DUAS

ESPÉCIES DE TRIGO (TRITICUM AESTIVUM, LE

TRITICUM DURUM, L) AO ENCHARCAMENTO_............................................... 15

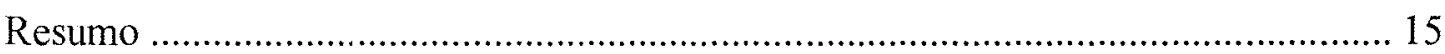

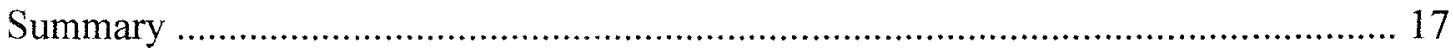

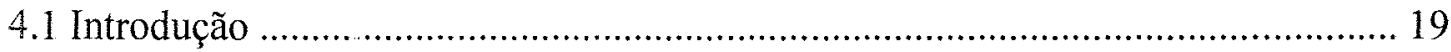

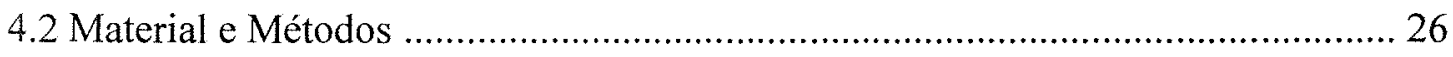

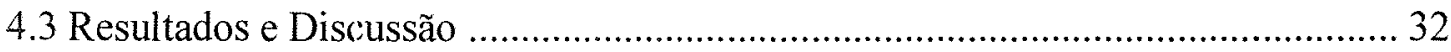

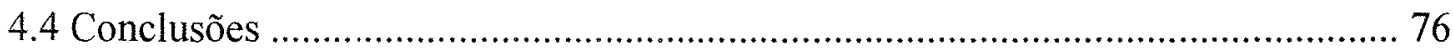

5 EFEITO DE TRES DIFERENTES MANEJOS DO LENÇOL

FREÁTICO NA ADAPTAÇÃO FISIOMORFOLÓGICA DO

FEIJOEIRO (PHASEOLUS VULGARIS,L.) AO ENCHARCAMENTO .................. 78

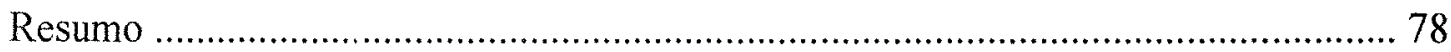

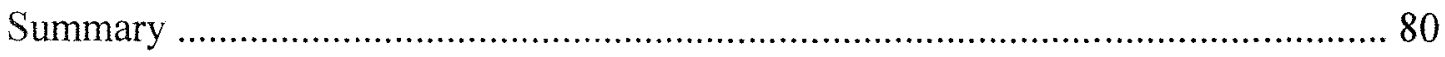


5.1 Introdução

5.2 Material e Métodos

5.3 Resultados e Discussão

5.3.1 Parâmetros climáticos e particularidades do manejo executado 92

5.3.2 Parâmetros biométricos da parte aérea …………………………………….... 94

5.3.3 Adaptações morfológicas de trocas gasosas ..................................................... 97

5.3.4 Fixação biológica do nitrogênio ................................................................... 101

5.3.5 Alterações de parâmetros físicos do solo ...................................................... 104

5.3.6 Transformações fenotípicas ocorridas durante o teste de adaptação

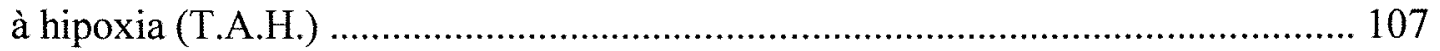

5.3.7 Parâmetros de trocas gasosas ....................................................................... 110

5.3.8 Parâmetros biométricos de produção …………………................................. 112

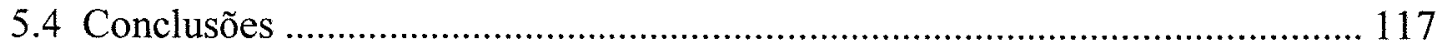

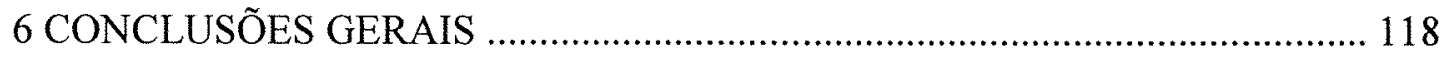

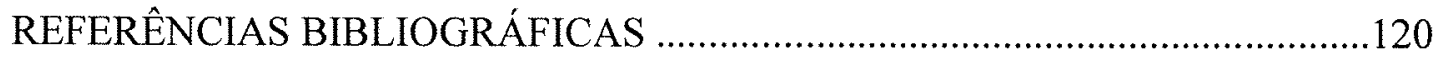




\title{
EFEITO DO MANEJO DA ÁGUA DE DRENAGEM NA ADAPTAÇÃO FISIOMORFOLÓGICA DE PLANTASS MESÓFITAS AO ENCHARCAMENTO
}

\author{
Autor: RINALDO DE OLIVEIRA CALHEIROS \\ Orientador: Prof. Dr. DÉCIO EUGÊNIO CRUCIANI
}

\section{RESUMO}

Estudou-se o efeito de três manejos do lençol freático na indução de adaptações fisio-morfológicas à hipoxia de duas culturas, uma representando as gramíneas, utilizando-se os trigos Triticum aestivum L. e Triticum durum $L$, e, seqüencialmente, uma leguminosa, utilizando-se o Phaseolus vulgaris, l., caracterizando e inferindo-se a influência relativa dos principais fatores físicos e biológicos interferentes. $\mathrm{O}$ experimento foi conduzido na ESALQ/USP, Piracicaba, SP, simulando-se o máximo um meio físico/condição natural de uma várzea. Com o trigo, após a indução no período vegetativo através de períodos hipóxicos com duração progressiva, a eficiência dos manejos foi forçada à manifestar-se através de inundação permanente incluindo o florescimento/formação de grãos. Os resultados apontam que o potencial de água na folha foi afetado pela completa submergência da parte subterrânea, já em sua menor duração, não havendo, porém, correspondência com a manifestação fenotípica da cultura; a resposta diferenciada de exigência nutricional e/ou capacidade extração entre as duas espécies sob hipoxia indica que o sucesso 
produtivo do trigo sob hipoxia pode vir a ser condicionado à estudos específicos sobre suas exigências específicas e, consequentemente, à um plano de fertilização mais ajustado; a adubação foliar não contribuiu para suprir as deficiências nutricionais da planta decorrentes da limitação na absorção via sistema radicular, causada pela hipoxia no solo ou, se o fez, foi de forma insuficiente, sıgerindo-se estudos específicos; a resistividade estomática mostrou-se o parâmetro de maior sensibilidade na planta de trigo sob encharcamento; os manejos empregando curtos períodos de hipoxia induziram adaptações fisio-morfológicas tais que permitiram a sobrevivência das plantas mesmo sob encharcamento contínuo por mais de 50 dias. Essas, porém, não o foram na intensidade ou eficiência que resultassem parâmetros de produção num nível adequado; o manejo do lençol freático mantido a $15 \mathrm{~cm}$ de profundidade durante todo o ciclo fenológico foi o que propiciou melhor performance do trigo; a submergência intermitente mostrou-se altamente prejudicial, com o efeito intensificando-se com o aumento da freqüência da submersão, não sustentando a tese da transmissividade ou acúmulo de induções adaptativas.

No feijấo, também estudou-se o efeito de três manejos do lençol freático utilizando-se a cultivar Bat 477. Após a indução no período vegetativo, a eficiência dos manejos foi forçada à manifestar-se através de inundação temporária no fim do florescimento/formação de vagens. - Os parâmetros biométricos de crescimento, embora acusando prejuízo da hipoxia, evidenciaram a utilização pela planta de mecanismos adaptativos morfológicos (raízes 
adventícias e lenticelas), biológicos (fixação de N) e fisiomorfológicos (resistividade estomática e transpiração); os parâmetros biométricos de produção mostraram que os manejos com o lençol freático mantido a $15 \mathrm{~cm}$ e com sua elevação gradual foram efetivos, permitindo à planta completar seu ciclo, além de resultar menor comprometimento da qualidade de grãos; em plantas submetidas à hipoxia, o estudo da nodulação só será completo se respeitar a dinâmica de emissão de raízes adventícias, dado a gradativa substituição de raízes normais pelas adventícias; a alternância de vantagens relativas nos parâmetros biométricos de colheita entre os manejos de lençol estabilizado a $15 \mathrm{~cm}$ e com elevação gradativa resultando na não diferença estatística no rendimento de grãos, leva-se à recomendação do uso de cultivares de ciclo mais longo nesse tipo de estudo. 


\section{EFFECT OF THREE DIFFERENT WATER TABLE MANAGEMENT ON THE PHYSICAL- MORPHOLOGICAL ADAPTATION OF MESOPHYTE PLANTS TO FLOODING TOLERANCE.}

Author: Rinaldo de Oliveira Calheiros Adviser: Prof. Dr. Décio Eugênio Cruciani

\section{SUMMARY}

It was studied the effect of three different water table management on the physical-morphological adaptation to flooding tolerance of two representatives of the Gramineae groups: Triticum aestivum, L. and Triticum durum, L. and, in sequence, a Leguminosae, Phaseolus vulgaris, $L$. The relative influence of the main physical and biological factors interfering in the adaptation were studied and discussed. The trials were conducted at ESALQ/USP, Piracicaba, SP, under simulation of a natural low land condition. With the wheat, after induction of hipoxia at vegetative growth stage, the efficiency of management was enforced to show by a short-term waterlogging event at reproductive stage. The minor duration of complete submergence was enough to affect the leaf water potential, despite not having correspondence with phenotiphic manifestations; the different requirements and/or extraction capacities of nutrients between the two species demand specific fertilization studies to reach high levels of productivity; the fertilization on leaves was not enough to avoid nutrition deficits in wheat under hipoxia; the diffusion resistance was the most sensitive parameter; the water table managements used resulted in physical- morphological adaptations but these were not enough to reach adequate biometric parameters of 
productivity; the permanent water table at $15 \mathrm{~cm}$ management through all the cultural cycle resulted in the best performance; the intermittent inundation were highly detrimental, with its effects seen progressively to the frequency of inundation, not sustaining the hypothesis of transmissivity of the inducted adaptations.

With the snap beans, cv. BAT 477 , the effects of three different water table managements were also studied. After induction at vegetative growth stage, the efficiency of management was enforced to show by a short-term waterlogging event at reproductive stage. The biometric parameters of growth, although showing damage caused by hipoxia, showed the utilization by the plant of adaptive mechanisms, such as morphological (adventitious roots and lenticels), biological ( $\mathrm{N}$ fixation) and physical-morphological (diffusion resistance and transpiration). On the other hand, the yield biometric parameters showed that the water table maintained at $15 \mathrm{~cm}$, as well as its gradual elevation, were effective in inducing adaptive mechanisms that allowed the plant finish its phenological cycle, besides to result minor damage on quality of the grain. In spite of that, there was not significant difference in the yield comparing to the absence inductive management. Nodulation studies only will be complete if in concordance with the adventitious root emission dynamics. The alternate biometric advantages between the two managements, resulted in no statistically significant differences in the yield, suggesting to be of advantage the use of longer cycle cultivars when in hipoxic conditions. 


\section{1 - INTRODUÇÃ̂O}

A importância da incorporação das várzeas, tecnicamente denominadas terras baixas, ao sistema produtivo, tem sido atraente e bastante incentivado. Três razões básicas tem motivado periódicas ações de fomento governamentais ou de âmbito regionalizado: a) a exploração agrícola atingindo o limite de sua fronteira; b) a forte conotação de ação social, pelo envolvimento de pequenos agricultores; c) alta capacidade de produção de grãos.

Se técnica, econômica e socialmente é inegável que o aproveitamento de terras baixas deva ser incentivado, este deve ser submisso, no entanto, à premissa básica da conservação e promoção ambiental, atendendo-se ao binômio: sistemas produtivos altamente rentáveis e de concepção holística de auto-sustentabilidade.

A auto-sustentabilidade de sistemas de produção agrícola, na prática, só existe com economicidade e essa implica em utilização intensiva através de sucessões de culturas.

Culturas mesófitas exigem equilíbrio na aeração e umidade. Essa dependência da produtividade em relação ao ambiente aerado pode ter sua origem no período Neolítico, quando do início da agricultura desenvolvida em terras secas.

A garantia da aeração do solo leva à pratica da drenagem que pode desnaturalizar a característica básica de ambiente inundado, hidromorfizado, de pouca atividade oxidativa. 
Na prática, a estratégia básica da drenagem tem sido o rebaixamento excessivo do LF durante todo o ciclo da cultura. O objetivo é garantir tanto a aeração permanente do solo como assegurar alto coeficiente de drenagem por ocasião de recargas temporárias e críticas, não controláveis, como por exemplo, precipitação localizada intensa, seguida por inundação decorrente do colapso do sistema de drenagem natural.

Esse inadequado manejo, no entanto, causa sérias modificações ambientais como a degradação e queima excessiva da matéria orgânica, com conseqüente exposição de substratos sub-superfíciais improdutivos. Além disso, o LF muito baixo não atende adequadamente às necessidades de água das plantas, exigindo irrigações, encarecendo o custo de produção.

$\mathrm{Na}$ tentativa da solução desse impasse entre excesso e deficiência de água devem ser considerados os trabalhos referentes à tolerância fisio-morfológica das culturas à ambiente temporariamente não aerado.

A literatura aponta que os efeitos do encharcamento no comportamento fisiológico das plantas tem sido extensivamente monitorados por vários autores. Em menor número, porém, são os trabalhos relacionados ao condicionamento e a indução da adaptação para exploração econômica das culturas. A maioria delas tem sido motivada pelos problemas causados em solos cultivados de terras altas, objetivando elucidar as causas primárias das injurias.

No estudo de plantas sob anoxia, inicialmente, deve-se ter como premissa que tolerância ao encharcamento e tolerância ao déficit de oxigênio não são termos equivalentes. O primeiro implica no elenco de mecanismos mitigadores utilizados pela 
planta, incluindo a habilidade das raízes de eliminar toxinas e uma administração do déficit de oxigênio por transporte interno de $\mathrm{O}_{2}$ das folhas aos órgãos sub-superficiais. O segundo, implica na habilidade da planta em sustentar metabolismos em padrões aeróbicos, ao menos ao nível de manutenção metabólica sob baixa concentração de oxigênio.

À despeito de décadas de pesquisa sobre efeito da anoxia em plantas cultivadas, não há evidencia da identificação de nenhum padrão letal comum às plantas sensíveis. Há uma diversidade de respostas ao encharcamento que são manifestadas dependendo do estratégia de vida e habitat das espécies, sendo muitos e diferentes mecanismos que podem estar envolvidos.

Resultados antagônicos evidenciam que o conhecimento e entendimento da dinâmica das limitações e resposta da planta sob encharcamento é de fundamental importância para a interpretação dos sinais morfo-físiológicos.

Há forte evidência de que o adequado manejo da água no solo e do LF, pode levar ao "endurecimento fisiológico" da cultura através de uma adaptação gradativa dos mecanismos físiológicos e morfológicos da planta, podendo, aliado à introdução de cultivares mais tolerantes, vir à constituir-se na melhor estratégia de exploração de culturas mesófitas em terras baixas.

Por outro lado, fica inquestionável nesta natureza de trabalho, que, pela intensidade, importância relativa e interatividade que desempenham os diferentes fatores específicos de produção, o perfeito entendimento da performance final de uma cultura mesófita sob hipoxia só é permitido se desenvolvido em condições naturais, 
sob adequada e sistemática caracterização e monitoramento destes e, daí então, buscarse interpretar as interações decorrentes.

Assim, os objetivos deste trabalho foram:

Estudar o efeito de diferentes manejos do L. F. nas principais estruturas adaptativas/mitigadoras da hipoxia ùtilizadas por duas culturas mesófitas distintas, uma leguminosa e uma gramínea;

Caracterizando e monitorando os principais fatores de produção interferentes na condição de hipoxia, interpretar seu papel individual e interativo na performance final dessas culturas.

\section{2 - REVISÃO DE LITERATURA}

RICARD et al. (1994) são enfáticos ao afirmar que pouco é conhecido sobre os mecanismos de adaptação à anoxia.

Segundo GLINSKI \& STEPNIEWSKI (1986), a falta de oxigenação no solo causa distúrbios fiıncionais em toda a planta, especialmente na absorção de nutrientes. Em decorrência, segundo KOZLOWSKI (1984), a resposta comum ao encharcamento é inibição da expansão foliar, resultando redução no tamanho e número de folhas, relacionando-se também ao aumento da abcisão foliar.

Por outro lado, segundo TROEDSON et al. (1983) estudos recentes desenvolvidos na Austrália tem mostrado que a soja apresenta uma auto adaptação ao 
ambiente de solo saturado, manifestando taxas de crescimento e produção maiores que sob condição de aeração e bem irrigada. NATHANSON et al. (1984), citam que a cultivar de soja de ciclo curto produziu mais em solo saturado que sob irrigação convencional; enquanto a de ciclo mais longo, sob nível do LF a 15 e $3 \mathrm{~cm}$ de profundidade, produziram, respectivamente, 71 e $65 \%$ mais que sob irrigação convencional. RALPH, (1983) comparando a performance de 14 cultivares de soja sob encharcamento e sob irrigação executada após evaporação de $60 \mathrm{~mm}$ do Tanque Classe A, aponta uma média de $4212 \mathrm{Kg} \mathrm{ha}^{-1}$ para a condição de saturação contra $3439 \mathrm{Kg} \mathrm{ha}^{-1}$ da aspersão.

$\mathrm{O}$ desconhecimento torna-se praticamente total se considerado: para as nossas condições tropicais, conduzida sob condição natural, durante todo o ciclo, com os principais fatores interferentes monitorados. A maioria, dos trabalhos sob efeito da hipoxia em plantas mesófitas, são de laboratório com substrato artificial e/ou esterilizado (WADMAN \& VAN ANDEL, 1985; HUANG ET AL., 1994), com plântulas (WATERS ET AL, 1991; MINCHIN \& SUMMERFIELD, 1976; TROUGHT \& DREW, 1980) e/ou sem a adequada caracterização ou monitoramento do solo/clima/águia (WHITE \& MOLANO, 1994; GARRITY \& PERNITO, 1996; SINGH et al., 1991, UMAHARAN et al., 1997).

Entre culturas, que pode ser considerado o primeiro grau de diferenciação na resistividade à anıxia, a variação pode ser muito significativa (KOZLOWSKI, 1984). A máxima sobrevivência de pontas de raízes de milho é de 15 a 24 hs (ROBERTS, citado por GLINSKI \& STEPNIEWSKI, 1986) enquanto a de raizes de arroz varia de 
5-8 horas (WEBB \& ARMSTRONG, 1983) a 96-120 horas (GLINSKI \& STEPNIEWSKI, 1986).

Trabalhando com vinte espécies nativas de terras alagadas mantidas em ambiente sem oxigênio, BARCLAY \& CRAWFORD (1982) observaram que treze sobreviveram pelo menos 7 dias à temperatura de $22^{\circ} \mathrm{C}$, revigorando-se quando reexpostas ao ar.

Por outro lado, a resistência final das plantas ao encharcamento é muito variável, também em função da temperatura ambiente (com reflexos na taxa evapotranspirométrica), tipo de solo (com os tipos e velocidades intrínsecas de reações químicas) e manejo da água ao longo do ciclo da cultura.

A influência do clima é tão grande que as informações da literatura, principalmente dos trabalhos realizados em climas temperados (maioria), devem ser utilizadas com muito cuidado. Em muitas regiões, as inundações de inverno raramente são uma ameaça, em função de encontrarem as plantas perenes em dormência, sob baixa atividade metabólica e transpirométrica (BLACKWELL, 1983). Já em clima tropical, o efeito do déficit de $\mathrm{O}_{2}$ é maximizado, tanto pela sua menor dissolução em água e maior consumo da planta e microorganismos, como pela velocidade de transformações químicas realizadas no solo.

Tem sido identificado três diferentes tipos de adaptação à anoxia: a) as adaptações metabólicas, b) as morfológicas visando o transporte interno e c) o enraizamento superficial.

Sob o aspecto bioquímico, segundo SCHAFFER et al. (1992), as características metabólicas associadas à tolerância ao encharcamento tem sido 
relacionadas, dentre outras, com a regulação da taxa de glicólise. A tolerância diferenciada ao encharcamento é causada por diferenças nas propriedades indutivas de enzimas glicolíticas, particularmente $\mathrm{ADH}$, cujo aumento de atividade resulta num incremento da concentração de etanol em plantas suscetíveis.

Para culturas anuais mesófitas, no entanto, a via bioquímica de adaptação da planta, por si só, parece não ser suficiente para satisfação de todas necessidades da planta sob hipoxia.

Sob anaerobiose, as células de plantas superiores são hábeis em executar a glicólise e a fermentação por várias horas. Contudo, a produção média de ATP na fermentação é somente $2 \mathrm{~mol} / \mathrm{mol}$ hexose comparada com $36 \mathrm{~mol} / \mathrm{mol}$ produzida na respiração aeróbica. Assim, com o consumo de energia da célula continuando à mesma taxa do período vré-hipóxico, há um forte declínio do nível de energia dentro de poucos minutos. Consequentemente, o crescimento celular cessa, junto com ele o transporte de íns dependente de energia, e a permeabilidade das raízes à água é reduzida, seguindo-se um irregular fluxo de massa dos solutos através das danificadas raízes (DREW, 1992)

Assim, à princípio, a sobrevivência das plantas sob hipoxia temporária ou permanente parece estar mais intensamente ligada a um meio alternativo de suplementação de oxigênio para as raízes da plantas que a uma alternativa metabólica nas raízes.

A associação das diferenciações morfológicas com a bioquímica da planta é atentada por JOLY (1994). Em estudos desenvolvidos com H. courbaril e C. speciosa, espécies de arvores tropicais, observou-se um compromisso entre adaptações 
metabólicas e morfo-anatômicas permitindo-as ocupar temporariamente áreas alagadas. Em ambas espécies, as raízes produziram altas quantidades de etanol e lactato, derivando parte do piruvato para produção de malato. A quantidade de piruvato convertido em malato é determinada pela quantidade de oxigênio difundido da parte aérea para as raízes, através das estruturas morfológicas, oxidando o piruvato via ciclo de Krebs, sendo o excesso convertido em malato. Desta forma, afirma que a produção de ATP no sistema radicular é predominantemente aeróbico.

A alternativa de enraizamento superficial tem o envolvimento de formação de raízes adventícias contendo aerênquima.

Essas raizes tem função de facilitar a absorção de $\mathrm{O}_{2}$ (SENA GOMES \& KOZLOWSKI, 1980b). São de consistência porosa, localizando-se no colo da planta, estendendo-se na sub-superficie do solo. Sua porosidade característica permite, não só mais fácil absorçẫo de água e nutrientes, o transporte interno de $\mathrm{O}_{2}$ como a liberação deste ao meio buscando a necessária oxigenação da rizosfera.

Já os aerêrnquimas se trata do desenvolvimento de espaços contínuos dentro do córtex da planta, que visa diminuir a resistividade a translocação de $\mathrm{O}_{2}$ da parte aérea para o sistema radicular.

É de extrema significância a influência do manejo de água no sucesso de uma cultura sob encharcamento. Se bem empregado, pode ser a chave para a desejável adaptação gradual da cultura à condição de estresse.

De modo geral parece haver um consenso que a anoxia sendo atingida de forma gradativa, passando por estágios intermediários de hipoxia, exerce uma grande importância na adaptação da planta sob encharcamento. JOHNSON et al. (1989) 
reporta que a pré exposição à hipoxia resultou aumento da atividade da $\mathrm{ADH}$, da carga energética da adenina e da sobrevivência do milho. Reportam que se plantas intactas são submetidas à deficiência parcial de oxigênio, recebendo por 18 horas cerca de $1 / 4$ da concentração normal (equilíbrio com o ar), sua subsequente habilidade para tolerar períodos mais extremos de anoxia é enormemente ampliada, podendo permanecer vivas além de 96 horas, mantendo o turgor e a morfologia inalterada. Similarmente, em cevada e milho, concentrações intermediárias de $\mathrm{O}_{2}(3-13 \%)$ produziram mais estímulo da atividade ADH do que as baixas concentrações (<3\%) (WIGNARAJAH \& GREENWAY, 1976).

Trocas abruptas da pressão parcial de oxigênio abaixa significativamente o estado de energia das células e não permitem que ocorram respostas de aclimatação bem como a induṛão de um metabolismo alternativo antes da condição se tornar letal. Ao contrário, a elevação gradativa do nível de anoxia pode levar a planta à adaptações, como observado em raízes hipoxigenadas de milho que desenvolveram troca no padrão de síntese de proteínas (SACHS et al., 1980).

$\mathrm{Na}$ natureza, a concentração de oxigênio em solos encharcados declina desde períodos de poucas horas à dias (TROHGHT \& DREW, 1980), podendo permitir que as células, gradualmente, experimentem déficit de oxigênio, tornando-se hipóxica antes de anóxica.

Talvez esta seja uma fonte de confundimento nas interpretações de dados bibliográficos quanto à resistividade das culturas. Estudos metabólicos normalmente envolvem mudanças abruptas. Por outro lado, estudos sobre biologia molecular tornam o meio anaeróbio de forma gradativa (ROWLAND \& STROMMER, 1986). 


\section{3 - MATERIAL E MÉTODOS GERAIS}

Como premissa básica, em cada fator experimental, procurou-se simular o máximo possível, o meio físico/condição natural de uma área de terras baixas produtiva.

Constituiu-se como parcela experimental caixas de cimento amianto de 1000 litros, com área de $1.9 \mathrm{~m}^{2}$ (Figura 1).

Manejou-se o lençol freático por meio de tubos de 2 polegadas posicionados na base interna das caixas-parcelas, conectados, num sistema de vasos comunicantes, à recipiente adjacente, contendo uma bóia hidráulica que exerceu o controle e manutenção do nível da água (no recipiente) e do lençol freático (na caixa-parcela).

O monitoramento do nível do lençol freático foi executado através de leitura diária de poço de observação perfurado no solo e revestido por tubo de PVC perfurado de 2 polegadas.

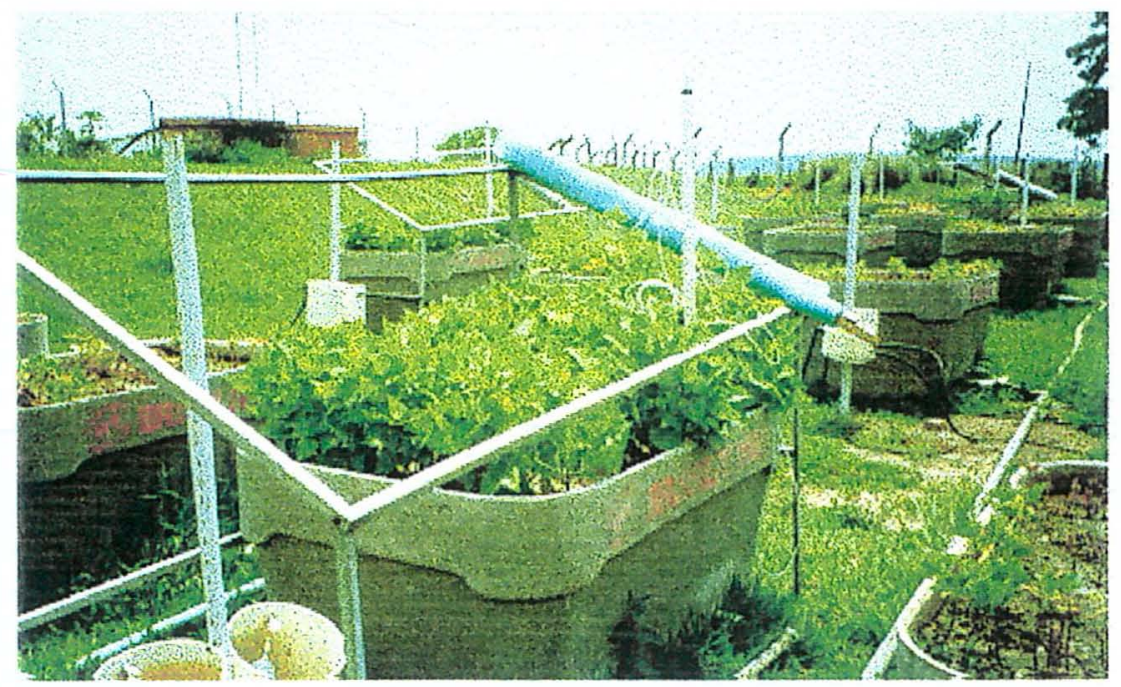

Figura 1. Estruturas de manejo e monitoramento do lençol freático. Piracicaba, SP, ESALQ/USP. 
Após a montagem da estrutura das caixas com esse sistema de irrigação, drenagem e controle do lençol freático, as mesmas foram preenchidas com o substrato composto de uma camada de pedra brita 1 , na altura dos drenos $(10 \mathrm{~cm})$, seguida de outra camada de mesma espessura de pedrisco e, como solo, $60 \mathrm{~cm}$ de Podzólico Vermelho Amarelo abrupto, A moderado e espesso, textura arenosa, unidade Serrinha (Arenic Abruptic Paleudalt), ácido, de média fertilidade, oriundo de várzea situada no Distrito do Paredão Vermelho, Ártemis, SP.

O solo (Tabela 1) apresentava-se ácido, característica normal desse tipo de solo em terras baixas.

Os valores de $9 \mathrm{e} 6 \mathrm{~g} \mathrm{dm}^{-3}$ de matéria orgânica, para os horizontes superficial e subsuperficial, respectivamente, devem ser considerados médios/baixos, premitindo-se inferir que, mesmo sendo um solo de várzea, a área de empréstimo não esteve sujeita ao lençol freático constantemente elevado e que a matéria orgânica, proveniente das inundações periódicas, foi sendo oxidada.

De acordo com o indicado por RAIJ et al. (1996), o teor de potássio apresentava-se baixo e muito baixo para os horizontes superficial e subsuperficial, respectivamente; extremamente deficientes em fósforo cujo teor dentro do intervalo de 0 a $6 \mathrm{mg} \mathrm{dm}^{-3}$ o classifica como muito baixo para culturas anuais; o $\mathrm{Mg}$, no intervalo

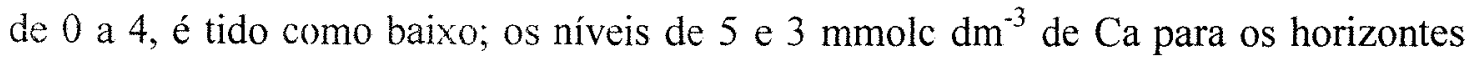
superficial e subsuperficial são considerados médio e baixo; as relações $\mathrm{Ca} / \mathrm{Mg}$ estão no nível normal e os teores de sulfato maior que 10 na camada superficial e $5 \mathrm{mg} \cdot \mathrm{dm}^{-3}$ na subsuperficial podem ser considerados alto e médio, respectivamente. 
A análise da água de rio, não tratada, utilizada na formação e manutenção do lençol freático, arnostrada também nessa ocasião, revelou ser de boa qualidade, sem limitação tanto para utilização de consumo humano como para a prática de irrigação. (Tabela 2).

Tabela 1. Análise química do solo em sua condição inicial. Piracicaba, SP, ESALQ/USP.

\begin{tabular}{|c|c|c|c|c|c|c|c|c|c|c|c|c|}
\hline Prof. & $\mathrm{pH}$ & M.O & $\mathrm{P}$ & $\mathrm{S}-\mathrm{SO} 4$ & K & $\mathrm{Ca}$ & $\mathrm{Mg}$ & $\mathrm{Al}$ & $\mathrm{H}+\mathrm{Al}$ & SB & $\mathrm{T}$ & \\
\hline $\mathrm{cm}$ & $\mathrm{CaCl} 2$ & $\mathrm{~g} \mathrm{dm}^{-3}$ & \multicolumn{2}{|c|}{$\mathrm{mg} \mathrm{dm}^{-3}$} & \multicolumn{5}{|c|}{ mmolc $\mathrm{dm}^{-3}$} & \multicolumn{2}{|c|}{$\%$} & \\
\hline $0-30$ & 4,0 & 9,0 & 4 & 10,7 & 1,2 & 5 & 2 & 10 & 34 & 8,2 & 42,2 & 19 \\
\hline $30-60$ & 4,3 & 6,0 & 2 & 5,05 & 0,5 & 3 & 2 & 5 & 20 & 5,5 & 25,5 & 22 \\
\hline
\end{tabular}

Tabela 2. Análise da água coletada na instalação das estruturas experimentais. Piracicaba, SP, ESALQ/USP.

\begin{tabular}{|c|c|c|c|c|c|}
\hline Parâmetro & $\begin{array}{l}\text { Valor } \\
\left(\mathrm{mg} \mathrm{l}^{-1}\right)\end{array}$ & $\begin{array}{l}\text { VMPC } \\
\left(\mathrm{mg} \mathrm{l}^{-1}\right)\end{array}$ & Parâmetro & $\begin{array}{l}\text { valor } \\
\left(\mathrm{mg} \mathrm{l}^{-1}\right)\end{array}$ & $\begin{array}{l}\text { VMPC } \\
\left(\mathrm{mg} \mathrm{l}^{-1}\right)\end{array}$ \\
\hline nitrogênio & 0,60 & & zinco & 0,1 & 5,0 \\
\hline sulfato & 11,80 & $961,0^{*}$ & sódio & 2,7 & $920,0^{*}$ \\
\hline nitrato & 1,80 & $10,0^{*}$ & gás carbônico & 7,1 & 8,7 \\
\hline cloreto & 1,50 & $1050,0^{*}$ & acidez & 11,2 & 18,9 \\
\hline fósforo & 1,03 & $2,0^{*}$ & dureza & 41,6 & 500,0 \\
\hline potássio & 1,60 & $2,0^{*}$ & alcalinidade & 33,0 & \\
\hline cálcio & 7,60 & $400,0^{*}$ & sedimentos & 15,0 & \\
\hline magnésio & 5,50 & $60,7^{*}$ & $\operatorname{cor}^{(1)}$ & 60,0 & 5,0 \\
\hline ferro & 1,00 & 0,3 & turbidez ${ }^{(z)}$ & 23,0 & 1,0 \\
\hline cobre & 9,10 & 1,0 & condutividade $^{(3)}$ & 0,4 & $3,0^{*}$ \\
\hline manganês & n.c & 0,1 & $\mathrm{pH}$ & 6,9 & $6,0-8,5^{*}$ \\
\hline
\end{tabular}

Observação : VMPC -- Valor máximo permitido (água para abastecimento consumo humano);

(1) Ptco; (2) FTU; ${ }^{(3)} \mathrm{mmho} \mathrm{cm}$; *limite máximo indicado para água de irrigação. Fonte: Laboratório de Ecologia Aplicada. ESALQ/USP. 
Após a correção da fertilidade e da acidez do solo de acordo com as recomendações vigentes, conduziu-se a cultura do feijão em caráter exploratório objetivando dar-se um período para a acomodação física e efetiva reação química do solo, utilizá-la como diagnose de deficiências nutricionais remanescentes e, principalmente, para checar a estrutura hidráulica, aferir os instrumentais e adequar a metodologia.

A análise física do solo, realizada após a cultura exploratória (Tabela 3 e 4 e Figura 2) revelou ser um solo bastante arenoso, característica que é muito pertinente à estratégica metodológica do experimento, quanto ao fácil controle do lençol freático. A avaliação da velocidade de movimentação livre do lençol freático no horizonte de 0 a $15 \mathrm{~cm}$ superficicis indicou como tempo de rebaixamento e elevação 15 e 10 minutos, respectivamente.

Tabela 3. Análise granulométrica realizada após o período inicial de estabilização. Piracicaba, SP, ESALQ/USP.

\begin{tabular}{|c|c|c|c|c|c|c|c|c|}
\hline \multicolumn{4}{|c|}{ Areia } & \multirow[t]{2}{*}{ Total } & \multirow{2}{*}{$\begin{array}{l}\text { Silte } \\
(\%)\end{array}$} & \multirow{2}{*}{$\begin{array}{l}\text { Argila } \\
(\%)\end{array}$} & \multirow{2}{*}{$\frac{\text { Floculação }}{\text { total água }}$} & \multirow{2}{*}{$\begin{array}{c}\text { Classe } \\
\text { de textura }\end{array}$} \\
\hline G & M & $F$ & MF & & & & & \\
\hline 1 & 20 & 67 & 4 & 92 & 2 & 6 & 33 & arenosa \\
\hline
\end{tabular}




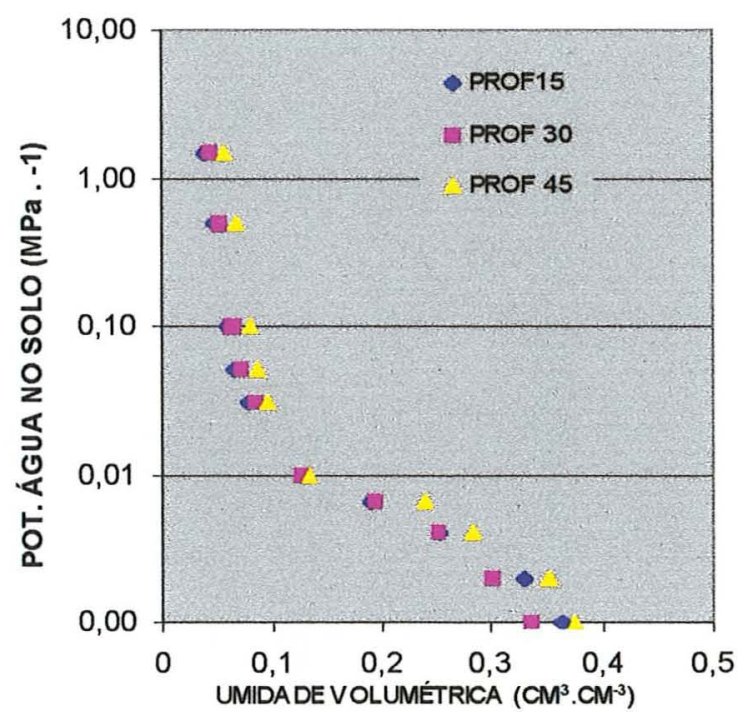

Figura 2 . Curva de retenção de água no solo. Piracicaba, SP, ESALQ/USP.

Tabela 4. Parâmetros físico-hídricos do solo. Piracicaba, SP, ESALQ/USP.

\begin{tabular}{|c|c|c|c|}
\hline \multirow[t]{2}{*}{ Parâmetros } & \multicolumn{3}{|c|}{ Umidade Volumétrica $\left(\mathrm{cm}^{3} \mathrm{~cm}^{-3}\right)$} \\
\hline & Prof $_{15}$ & Prof $_{30}$ & Prof $_{45}$ \\
\hline Saturação do solo $(\Psi=0,001 \mathrm{MPa})$ & 36,3 & 33,7 & 37,3 \\
\hline Capacidade de Campo $(\Psi=0,0066 \mathrm{MPa})$ & 19,0 & 19,5 & 23,9 \\
\hline Limite de variação da água disponível $(\Psi=0,05 \mathrm{MPa})$ & 6,6 & 7,1 & 8,7 \\
\hline Ponto de Murcha Permanente $(\Psi=1.5 \mathrm{MPa})$ & 3,9 & 4,4 & 5,7 \\
\hline Densidade Global $\left(\mathrm{g} \mathrm{cm}^{-3}\right)$ & 1,4 & 1,3 & 1,4 \\
\hline
\end{tabular}




\section{4 - EFEITO DE TRES DIFERENTES MANEJOS DO LENÇOL FREÁTICO NA ADAPTAÇÃO FISIOMORFOLÓGICA DE DUAS ESPÉCIES DE TRIGO (TRITICUM AESTIVUM, L. E TRITICUM DURUM, $L$ ) AO ENCHARCAMENTO.}

Autor: Rinaldo de Oliveira Calheiros Orientador: Prof. Décio Eugênio Cruciani

\section{RESUMO}

Estudou-se o efeito de três manejos do lençol freático na indução de adaptações fisio-morfológicas dos trigos Triticum aestivum $L$. e Triticum durum $L$ à hipoxia, caracterizando e inferindo a influência relativa dos principais fatores físicos e biológicos interferentes. O experimento foi conduzido na ESALQ/USP, Piracicaba, $\mathrm{SP}$, simulando-se o máximo um meio físico/condição natural de uma várzea. Após a indução no período vegetativo através de períodos hipóxicos com duração progressiva, a eficiência dos manejos foi forçada à manifestar-se através de inundação permanente incluindo o florescimento/formação de grãos. Os resultados apontam que o potencial de água na folha foi afetado pela completa submergência da parte subterrânea, já em sua menor duração, não havendo, porém, correspondência com a manifestação fenotípica da cultura; a resposta diferenciada de exigência nutricional e/ou capacidade extração entre as duas espécies sob hipoxia indica que o sucesso produtivo do trigo sob hipoxia pode vir a ser condicionado a estudos específicos sobre suas exigências específicas e, consequentemente, a um plano de fertilização mais ajustado; a adubação foliar não contribuiu para suprir as deficiências nutricionais da planta decorrentes da 
limitação na absorção via sistema radicular, causada pela hipoxia no solo ou, se o fez, foi de forma insuficiente, sugerindo-se estudos específicos; a resistividade estomática mostrou-se o parâmetro de maior sensibilidade na planta de trigo sob encharcamento; os manejos emp:egando curtos períodos de hipoxia induziram adaptações fisiomorfológicas tais que permitiram a sobrevivência das plantas mesmo sob encharcamento contínuo por mais de 50 dias. Essas, porém, não o foram na intensidade ou eficiência que resultassem parâmetros de produção num nível adequado; o manejo do lençol freático mantido a $15 \mathrm{~cm}$ de profundidade durante todo o ciclo fenológico foi o que propiciou melhor performance do trigo; a submergência intermitente mostrou-se altamente prejudicial, com o efeito intensificando-se com o aumento da freqüência da submersão, não sustentando a tese da transmissividade ou acúmulo de induçǒes adaptativas.

Palavras-chave: Drenagem, manejo, hipoxia, tolerância. 
EFFECT OF THREE DIFFERENT WATER TABLE MANAGEMENT ON THE PHYSICAL-MORPHOLOGICAL ADAPTATION OF WHEAT TO FLOODING TOLERANCE.

\section{SUMMARY}

The effect of three different water table management in the physicalmorphological adaptation to flooding tolerance of Triticum aestivum, L. and Triticum durum, $L$. and the relative influence of the main physical and biological factors interfering, were studied and discussed The trial was conducted at ESALQ/USP, Piracicaba, SP, under simulation of a natural low land condition. After induction of hipoxia at vegetative growth stage, the efficiency of management was enforced to show by a short-term waterlogging event at reproductive stage. The minor duration of complete submergence was enough to affect the leaf water potential, despite not having correspondence with phenotiphic manifestations; the different requirements and/or extraction capacities of nutrients between the two species demand specific fertilization studies to reach high levels of productivity; the fertilization on leaves was not enough to avoid nutrition deficits in wheat under hipoxia; the diffusion resistance was the most sensitive parameter; the water table managements used resulted in physical- morphological adaptations but these were not enough to reach adequate biometric parameters of productivity; the permanent water table at $15 \mathrm{~cm}$ management through all the cultural cycle resulted in the best performance; the intermittent inundation were highly detrimental, with its effects seen progressively to the frequency 
of inundation, not sustaining the hypothesis of transmissivity of the inducted adaptations.

Key-words: Drainage, management, hipoxia, tolerance 


\section{1 - INTRODUÇ̃̃O}

Em terras baixas a monocultura é problema mundial (GARRITY \& PERNITO 1996). Nesse contexto, a cultura do trigo poderia desempenhar um papel muito importante como alternativa de sucessão ao arroz, e/ou, principalmente, em rotação. Nessa última função, seu sucesso é altamente desejável para atender extensas áreas que já contam com infra-estrutura de drenagem implantada sob alta inversão de capital na sistematização, que por mal manejo, acham-se comprometidas, definitivamente em muitas, para a orizicultura pela infestação de plantas invasoras - capim arroz e arroz vermelho, principalmente. A recente introdução da espécie de trigo Triticum durum, própria para a confecção de massas, bem como a possibilidade da pronta utilização das máquinas e equipamentos agrícolas sub-utilizados da cultura do arroz o reforçam como uma promissora alternativa para pequenos/médios agricultores de terras baixas.

Mas a sua maior importância ainda pode estar nos estados do sul do país onde nas extensas áreas dos Pampas, a orizicultura participa de um sistema produtivo contando apenas com a bovinocultura, em sistema de utilização rotacionado de terras.

Como característica geral, a diversificação de culturas em terras baixas é fortemente marcada como de alto risco de encharcamento ocasional exigindo a prática da drenagem, normalmente exagerada, que tem levado à degradação do meio. 
Como solução desse impasse surgem os trabalhos de tolerância fisiomorfológica das culturas ao encharcamento (hipoxia/anoxia) cujos resultados são muito variáveis, em função da cultura, cultivar, clima (com reflexos nos processos de trocas gasosas, principalmente a resistência estomática e a transpiração), solo (tipos e velocidades das reações químicas) e manejo da água ao longo do ciclo fenológico.

Dentre as culturas o trigo, como a maior parte das gramíneas, encontra-se em uma condição intermediária de suscetibilidade à hipoxia, sendo, no entanto, uma das mais sensíveis dentre as gramíneas. Segundo WATERS et al., (1991) a baixa tolerância do trigo ao encharcamento pode, dentre outros fatores estar associado com a taxa de fermentação alcóolica a qual é relativamente mais baixa que no arroz, e no milho.

Há uma escassez de estudo do trigo sob encharcamento. O desconhecimento torna-se praticamente total se considerado: para as nossas condições tropicais, conduzida sob condição natural, durante todo o ciclo, com os principais fatores interferentes monitorados.

Para uma planta submetida à condição restrita de oxigênio no solo, a influência do clima é tão grande que os trabalhos, em sua maioria realizados em clima temperado, devem ser interpretados com muito cuidado, dentre outras razões, pela baixa demanda transpirométrica podendo o encharcamento encontrar a planta até mesmo em dormência. Citando diferentes autores, BEARD \& MARTIN (1970), afirmam que forrageiras em dormência ou semi-dormência toleram períodos mais longos de inundação que plantas com desenvolvimento ativo. 
No clima tropical a temperatura exerce uma função determinante na maximização dos efeitos da hipoxia pela velocidade e intensidade das modificações físicas que ocorrem.

Nesse estudo, o monitoramento da taxa de difusão do oxigênio (TDO) e a concentração de $\mathrm{O}_{2}$ no solo é muito importante e tem sido correlacionadas com várias respostas da planta (SOJKA \& SOLTZY, 1980). Como efeitos decorrentes, surgem modificações de natureza física como a penetração das raízes e permeabilidade do solo; nutricionais; químicas - como potencial redox e pH (PONNAMPERUMA, 1984), -; e biológicas, como proliferação de algas e organismos anaeróbicos.

Depois da diferença entre culturas, o comportamento diferenciado entre cultivares é um dos mais importantes. GINKEL et al.. (1992) testaram sob encharcamento 1344 genótipos de trigo, das quais seis linhas produziram entre $1,9 \mathrm{e}$ 2,6 $\mathrm{t} \mathrm{ha}^{-1}$, comparadas com $1,57 \mathrm{t} \mathrm{ha}^{-1}$ da testemunha, Pato, reconhecida como tolerante. Também, sob o aspecto cultural, é amplamente reconhecido que o efeito da aeração é dependente do estádio fenológico da planta (LETEY ET AL., 1961).

Com o comprometimento do sistema radicular, em forma e eficiência, a questão nutricional assume uma importância muito grande na performance final da cultura.

Segundo HUANG et al. (1994) a resposta de diferentes genótipos de trigo tolerantes ao encharcamento ao encharcamento e suplementação de nutrientes raramente tem sido estudada. Trabalhando com duas cultivares de trigo de inverno, submetidas à metade e inteira concentração de nutrientes da solução de Hoagland 
durante 17 dias de encharcamento, iniciado 14 dias após semeadura, observaram redução no potencial de água na folha, condutividade estomática, fotossíntese e conteúdo de clorofila, conteúdo de $\mathrm{N}$ na parte aérea e no desenvolvimento da parte aérea e raízes, em ambas cultivares, porém em níveis diferenciados. Dobrando a concentração de nutrientes aplicado, houve redução na taxa de declínio da fotossintese, conteúdo de clorofila, número de raízes nodais, nível de nitrogênio na parte aérea e na taxa de crescimento, especialmente na cultivar mais suscetível.

No processo de transferência da água no sistema planta/atmosfera, a resistência estomática é um dos principais parâmetros afetados. Trabalhando com trigo, LU (1994) submeteu a cultura a encharcamento de 7 a 33 dias no perfilhamento, emborrachamento e espigamento. O encharcamento reduziu a taxa de condutividade estomática, fotossíntese, transpiração, acúmulo de matéria seca e taxa de emissão de raízes, aumentando o amarelecimento foliar e morte de folhas velhas. Em estádios adiantados causou senescência precoce e decréscimo na produção de grãos.

O estabelecimento abrupto do estado hipóxico não permite aclimatação e/ou a indução de um metabolismo alternativo antes da condição se tornar letal (WADMAN \& VAN ANDEL, 1985). Assim, teoricamente, pode ser factível induzir-se a adaptabilidade físio-morfológica das plantas através de um regime de hipoxia/anoxia específico. $\mathrm{O}$ adequado manejo do lençol freático pode ser a chave para esse processo.

Metabólicamente, o pré-tratamento de plantas de trigo a baixas concentrações de $\mathrm{O}_{2}$ pode aumentar a sua tolerância à anoxia, sendo tais efeitos atribuídos ao aumento nas atividades das enzimas piruvato descarboxilase e álcool dehidrogenase 
(WATERS et al., 1991). Apontam que raízes que tinham sido hipóxicamente prétratadas por $24 h, 90 \%$ retornaram a alongação após 24 hs de anoxia, sendo que houve completa perda da capacidade em plantas que não tinham recebido o prétratamento submetidas a menos de $20 \mathrm{hs}$ de anoxia.

Morfologicamente, o "start" do processo parece estar ligado ao papel dos fitohormônios destacando-se o etileno (SCHAFFER et al., 1992). Esse hormônio pode induzir a epinastia foliar, crescimento de raízes adventícias, hipertrofia dos caules e produção de aerênquima em certas espécies de plantas quando sob encharcamento (BRADFORD \& YANG, 1981; KAWASE, 1981). O aumento da concentração é causado por produção acelerada da planta, decréscimo da difusão da excreção e absorção de etileno produzido por microorganismos.

Um fator químico emitido pelas raízes e transportado pelo xilema promove a produção de etileno na parte aérea das plantas sob encharcamento (JACKSON et al., 1978). Foram identificados como intermediários entre a metionina e o etileno, o SAdenosylmetionina (SAM) e 1-Aminociclopropano-1-acido carboxilico (ACC), sendo que somente o ultimo ocorre sob condições anaeróbicas, exigindo, no entanto, $\mathrm{O}_{2}$ para sua conversão final a etileno.

Estimulada, portanto, pelo etileno, as raízes adventícias tem função de facilitar a absorção de $\mathrm{O}_{2}$ (SENA GOMES \& KOZLOWSKI, 1980b), sendo à elas creditadas uma condutância estomática perto da normalidade em plantas sob encharcamento (SENA GOMES \& KOZLOWSKI, 1980a). 
A habilidade para sua formação é considerada, geralmente, como o maior fator de tolerância da plantas florestais (HOOK \& BROWN, 1973). O uso dessa habilidade como parâmetro indicador de maior adaptabilidade a encharcamento, no entanto, parece só ser útil dentro da mesma espécie, sendo que comparações interespecíficas de tolerância a encharcamento baseado nesse parâmetro são temerosa (SCHAFFER et al., 1992).

Hipertroficmento das lenticelas é caracterizado pelo alargamento celular, uma forma mais esférica e desaparecimento de sua película de fechamento. As lenticelas hipertrofiadas e os arerênquimas funcionam como órgãos de aumento da absorção de $\mathrm{O}_{2}$ e transporte para as raízes, respectivamente (KAWASE, 1981). Este autor atribuiu a formação das duas estruturas mais pela falta de $\mathrm{O}_{2}$ que pela presença da lamina d'água em si, apontando aumento da concentração de etileno nos ramos de plantas encharcadas e conseqüente aumento da atividade da celulase. As lenticelas podem ainda funcionar como depósitos de metabólicos tóxicos (etanol e acetilaldeido) formados sob hipoxia.

Enquanto a formação de espaço de condução de ar em córtex das raízes de arroz é construtiva (não é formada à partir de estímulo), em raízes de trigo esses espaços se desenvolvem em resposta ao encharcamento. É nesse aspecto que a influência do manejo de água se impõem como componente significativo.

Baseado nas considerações acima, há forte evidência de que, num primeiro momento, até mais que a introdução de cultivares mais tolerantes, o adequado manejo 
do lençol freático, pode vir a se constituir na melhor estratégia de exploração de culturas mesófitas em terras baixas.

Teoricamente, um L. F. elevado e estável, imposto logo no início do desenvolvimento vegetativo poderia induzir a planta ao ajuste automático da parte aérea com a, entăo, restrita atividade do sistema radicular. Pesquisa com soja tem mostrado que tal regime pode aumentar de 10 a $20 \%$ a produtividade comparado com a irrigação convencional (NATHANSON et al., 1984).

Já uma aplicação intermitente de períodos curtos de anoxia, exercida através de elevações temporárias do lençol freático acima do nível do solo, conjugada com o lençol estabilizado a $15 \mathrm{~cm}$ no restante do período, poderia induzir a planta à gradativas modificações nos mecanismos adaptativos. Ressalta-se que a resposta, entre as culturas ao encharcamento aplicado de forma intermitente, é tão diferenciado que pode até deixar cle ser fator restritivo para tornar-se benéfico e desejado. É apontado por JOYNER \& SCHAFFER (1989) que árvores de carambola sob encharcamento intermitente por 2,3 ou 6 semanas (com intervalos de 3 semanas entre duas inundações sucessivas) tiveram maior fixação de frutos que as plantas não inundadas.

Ambos os manejos, preparariam as plantas aumentando suas chances de sobreviverem à um súbito evento de anoxia temporal, como por exemplo, uma enchente resultante de uma chuva à montante.

Fica também inquestionável que, nesta natureza de trabalho, pela intensidade, importância relativa e interatividade que desempenham fatores específicos de produção, o perfeito entendimento da performance final do trigo sob hipoxia só é 
permitido se desenvolvido em condições naturais, sob adequada e sistemática caracterização e monitoramento para, à partir daí, procurar interpretar-se as interações decorrentes.

Os objetivos deste trabalho foram:

- Estudar o efeito de diferentes manejos do L. F. nas principais estruturas adaptativas e/ou mitigadoras da hipoxia utilizadas pelo trigo.

- Caracterizar os principais fatores interferentes na produção sob condição de hipoxia e interpretar seu papel individual e interativo na performace final da cultura.

\section{2 - MATERIAL E MÉTODOS}

As análises químicas do solo e da água, amostradas antes do plantio, são apresentadas nas tabelas de 5 a 7.

$\mathrm{Na}$ análise da água, os teores encontrados foram comparados, em parte, com os valores máximos permitidos para consumo humano e, em parte, com os teores máximos permitidos para utilização como água de irrigação.

O plantio foi executado em 17/05/98 utilizando-se o Triticum aestivum, $L$., cultivar IAC 24 a o Triticum durum, L., cultivar IAC 1003, ambas na população de $450 \mathrm{pl} \mathrm{m}^{-2}$ ou $108 \mathrm{pl} \mathrm{m}^{-1}$ linear no espaçamento de $20 \mathrm{~cm}$ entre linhas. 
Tabela 5. Análise química de macronutrientes do solo, anterior ao plantio do trigo na profundidade de 0 a $30 \mathrm{~cm}$. Piracicaba, SP, ESALQ/USP.

\begin{tabular}{|c|c|c|c|c|c|c|c|c|c|c|c|}
\hline $\mathrm{pH}$ & $\mathrm{M} . \mathrm{O}$ & $\mathrm{P}$ & $-\mathrm{SO} 4$ & $\mathrm{~K}$ & $\mathrm{Ca}$ & $\mathrm{Mg}$ & $\mathrm{Al}$ & $\mathrm{H}+\mathrm{Al}$ & SB & $\mathrm{T}$ & $\mathrm{V}$ \\
\hline $\mathrm{CaCl} 2$ & $\mathrm{gdm} \mathrm{m}^{-3}$ & & $m^{-3}$ & & & $\mathrm{mmol}$ & $\mathrm{dm}^{--}$ & & & & $\%$ \\
\hline 4,9 & 8 & 14 & 18 & 0,9 & 15 & 7 & 0 & 25 & 22,9 & 47,9 & 48 \\
\hline
\end{tabular}

Tabela 6. Análise química de micronutrientes do solo, anterior ao plantio do trigo na profundidade de 0 a $30 \mathrm{~cm}$. Piracicaba, SP, ESALQ/USP.

\begin{tabular}{cccccc}
\hline B & $\mathrm{Cu}$ & $\mathrm{Fe}$ & $\mathrm{Mn}$ & $\mathrm{Zn}$ & $\mathrm{Na}$ \\
\hline & \multicolumn{7}{c}{$\mathrm{mg} \mathrm{dm}^{-3}$} \\
0,11 & 0,4 & 55,2 & 1,7 & 2,2 & 20,7
\end{tabular}

Tabela 7. Análise da água coletada. Piracicaba, SP, ESALQ/USP.

\begin{tabular}{|c|c|c|c|c|c|}
\hline Parâmetro & $\begin{array}{l}\text { Valor } \\
\left(\mathrm{mg} \mathrm{P}^{-1}\right)\end{array}$ & $\begin{array}{l}\text { VMPC } \\
\left(\mathrm{mg} \mathrm{l}^{-1}\right)\end{array}$ & Parâmetro & $\begin{array}{l}\text { valor } \\
\left(\mathrm{mg} \mathrm{l}^{-1}\right)\end{array}$ & $\begin{array}{l}\text { VMPC } \\
\left(\mathrm{mg} \mathrm{l}^{-1}\right)\end{array}$ \\
\hline nitrogênio & nc. & & zinco & n.c. & 5,0 \\
\hline sulfato & 0.8 & $961,0^{*}$ & sódio & 0,7 & $920,0^{*}$ \\
\hline nitrato & $\mathrm{nc}$. & $10,0^{*}$ & gás carbônico & 8,7 & \\
\hline cloreto & 1,0 & $1050.0^{*}$ & acidez & 18,9 & \\
\hline fósforo & 0,01 & $2,0^{*}$ & dureza & 52,1 & 500,0 \\
\hline potássio & 0,4 & $2,0^{*}$ & alcalinidade & 36,2 & \\
\hline cálcio & 8,5 & $400,0^{*}$ & sedimentos & 1,7 & \\
\hline magnésio & 7,5 & $60,7^{*}$ & $\operatorname{cor}^{(1)}$ & n.c. & 5,0 \\
\hline ferro & 0.4 & 0,3 & turbidez ${ }^{(2)}$ & 11,0 & 1,0 \\
\hline cobre & n... & 1,0 & condutividade ${ }^{(3)}$ & 0,1 & 3,0 \\
\hline manganês & n.s. & 0,1 & $\mathrm{pH}$ & 6,8 & $6,0-8,5^{*}$ \\
\hline
\end{tabular}

Observação : VMPC - Valor máximo permitido (água para abastecimento consumo humano); n.c. - não consta; ${ }^{(1)} \mathrm{Ptco} ;{ }^{(2)} \mathrm{FTU}$; ${ }^{(3)} \mathrm{mmho} \mathrm{cm}$ * limite máximo indicado para água de irrigação. Fonte: Laboratório de Ecologia Aplicada. ESALQ/USP. 
O cultivar IAC 24 trata-se de um material amplamente utilizado a mais de vinte anos, destinado à panificação, de ótima característica físiomorfológica e boa qualidade de grãos; o cultivar IAC 1003 é um dos primeiros materiais de T. durum primaveris introduzidos no Brasil, destinados à produção de massas finas, sendo ainda muito pouco utilizado pela pesquisa.

O delineamento experimental foi de parcelas subdivididas, inteiramente ao acaso, utilizando-se 4 tratamentos, em 5 repetições. Os tratamentos foram:

$\mathbf{T}_{1}$ - Testemunha;

$\mathbf{T}_{2}$ - Com elevação e manutenção permanente do lençol freático (LF) a $15 \mathrm{~cm}$ de profundidade, até a maturação fisiológica da cultura;

$\mathbf{T}_{3}$ - Elevação e manutenção do $\mathrm{L} \cdot \mathrm{F}$ a $15 \mathrm{~cm}$; aplicação de períodos progressivos de inundação temporária (adaptação induzida) de 2,4 e 24 hs nos intervalos de 15 clias e sequencial aplicação de inundação até a maturação fisiológica da cultura e;

$\mathbf{T}_{4}$ - Idem o $\mathrm{T}_{3}$, com intervalo entre os períodos de inundação de 7 dias.

Durante o estabelecimento, todos os tratamentos, foram conduzidos sob normoxia até o início do perfilhamento, mantendo-se a umidade do solo ao nível da capacidade de campo. Após, os tratamentos foram diferenciados (11 DAE), sendo o $T_{1}$ conduzido, permanentemente em solo aerado, recebendo irrigações subterrâneas, em caráter suplementiar pela elevação do L. F. até a superfície. O "momento da irrigação" foi o potencial hídrico do solo de $0,05 \mathrm{MPa}$, acusado por tensiômetros instalados na 
profundidade estimada correspondente a $50 \%$ do sistema radicular. Rebaixava-se o L. F. imediatamente após. Esse tratamento representou o potencial máximo produtivo relativo da cultura neste solo e clima.

Aos 11 DAE o LF foi elevado a $15 \mathrm{~cm}$ da superfície no $T_{2}, T_{3}$ e $T_{4}$, à exemplo do executado executado por TROUGHT \& DREW (1980). Os períodos progressivos de adaptação induzida constituiram-se da promoção de condições hipóxicas no solo através de elevações temporárias do LF a $1 \mathrm{~cm}$ acima da superfície do solo com seqüencial rebaixamento ao nível de $15 \mathrm{~cm}$.

O teste de adaptação à hipoxia constituiu-se da elevação definitiva do LF à superfície do solo, formando lamina de $1 \mathrm{~cm}$, com rebaixamento completo do $L F$ vindo à ser realizado apenas na maturação fisiológica da cultura.

A análise comparativa entre tratamentos, foi realizada através dos parâmetros biométricos de performance da cultura, incluindo o rendimento de grãos.

A adubaçâo de plantio foi executada com base na análise química. Uma vez que o nitrogênio é sujeito à lixiviação, foi aplicado parceladamente, na forma de uréia buscando minimizar a volatilização do nitrogênio. Esse cuidado foi referendado pelo trabalho de TROUGHT \& DREW (1980) em que a aplicação de uréia aumentou em 40 $\%$ o conteúdo de $\mathrm{N}$ na planta de trigo em comparação com o $\mathrm{NO}_{3}{ }^{-}$.

Assim, a adubação de plantio foi na dosagem de $16 \mathrm{~kg} \mathrm{~N} \mathrm{ha}^{-1}, 80 \mathrm{Kg} \mathrm{P}_{2} \mathrm{O}_{5} \mathrm{ha}^{-1}$ e $80 \mathrm{Kg} \mathrm{K}_{2} \mathrm{O} \mathrm{ha}^{-1}$, alem de $30 \mathrm{Kg} \mathrm{ha}^{-1}$ de FTE (micronutriente). Executando-se, ainda, ao longo do ciclo fenológico, adubações foliares sempre em resposta à sintomas de deficiência nutricional, objetivando minimizar um possível comprometimento no 
processo de absorção via o sistema radicular. A primeira foi realizada aos 36 dias após a emergência $(\mathrm{DAE})$ e a segunda aos 58 DAE. Utilizaram-se dois tipos de adubos foliares. Um deles, fertilizante liquido quelatizado, contendo $8 \%$ de cálcio e $2 \%$ de boro. O outro foi de formulação $14-4-6$, contendo ainda $0,8 \%$ de $\mathrm{S} ; 1,5 \% \mathrm{Mg} ; 2 \%$ $\mathrm{Zn} ; 1,5 \% \mathrm{Mn} ; 0,1 \% \mathrm{~B}$ e $0,05 \%$ Mo. Ambos foram aplicados na dosagem de $31 \mathrm{ha}^{-1}$.

O controle de doenças e pragas foi executado conforme as recomendações vigentes, nada de anormal ocorrendo ao longo do ciclo fenológico da cultura, além de um início de ferrugem na folha e pulgão.

Três horas após o término da primeira PPAI (26 DAE) avaliou-se o potencial de água na folha no T. aestivum utilizando-se bomba de Scholander. Foram utilizadas três planta por repetição.

Para uma análise mais precisa do grau de deficiência nutricional das plantas sob hipoxia realizou-se análise foliar aos $40 \mathrm{DAE}$. A metodologia de amostragem foi a composição de uma amostra única por tratamento, por espécie, coletando-se, de 2 plantas por cultivar, por repetição, 4 folhas por planta, sendo 2 de cima, toda verde, e 2 de baixo, apresentando até $40 \%$ de sua superfície amarelada. As folhas foram coletadas da planta mãe que não a folha bandeira.

Aos 47 DAE avaliou-se a taxa de difusão de oxigênio no solo (TDO) e o potencial redox utilizando aparelho desenvolvido pelo CNPDia/EMBRAPA (HERRMANN et al., 1997).

A avaliaçấo foi realizada em uma parcela do $T_{4}$, antes, durante e nas primeiras horas após o TAH. Para tanto, os eletrodos (em quatro repetições para a TDO), foram 
instalados a $5 \mathrm{~cm}$ de profundidade, elevando-se posteriormente o L. F., num processo de 30 minutos.

Aos $49 \mathrm{DAE}$, correspondente a 2 dias de $\mathrm{TAH}$ no $\mathrm{T}_{4}$ e 9 dias do segundo PPAI ( 4 hs) do $T_{3}$, as alterações hídricas no processo de transferência de água no sistema planta-atmosfera foram avaliadas através da temperatura da folha, umidade relativa, resistência estomática (RE) e da taxa de transpiração, lidas com porômetro de equilíbrio dinâmico (Licor, modelo Li-1600). Metodologicamente, por espécie, foram realizadas leituras em 2 plantas por repetição utilizando-se a folha mais jovem, completamente desenvolvida, no período da manhã, das 8 às $10 \mathrm{hs}$, com as repetições de amostragens sendo efetuadas de modo alternados em relação aos tratamentos, procurando-se eliminar o efeito da elevação gradativa da temperatura do ar ao longo do período de avaliação.

Uma nova leitura dos parâmetros de transferência foi executado aos 52 DAE.

Aos 56 D.AE avaliou-se a taxa de liberação de etileno pelas raízes. Foram coletados ápices das raízes do trigo, no comprimento de $3 \mathrm{~cm}$, numa amostra única por repetição, por espécie e acondicionadas em frasco especial e executada leitura após 2 dias de descanso, utilizando-se o Detector de ionização de chama.

Aos $69 \mathrm{DAE}$, estando o $\mathrm{T}_{4}$ a 22 dias e o $\mathrm{T}_{3}$ a 1 dia de TAH, avaliou-se o LF, quantificando-se o conteúdo de oxigênio dissolvido, $\mathrm{pH}$ e temperatura através do aparelho Aquacheck da Radelkis Eletronical Instruments, realizando-se uma leitura por repetição, entre as 8:00 e 9:45 hs da manhã, a $20 \mathrm{~cm}$ de profundidade da superfície do solo. 
Aos $75 \mathrm{DAE}$, as transformações morfológicas foram caracterizadas, através de observações com lupa da presença de lenticelas e de raízes adventícias.

Executou-se analise química do LF dos três tratamentos hipóxicos, aos 89 DAE, ou seja, aos 21 dias no $T_{3}$ e 47 dias no $T_{4}$ de $T A H$. A amostra composta foi constituída pela contribuição de $1 / 5$ do volume de cada repetição. Os teores encontrados foram comparados, em parte, com os valores máximos permitidos para consumo humano e, em parte, com os teores médios utilizados em solução hidropônica.

Em torno de 120 DAE avaliaram-se os parâmetros biométricos de produção na colheita utilizando 10 plantas por repetição, com exceção do rendimento de grãos, que correspondeu a amostragem em uma fileira central de 1,0 m de comprimento.

As análises estatísticas foram realizadas através da variância $(\mathrm{P}<0,05)$, Teste de significância de Tukey e Duncan, a $5 \%$ e determinação do Erro Padrão.

\section{3 - RESULTAIDOS E DISCUSSÃO}

As análises químicas de macronutrientes e micronutrientes revelaram que o teor de matéria orgânica, o potássio e o fósforo continuaram baixos. $\mathrm{O} \mathrm{Mg}$, apresentando-se na faixa de 5 a 8 , elevou-se à categoria de teor médio.

A calagem executada foi suficiente para elevar de 5 para 15 o teor de cálcio, nivel considerado alto, e, ao mesmo tempo, contribuiu muito discretamente para a elevação do $\mathrm{pH}$. A consideração desse elemento é muito importante pois promove 
maior desenvolvimento do sistema radicular, portanto, teoricamente muito útil na condição de hipoxia em que há restrições físicas. O sulfato elevou-se ainda mais, passando de 10 (alto) para 18 que podemos considerar como muito alto.

A análise de micronutrientes revelou o boro no nível baixo. Esse elemento ativa o transporte de nutrientes, principalmente cálcio das raízes para as folhas e sua falta causa paralisação do crescimento, sérios prejuízos no florescimento, além de favorecer doenças bacterianas. O cobre, a nível de 0,4 , enquadra-se como teor médio. É essencial na fotossíntese, na respiração, na distribuição dos carbohidratos e no metabolismo do nitrogênio, entre cutros.

Já valores acima de 12 para o ferro são tidos como altos. Sendo assim, o nível revelado de 55,2 deve ser considerado como excessivamente alto. Esse elemento é atuante na formação de peróxidos quando da re-oxigenação da planta.

O teor médio do $\mathrm{Mn}$ tende a não causar comprometimento à planta, cuja falta promove redução no sistema radicular, sendo essencial na respiração, fotossíntese, formação de proteínas, sintese hormônios, germinação e maturação. No caso de zinco, se teor maior que 1,2 é tido como alto, portanto 2,2 pode ser considerado muito alto. Sua falta causa encurtamento dos internódios, diminuindo o tamanho das plantas participando da síntese dos hormônios reguladores de crescimento e diferentes reações enzimáticas e metabólicas.

A análise da água de abastecimento revelou ser de água de boa qualidade, sem limitação alguma tanto para utilização no consumo humano como para a prática de irrigação. 
A sequiência de eventos, precipitação e temperatura média, juntamente com a flutuação do L. F. ocorridos durante todo o ciclo fenológico do trigo são apresentados na Figura 3.

Foram executadas 4 irrigações de suplementação no $T_{1}$ ao longo do ciclo fenológico.

Durante o estádio vegetativo, as temperaturas oscilaram em torno de $18{ }^{\circ} \mathrm{C}$, elevando-se, coincidentemente, à partir da implantação do TAH no $T_{4}$, e, ainda mais, na submissão do $\mathrm{T}_{3}$ ao TAH.

O fato das elevações das temperaturas terem ocorrido justamente a partir da implantação dos TAH tornou esse período ainda mais difícil para as plantas uma vez que, neste estádio de intensa atividade metabólica, contando ainda com um sistema radicular pouco efetivo, tinham que satisfazer uma então maximizada demanda transpirométrica (Figura 3A).

A Figura 4 apresenta os resultados da avaliação do potencial de água na folha no T. aestivum.

Observa-se que, não houve significância $(\mathrm{P}<0,05)$ entre o $\mathrm{T}_{1}$ e o $\mathrm{T}_{2}$. Isso pode indicar que, até esse estádio inicial de desenvolvimento da planta, a manutenção do LF constantemente elevado não interferiu no potencial da água na folha, ou seja, por esse parâmetro nẫo foi causado nenhum estresse. Uma vez que neste horizonte esta concentrado, praticamente, todo o sistema radicular do trigo, infere-se, por conseguinte, que este achava-se perfeitamente adaptado à condição hipóxica reinante satisfazendo a necessidade hídrica da planta. 
Por outro lado as duas horas de encharcamento refletiram significativamente $(\mathrm{P}<0,05)$ no potencial da água na folha, diminuindo-o em $15 \%$.

Os resultados obtidos são concordantes com os observados por HUANG et al. (1994) em cultivar de trigo menos tolerante ao encharcamento. Após 17 dias de encharcamento, houve decréscimo de 48 e $27 \%$ no potencial nas plantas conduzidas sob solução contendo metade e toda concentração de nutrientes, respectivamente. Já na cultivar tolerante, nenhuma alteração no potencial foi observada.

Somente o potencial da água na folha parece não ser parâmetro decisivo para atestar estresse hídrico uma vez que, em muitos casos, essa relação não foi confirmada, até mesmo sendo observado efeito contrario, ou seja, um incremento no potencial de água na folhas em condição de anoxia causada por encharcamento (JACKSON et al.,1978). O fenômeno de fechamento estomático desempenha um significante papel em condição hipoxica, mas nesses casos, o sinal para sua ação não é ligado com nenhum decréscimo do potencial de água na planta. PEREIRA \& KOZLOWSKI (1977) afirmam que para muitas espécies, o potencial da água na folha geralmente não declina durante o estágio inicial de encharcamento.

Coerente com as observações acima quanto a possível pouca expressão do potencial de água na folha no estresse hídrico, cinco dias após a primeira PPAI ( 2 hs), tempo suficiente para alguma manifestação física, o aspecto da cultura permaneceu inalterado. Sendo assim, infere-se que a indução inicial executada por um período de duas horas parece ser um aneno começo para uma possivel adaptação gradativa do trigo ao encharcarnento. 

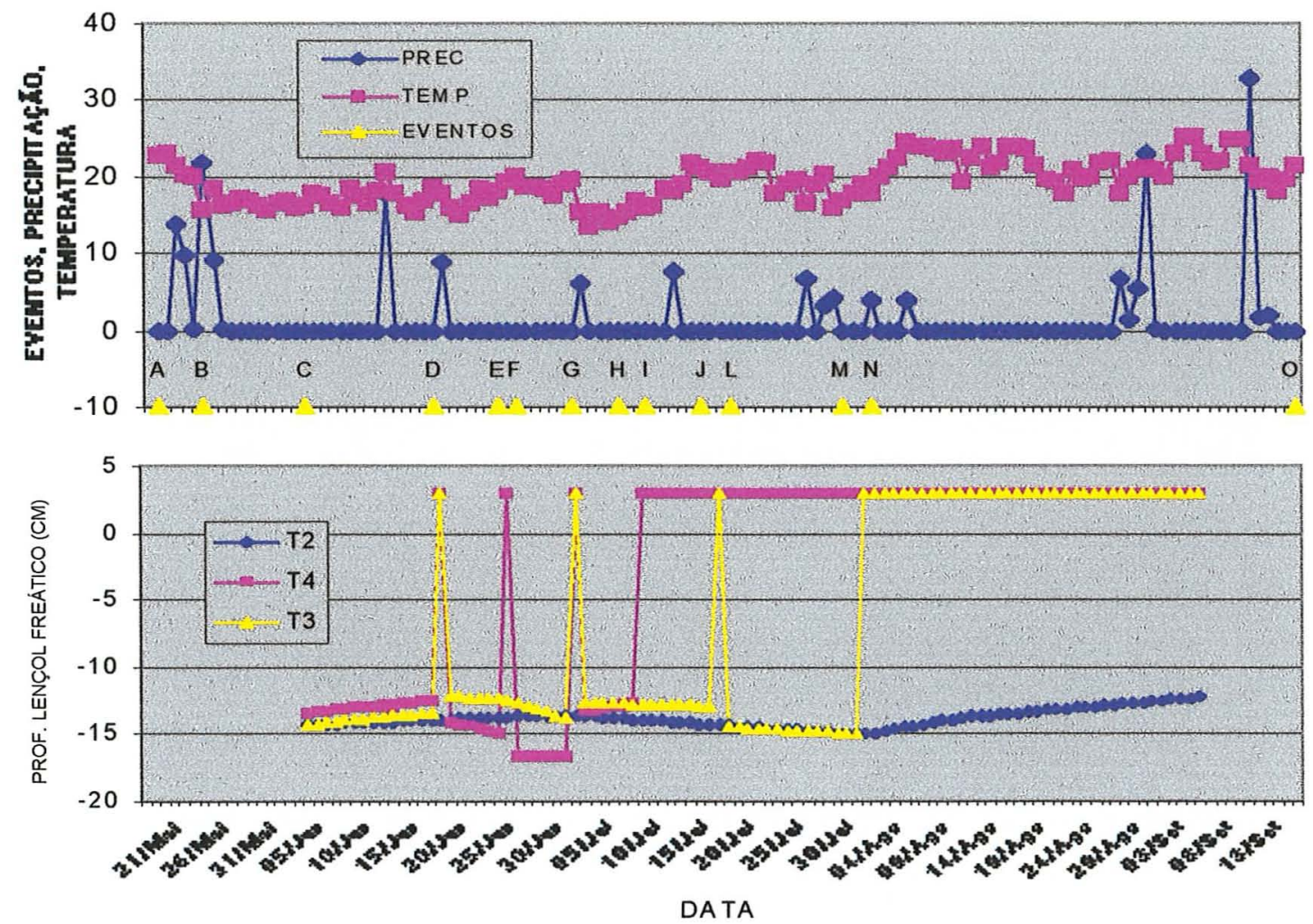

A Plantio;

B 5 DAE, Emergência;

C $11 \mathrm{DAE}$, Elevação LF $15 \mathrm{~cm} ; 12 \mathrm{DAE}$ - Irrigação no $\mathrm{T}_{1}$

DA TA

26 DAE $1^{\text {a }}$ PPAI no $T_{3}$ e $T_{4}$, pls. c/ 4 fol., pleno perfilha/to, alt. pl. $15 \mathrm{~cm}, \mathrm{~s} /$ dif. Fenológica;

E $\quad 33 \mathrm{DAE}^{\mathrm{a}}$ PPAI no $\mathrm{T}_{4}$;

F 35 DAE, Primeiros sintomas hipóxicos, amareleci/to fol. de baixo (FBA) no T3 e $\mathrm{T}_{4}$; irrigação no $T_{1}-36 \mathrm{DAE}, 1$ pulverização foliar;

40 DAE, $3^{\text {a }}$ PPAI no $\mathrm{T}_{4}, 2^{\text {a }}$ PPAI no $\mathrm{T}_{3}$ - clorose somente no $\mathrm{T}_{4},-43 \mathrm{DAE}, 30$ a $50 \%$ das plantas com FBA nos $\mathrm{T}_{3}$ e $\mathrm{T}_{4}$, clorose no $\mathrm{T}_{3} ; \mathrm{T}_{2} \mathrm{~s} / \mathrm{FBA}$, com ligeira clorose;

46 DAE, T. aestivum o/ fol. bandeira estendida, estádio início do emborracha/to em todos trata/tos; $T$. durum no final da alongação/início do emborrachamento; no $\mathrm{T}_{4} T$. aestivum $\mathrm{c} / 30-40 \mathrm{~cm}$ e

T. durum $\mathrm{c} / 25 / 30 \mathrm{~cm}$ de altura; - $47 \mathrm{DAE}$, inicio TAH no $\mathrm{T}_{4}$;

I $49 \mathrm{DAE}, \mathrm{T}_{2} \mathrm{c}$ clorose, porém $\mathrm{c} /$ menor sintoma de hipoxia que $\mathrm{T}_{3}$ e $\mathrm{T}_{4}$, sem dif. De sintoma de hipoxia entre cvs. em qquer trata/to;

J $\quad 55 \mathrm{DAE}, 3^{\circ}$ PPAI no $\mathrm{T}_{3}$;

$\mathrm{L} \quad 58 \mathrm{DAE}, 2^{\mathrm{a}}$ pulver. foliar; irrigação do $\mathrm{T}_{1}$;

M $68 \mathrm{DAE}$, - inicio $\mathrm{TAH}$ no $\mathrm{T}_{3} ; \mathrm{T}_{4}$ a 21 dias de $\mathrm{TAH}$;

$\mathrm{N} \quad 73$ DAE, - Espigamento (\%) do T. aestivum e T. durum, respectiva/te: $\mathrm{T}_{1}$ - as duas cvs. $100 \% ; \mathrm{T}_{2}$ $90 \%$ e $5 \%, \mathrm{~T}_{3}-80 \%$ e $5 \% ; \mathrm{T}_{4}-50 \%$, e $2 \%$; no $\mathrm{T}_{4}$ o T. aestivum sentindo muito, apresentando algumas pls. secas, as demais condições (cultivar e tratamento) c/ bom desenv/to; as duas cvs, em todos trata/tos, c/ fols. de cima verdes e as de baixa secas. - $80 \mathrm{DAE}$ irrigação do $\mathrm{T}_{1}$;

O 119 DAE, - colheita.

Figura 3. (A) Seqüência de eventos, precipitação $(\mathrm{mm})$ e temperatura média $\left({ }^{\circ} \mathrm{C}\right)$ e $(\mathrm{B})$ flutuação do L. F. ocorridos durante o ciclo fenológico. Piracicaba, SP, ESALQ/USP. 


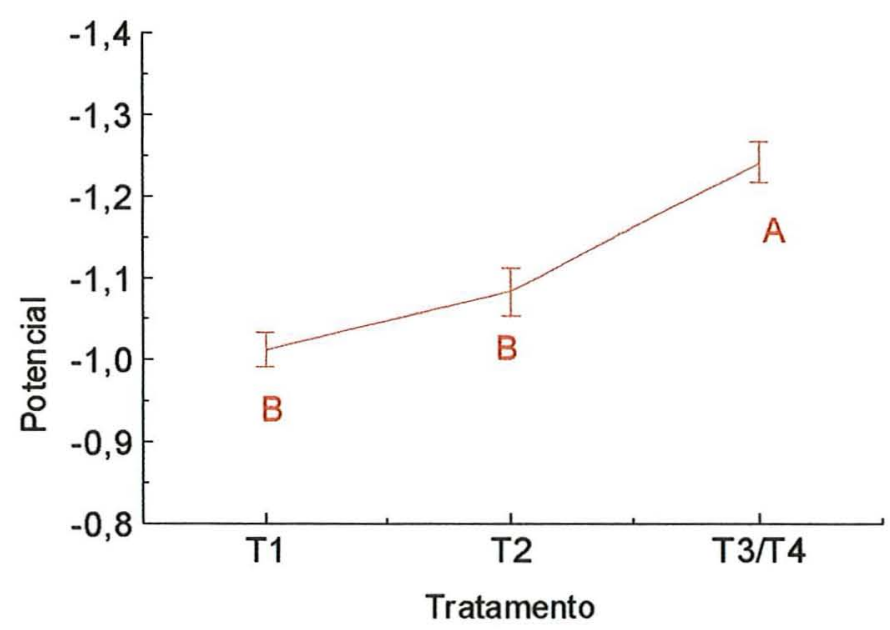

Figura 4. Potencial da água na folha (MPa $10^{-1}$ ) no T. aestivum, amostrado 3 horas após a primeira PPAI. Piracicaba, SP, ESALQ/USP. Médias seguidas de mesma letra não diferem entre si, Duncan $5 \%, n=15$.

Ressalta-se que esse tempo inicial de encharcamento é importante porque pode vir a comprometer irreversivelmente a performance da planta.

Tem sido observado com algodão e soja (HUCK, 1970) que condições de anoxia paralisa o crescimento das raízes inteiramente dentro de 2 a 3 minutos. Quando o estresse não prolongou-se por mais que 30 minutos a taxa subsequente de crescimento retornou ao normal. Anoxia por mais de 3 horas para algodão e 5 horas para a soja matou o ápice das raízes.

Já aos 35 DAE, os primeiros efeitos da hipoxia através do amarelecimento das folhas de baixo, pelo fato de ter ocorrido em iguais intensidade, no $T_{3}$ e no $T_{4}$ e não ter se manifestado no $T_{2}$ deve ser interpretado mais como efeito da prática do período curto de encharcamento, conjugado com o lençol elevado a $15 \mathrm{~cm}$ do que pela 
intensidade das $\mathrm{PPAI}_{\mathrm{s}}$ ministradas. Dentro de uma gama de possibilidades, pode-se inferir que, com o aumento da evapotranspiração da cultura a medida que a planta foi se desenvolvendo, o sistema radicular, mais fortemente afetado pela PPAI e já subdesenvolvido e limitado pela barreira do LF presente a $15 \mathrm{~cm}$ de profundidade, não conseguiu supri-la convenientemente. Isso foi agravado ainda mais, proporcionalmente, com o aumento da temperatura então na faixa de $20{ }^{\circ} \mathrm{C}$, atipicamente alta para esta época do ano. Dentro da opção da indução adaptativa através de períodos de submergência, talvez a mais prática e efetiva solução estratégica para esse problema seria tentar promover a adaptação morfológica do sistema radicular à hipoxia proporcionalmente com a velocidade do aumento da demanda evapotranspirométrica. Os sintomas hipóxicos relatados mostram que isso não ocorreu. Talvez isso possa ser conseguido através da elevação gradativa do LF ao invés de curtos e intermitentes períodos hipóxicos, como o empregado.

Os aspectos nutricionais também devem ser considerados, sendo que o amarelecimento das folhas de baixo motivou a realização da primeira pulverização de adubo foliar aos 36 DAE.

Aos $41 \mathrm{DAE}, \mathrm{o} \mathrm{T}_{4}$, no final das 24 horas sob encharcamento, além das folhas de baixo já amareladas, as duas cultivares apresentavam clorose. O mesmo não foi observado no $\mathrm{T}_{3}$ que, por essa ocasião ainda recebia a segunda PPAI (4 horas), vindo, porém a manifestar aos $43 \mathrm{DAE}$ enquanto o $T_{2}$ mantinha-se ainda sem sintoma hipóxico, com exceęão de uma ligeira clorose. 
Além do efeito da deficiência hídrica acima discutida a deficiência nutricional passou a ser uma hipótese preocupante levando-se à hipótese de que talvez a aplicação de adubo foliar tivesse sido deficiente.

Deve ser atentado que por ocasião da análise foliar, aos $43 \mathrm{DAE}$, até então o $\mathrm{T}_{2}$ esteve permanentemente com o LF a $15 \mathrm{~cm}$, o $\mathrm{T}_{3}$ recebido as duas $\mathrm{PPAI}_{\mathrm{s}}$, de 2 e $4 \mathrm{hs}$, e o $\mathrm{T}_{4}$ as três, de 2,4 e 24 hs, estando ambas a 5 dias da ultima.

A Figura 5 mostra os resultados da análise foliar.

Pela análise foliar (Figura 5), em relação ao nitrogênio, ao potássio, fósforo e ao enxofre, nas cluas espécies, e no Ca no $T$. durum observa-se uma tendência ao decréscimo gradativo dos teores com a intensidade de inundação. A proximidade dos valores entre o $T_{3}$ e o $T_{4}$ nos três primeiros elementos indica que mesmos os $\mathrm{PPAI}_{\mathrm{s}}$ ao nível de 2 e 4 hs, no intervalo de 15 dias, já foram suficientes para limitar a presença do $N$ na folha.

Além da limitação na capacidade de extração do nutriente do solo, a lixiviação do $\mathrm{N}$ pode ter resultado essa deficiência nutricional.

Os resultados são coerentes com os aspectos físicos observados, mais discretos no $T_{2}$ e mais evidentes no $T_{3}$ e $T_{4}$. Como os níveis de $\mathrm{K}$ encontrados no $T$. durum foram, na média dos tratamentos e no $\mathrm{T}_{1} 30 \%$ maior que no $T$. aestivum e o de $\mathrm{P}$ e Ca quase o dobro, pode-se concluir que o $T$. durum é mais extrativo ou exigente nesses elementos que o T. aestivum. Segundo GLINSKI \& STEPNIEWSKI (1986), a anoxia causa um decréscimo no conteúdo de potássio em todas as partes da planta. Afirmam que, no trigo, o encharcamento inibe completamente a sua absorção com o 
deslocamento do autriente das folhas velhas para as jovens, percebível após 2 dias de encharcamento. Apontam que a deficiência em potássio é o sintoma mais sensível ao encharcamento, visto primeiro e mais distintamente que no caso dos outros íons.

Apenas no $T$. durum o teor de fósforo elevou-se do $T_{1}$ para o $T_{2}$ como que favorecido pelo maior conteúdo de umidade do solo, decrescendo abruptamente e proporcionalmente com a intensidade de inundações periódicas. Um decréscimo da retirada de fósforo pelo trigo sob encharcamento é apontado por LABANAUSKA et al., 1975. Segundo GLINSKI \& STEPIEWSKI (1986), um decréscimo de fósforo na planta aparece após a concentração de oxigênio cair abaixo de $0,05 \mathrm{~m}^{3} \cdot \mathrm{m}^{-3}$. Segundo TROUGHT \& DREW (1980) quando raizes de trigo foram submersas, a retirada de fósforo foi quase completamente paralisada, à despeito das plantas continuarem seu crescimento mais lentamente. Como resultado, após 2 dias de encharcamento o decréscimo no conteúdo de fósforo torna-se evidente nas folhas velhas, enquanto as jovens apresentam acréscimo. Após 2 semanas de encharcamento mais de $80 \%$ do fósforo já é deslocado das folhas velhas para as jovens. Essas observações são coerentes com o decréscimo do conteúdo de fósforo obtidos nesse trabalho. É importante enfatizar que a translocação dos nutrientes $\mathrm{N}, \mathrm{P}$ e $\mathrm{K}$ das folhas de baixo para as de cima, induzida pela hipoxia, referenda o acerto na metodologia de coleta utilizada - $50 \%$ de folhas velhas, de baixo e $50 \%$ de folhas novas, de cima.

O teor de Ca no $T$. aestivum, apresentou uma tendência de elevação gradativa com a hipoxia. LETEY et al. (1961), afirmam que o conteúdo de cálcio, assim como o do magnésio nas plantas, parece ser menos dependente da anoxia que o nitrogênio, 
potássio e fósforo. De acordo com TROUGHT \& DREW (1980), o trigo não manifesta nenhuma tendência ao deslocamento desses dois elementos das folhas velhas para as novas. Além disso, os resultados acima são concordantes com os observados por LETEY et al., 1961 que apontam para diferentes culturas, que a redução no acúmulo causado pela limitação de oxigeno no solo é na ordem de $\mathrm{K}>\mathrm{P}>$ $(\mathrm{Ca}+\mathrm{Mg})$.

Voltando-se novamente às curvas, nota-se que, com exceção dos níveis atingidos noT $T_{2}$ pelo $T$. durum há uma tendência nas duas espécies, à exemplo do observado com o Mg, à pouca modificação dos teores, o que agora sim, colocaria o comportamento desses trigos em nossas condições, em coerência com a literatura. Trabalhos futuros poderão elucidar melhor esse comportamento.

Diferentemente de outros macronutrientes, os valores de $\mathrm{Mg}$ encontrados no $\mathrm{T}$. durum foram muito próximos dos T. aestivum, parecendo demostrar que para essas duas espécies não há diferença na capacidade de extração e/ou exigência nutricional, reforçando também a coerência dos resultados com os obtidos por outros autores.

Já em releção aos micronutrientes, no $T$. durum, o $\mathrm{Mn}$, o $\mathrm{Zn}$, o $\mathrm{B}$ e o $\mathrm{Cu}$ apresentaram uma resposta negativa nítida em relação a intensidade de encharcamento. No T. aestivum, evidencia-se uma elevação brusca nos teores de B e Mn do $T_{3}$ para o $T_{4}$, contrariando uma tendência de decréscimo com o grau de hipoxia. Não se tem uma explicação para tal.

Excetuando-se, portanto, o T4, , no T. aestivum, um acentuado decréscimo com a hipoxia foi observado somente para o $\mathrm{B}$, havendo, em quase todos os outros, apenas 
discreta tendência de acréscimo ou decrécimo ou mesmo não responsividade, o que estaria parcialmente em concordância com o apresentado por GLINSKI \& STEPIEWSKI (1986), que de todos os micronutrientes, somente o manganês apresenta uma tendência geral de decrescer seu teor nas folhas e elevar nas raizes.

No $\mathrm{Mn}$, considerando-se os valores de $T_{1}$ e da média dos tratamentos (excetuando-se $o T_{4}$ ) verifica-se que no $T$. aestivum seu teor foi de $62,8 \%$ em relação ao T. durum, inferindo-se ser este ultimo mais exigente/extrativo nesse elemento.

No $\mathrm{Cu}$ (excetuando-se o $\mathrm{T}_{4}$ do $T$. durum) no $\mathrm{Fe}$ e no $\mathrm{B}$, tanto a média dos tratamentos como os teores do $T_{1}$ apontam para a mesma exigência ou extração desses micronutrientes nas duas espécies.

O ferro, nas duas espécies, apresentou exatamente o comportamento esperado em resposta ao encharcamento ou seja, embora discreto, um acréscimo gradativo, do teor com o grau de intensidade de inundações.

Infere-se ter isso sido causado pela intensidade de redução do $\mathrm{Fe}$ e sua maior disponibilidade no solo. Esse comportamento seria compatível ao do arroz.

Segundo GLINSKI \& STEPIEWSKI (1986), essa gramínea, que é bem adaptada ao encharcamento, mostra um aumento em ferro nessas condições.

Por outro lado, um acumulo excessivo sob encharcamento pode trazer danos ao tecido através da produção de radicais ativos (CRAWFORD \& BRAENDLE, 1996).

No T. aestivum o zinco apresentou uma tendência de não responsividade com o encharcamento, diferenciando-se apenas no $T_{4}$. 
A tendência de decréscimo no teor de $\mathrm{Zn}$ com a hipoxia apresenta pelo $T$. durum é coerente com o observado em trigo por LABANAUSKAS et al. (1975).

Como consideração geral, a tendência do $T$. durum de apresentar maiores teores de macronutrientes na folha, com exceção do nitrogênio e do manganês, pode indicar, uma maior adaptação do seu sistema radicular à hipoxia e/ou que é mais exigente que o T. aestivum, o que então mereceria uma adubação diferenciada.

A diferenciação entre cultivares de trigo sob encharcamento no teor de nutriente na planta também foi observado por HUANG et al. (1994), atribuindo a isso a maior e mais efisiente absorção da cultivar tolerante que a suscetível.

Por outro lado, pode-se também concluir-se que a adubação foliar executada não atingiu o objetivo proposto ou se contribuiu, o fez de forma insuficiente para suprir as deficiências nutricionais da planta causada pelo comprometimento da via radicular.

Dado à importância do fator nutricional para se alcançar sucesso na cultura do trigo sob encharcamento, sugere-se que estudos específicos sobre adubação foliar sejam realizados.

Fenológicamente, o T. durum aos 46 DAE estava um pouco mais atrasado, porte baixo $(25-30 \mathrm{~cm})$, porém sem diferença do quanto ao sintoma de hipoxia nos tratamentos hipóxicos do T. aestivum (Figura 6).

Pode-se inferir que o fato de ter sido submetido à $\mathrm{PPAI}_{\mathrm{s}}$ num estádio ligeiramente mais jovem não implicou em diferença de resposta à hipoxia. 
A mesma diferença de desenvolvimento estava na testemunha, reforçando, portanto, que até Łsta data a diferença vegetativa era meramente genética.

No $T_{4}$, aos 47 DAE, na aplicação do TAH, o LF estava inicialmente a $13 \mathrm{~cm}$. A variação da taxa de difusão de oxigênio -TDO e do potencial redox ao longo do período de elevação, são mostradas na Figura 6.

É amplamente conhecido que o melhor indicador de disponibilidade de oxigênio do solo prara a planta é a TDO.

Segundo GLINSKI \& STEPIEWSKI (1986) o valor da TDO no solo varia, mais freqüentemente, dentro da faixa de 0 a $120\left(\mathrm{~g} \mathrm{~cm}^{-2} \min ^{-1} 10^{-8}\right)$. 

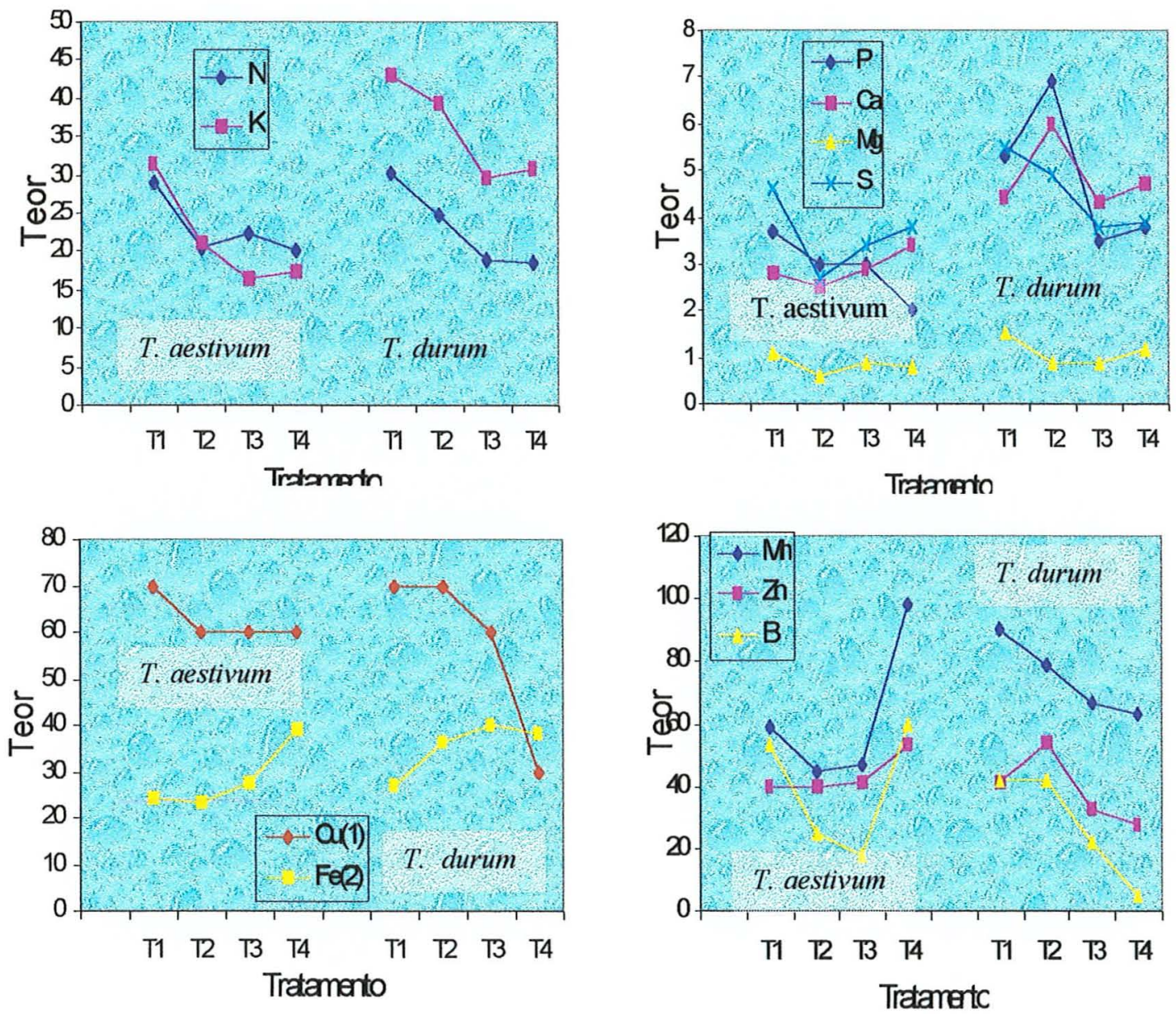

Figura 5. Análise foliar de macro $\left(\mathrm{g}^{\mathrm{kg}} \mathrm{kg}^{-1} \mathrm{~m} \mathrm{~s}\right)$ e micronutrientes $\left(\mathrm{mg} \mathrm{kg}^{-1} \mathrm{~m} \mathrm{~s}\right)$ do $T$.

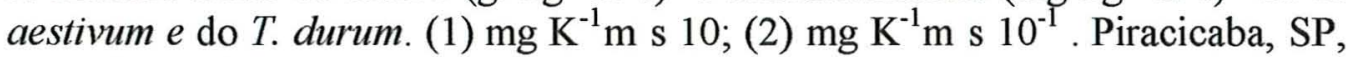
ESALQ/USP. 


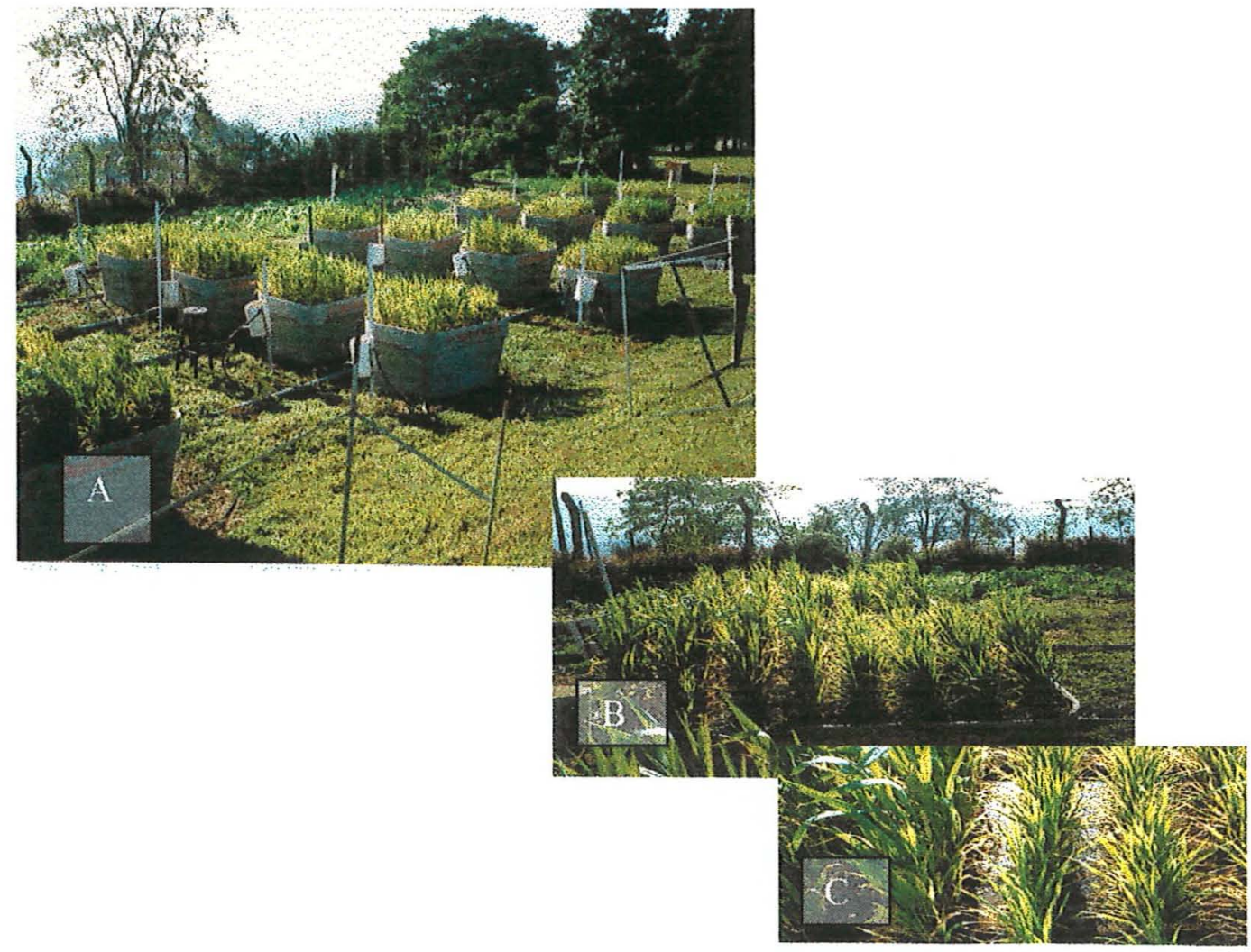

Figura 6. Desenvolvimento fenológico das duas espécies de trigo, quando da aplicação do TAH no $\mathrm{T}_{4}$. (A) Vista geral do experimento; (B) Diferença fenológica entre as duas espécies, à esquerda - T. aestivum, à direita - $T$. durum; (C) detalhe da lâmina de inundação. Piracicaba, SP, ESALQ/USP. 
Estudando o efeito da TDO na densidade de raízes de trigo, SILVERBUSH et al. (1979) apontam que a densidade de raízes começa a reduzir-se a uma TDO de $30 \mathrm{~g}$ $\mathrm{cm}^{-2} \min ^{-1} 10^{-8}$ e cai abruptamente para menos de $1 / 5$ do numero original no intervalo de 30 a $24 \mathrm{~g} \mathrm{~cm}^{-2} \mathrm{~min}^{-1} 10^{-8}$. $\mathrm{O}$ valor de $24 \mathrm{~g} \mathrm{~cm}^{-2} \min ^{-1} 10^{-8}$ pode ser aceito como critico e $30 \mathrm{~g} \mathrm{~cm}^{-2} \mathrm{~min}^{-1} 10^{-8}$ como limite para o desenvolvimento da raiz do trigo.
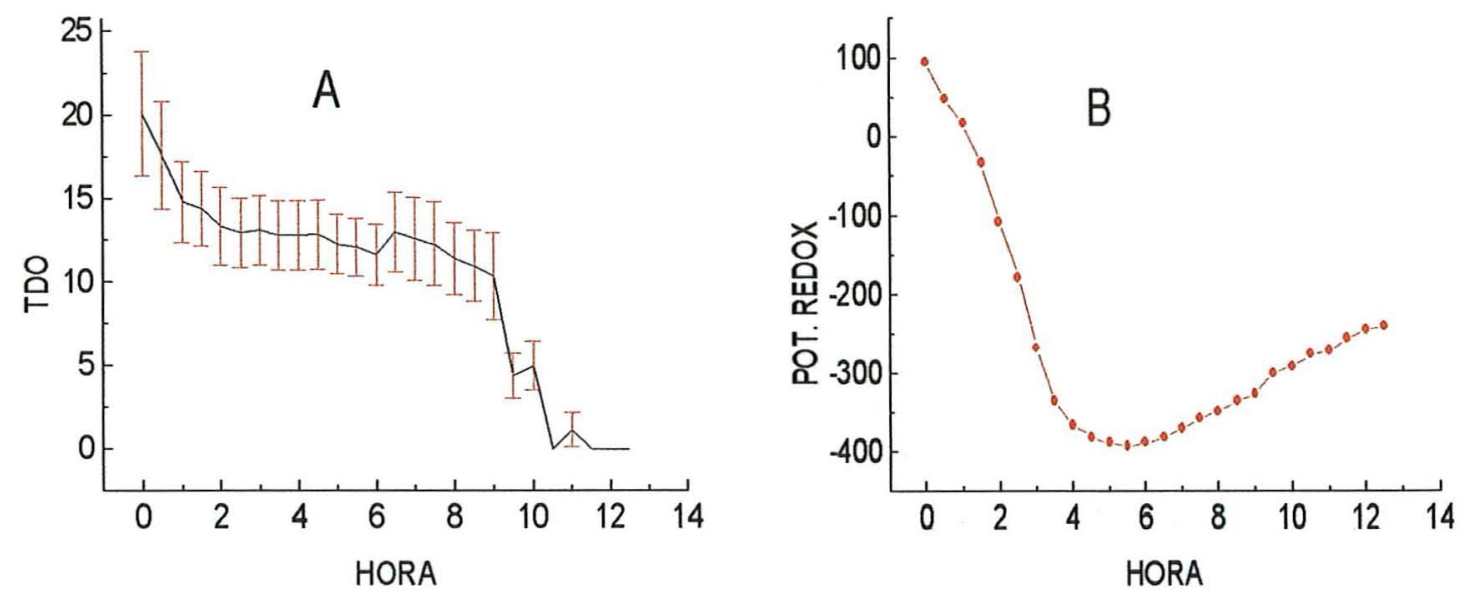

Figura 7. (A) Variação da taxa de difusão de oxigênio $\left(\mathrm{g} \mathrm{cm}^{-2} \min ^{-1} 10^{-8}\right)$ com média e erro padrão, $n=4$ e; (B) Variação do potencial redox $(\mathrm{mV})$ durante a elevação do L. F. no TAH do T4. Piracicaba, SP, ESALQ/USP.

Concordante, STOLZY \& LETEY (1964) citando diversos autores, apontam o valor de $20 \mathrm{~g} \mathrm{~cm}^{-2} \mathrm{~min}^{-1} 10^{-8}$ como limite para o crescimento do sistema radicular. 
Observa-se que, a $5 \mathrm{~cm}$ de profundidade, até mesmo anterior à elevação do LF, a TDO já encontrava-se num valor abaixo do crítico ao desenvolvimento das raízes do trigo indicado pela literatura, atribuindo-se essa condição à franja capilar.

Essa condição crítica fica ainda mais evidenciada se considerado que para plantas que se desenvolvem em condições naturais de áreas úmidas, portanto, teoricamente, perfeitamente adaptadas á hipoxia, os limites de hipoxia foram apontados para una TDO entre 5 a $25 \cdot 10^{-8} \mathrm{~g} \cdot \mathrm{cm}^{-2} \cdot \mathrm{min}^{-1}$ (POEL, 1960). Essa condição altamente restritiva explica o comportamento nutricional da planta anteriormente discutido, bem como todas as inferências do comprometimento do sistema radicular. STOLZY \& LETEY (1964), relacionando a TDO com a nutrição da planta, citam que sob valores abaixo de uma TDO de 30 a $40.10^{-8} \mathrm{~g} \mathrm{~cm}^{-2} \mathrm{~min}^{-1}$, houve apenas ligeiros aumentos na concentração de K e P no girassol. Apontam também que com Citrus sinensis, a concentração de $\mathrm{P}, \mathrm{K}, \mathrm{Ca}, \mathrm{Mg}, \mathrm{Fe}, \mathrm{Mn}$ e $\mathrm{B}$ foram reduzidos à taxas abaixo de $33.10^{-8} \mathrm{~g} \cdot \mathrm{cm}^{-2} \min ^{-1}$, comparadas com as concentrações de plantas desenvolvendose em TDO acima de $62.10^{-8} \mathrm{~g} \mathrm{~cm}^{-2} \mathrm{~min}^{-1}$.

O decréscimo do potencial redox, foi mais brusco que a TDO, e após ter atingido um ponto mínimo, elevou-se, gradativamente, atingindo um ponto intermediário $(-240 \mathrm{mV})$ após 12,5 hs (Figura 7B). 
Tabela 8. Análise de variância e coeficiente de variação (\%) dos parâmetros de transferencia de água. Piracicaba, SP, ESALQ/USP.

$\begin{array}{lccccc}\text { Espécie } & \text { Aval. } & \text { Temp. } & \text { UR } & \text { RE } & \text { Transp. } \\ & & & & & \\ \text { T. aestivum } & 49 & 8,7^{*}(2,6)^{(1)} & 2,4^{\text {ns }}(4,0) & 1,7^{\text {ns }}(18,9) & 8,9^{*}(4,6) \\ & 52 & 21,1^{*}(3,8) & 54,1^{*}(2,6) & 17,8^{*}(14,3) & 0,9^{\text {ns }}(7.8) \\ & & & & & \\ \text { T. durum } & 49 & 1,5^{\text {ns }}(2,2) & 9,3^{*}(2,0) & 0,3^{\text {ns }}(16,0) & 1,4^{\text {ns }}(3,2) \\ & 52 & 15,9^{*}(4,4) & 4,4^{*}(6,0) & 14,4^{*}(12,3) & 1,2^{\text {ns }}(4,0)\end{array}$

Significância estatística $(\mathrm{P}<0,05) ; \quad\left(^{*}\right)$ significativo a $5 \% ;\left({ }^{\text {ns }}\right)$ não significativo. (1) Coeficiente de variação.

Os resultados da avaliação dos parâmetros de transferência da água no sistema solo/ atmosfera do $T_{4}$ em relação ao $T_{2}$ e $T_{1}$, realizada aos $49 \mathrm{DAE}$, são apresentados nas Figuras 8 e 9, para o T. aestivum e o T. durum, respectivamente. A análise estatística é apontada na Tabela 8 . Em relação aos eventos, o $T_{1}$ teria recebido 2 irrigações e o $T_{4}$ já estaria com 2 dias de TAH. Fenológicamente, o T. aestivum estava com a folha bandeira totalmente estendida e em pleno emborrachamento e o T. durum no final da alongação / início do emborrachamento.

Na primeira avaliação do T. aestivum, aos 49 DAE, observa-se que a UR\% apresentou-se ligeiramente menor no $\mathrm{T}_{2} \mathrm{e} \mathrm{T}_{4}$, porém sem significância $(\mathrm{P}<0,05)$. A temperatura da folha seguiu o mesmo comportamento da UR, diminuindo com a intensidade de hipoxia, com diferença significativa $(P<0,05)$ do $T_{1}$ em relação ao $T_{2} e$ $T_{4}$. Essa maior temperatura da folha do $T_{1}$, bem como a tendência de diminuição com o grau de hipoxia, no entanto, teve correspondência inversamente proporcional com a taxa transpirométrica. Essa correspondência negativa deve-se, teoricamente, ao fato da 
planta, sob condições restritas para efetuar trocas gasosas com a atmosfera tem dificuldade em manter suatemperatura foliar ao nível adéquado, elevando-a: Concorre
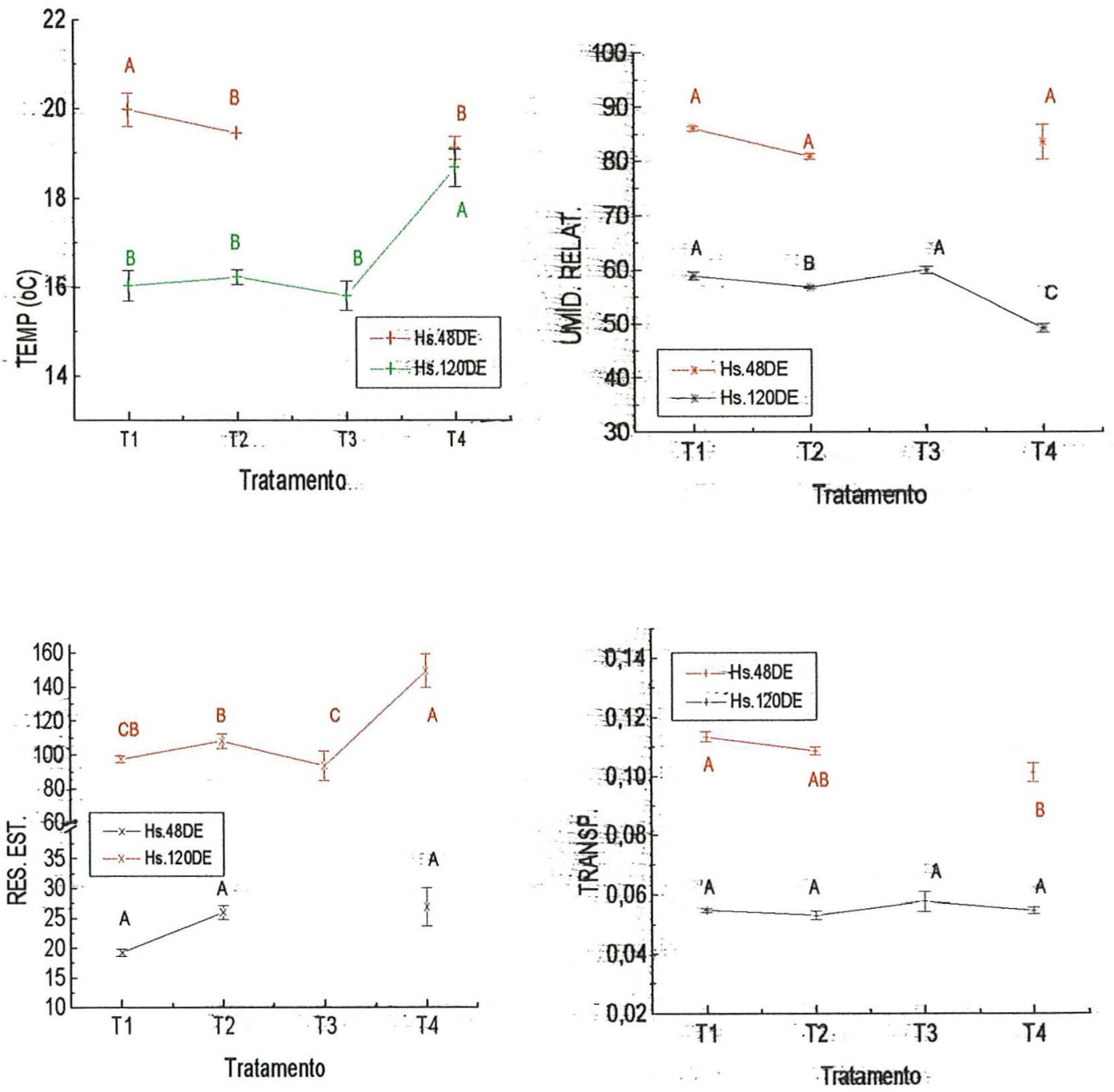

Figura 8. Avaliação aos $49 \mathrm{DAE}$ (48 hs de TAH) e $52 \mathrm{DAE}$ (120 hs de TAH) dos processos de transferencia de água no T. aestivum. Temperatura $\left({ }^{\circ} \mathrm{C}\right)$; Umidade relativa (\%); Resistência Estomática $\left(\mathrm{s} \mathrm{cm}^{-1}\right)$ e Transpiração $\left(\mu \mathrm{g} \mathrm{cm}^{-2} \mathrm{~s}^{-1}\right)$. Médias seguidas de mesma letra não diferem entre si, Duncan 5\%; média e erro padrão $n=10$. Piracicaba, SP, ESALQ/USP. 

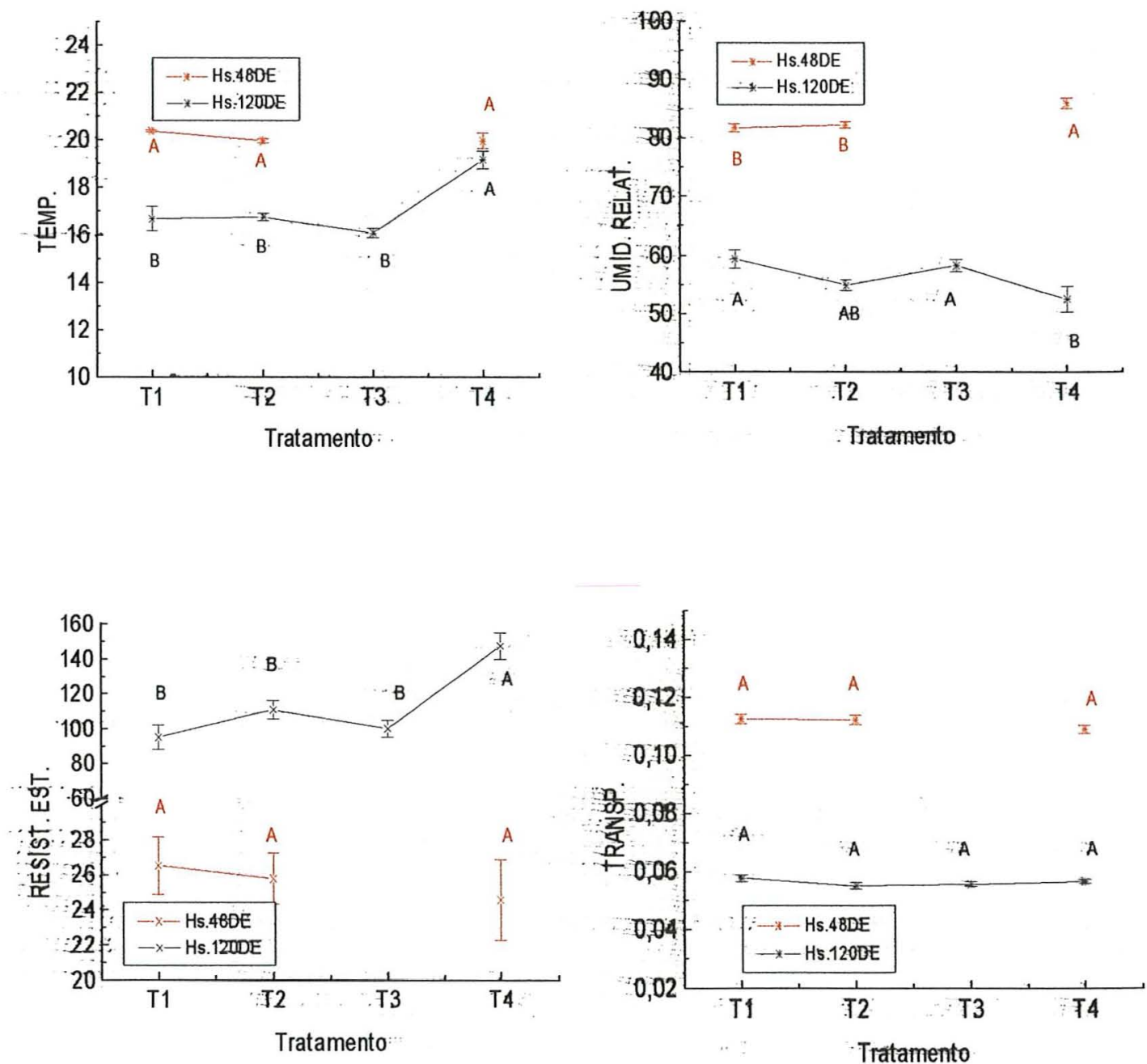

Figura 9. Avaliação aos $49 \mathrm{DAE}$ (48 hs de TAH) e $52 \mathrm{DAE}$ (120 hs de TAH) dos processos de transferencia de água no $T$. durum. Temperatura $\left({ }^{\circ} \mathrm{C}\right)$ Umidade relativa (\%); Resistência Estomática $\left(\mathrm{s} \mathrm{cm}^{-1}\right)$ e Transpiração $\left(\mu \mathrm{g} \mathrm{cm}^{-2} \mathrm{~s}^{-1}\right)$. Médias seguidas de mesma letra não diferem entre si, Duncan $5 \%$; média e erro padrão $n=10$. Piracicaba, SP, ESALQ/USP. 
para isso tanto a menor evaporação da água como também o menor conteúdo de água na folha (diagnosticado pelo menor potencial de água na folha, discutido anteriormente). Concordante com o esperado, a taxa de transpiração da planta sofreu um decréscimo com a intensidade de encharcamento, passando de 0,113 no $T_{1}$ para 0,109 no $T_{2}$ e $0,102\left(\mu \mathrm{g} \mathrm{cm}^{-2} \mathrm{~s}^{-1}\right)$ no $\mathrm{T}_{4}$, apresentando uma amplitude de variação total de $10 \%$, com diferença significativa $(P<0,05)$ entre o $T_{1}$ e $\circ T_{4}$. Este comportamento é concordante com TROUGHT \& DREW (1980) que trabalhando com plântulas de trigo observaram que o uso da água não mudou durante duas semanas de encharcamento mas a transpiração decresceu. Infere-se que, além do efeito das $\mathrm{PPAI}_{\mathrm{s}}$ ministradas até então no $T_{4}$, principalmente a hipoxia imposta nos dois dias de $\mathrm{TAH}$, resultaram numa menor, embora sem significância estatística, transpiração comparativamente com o $\mathrm{T}_{2}$ que esteve, durante todo o tempo com o $\mathrm{LF}$ a $15 \mathrm{~cm}$. O fato da intensidade transpirométrica do $\mathrm{T}_{4}$, embora significativa, ser apenas $10 \%$ menor que do $T_{1}$ pode indicar que a planta teve apenas um pequeno prejuízo pela hipoxia no processo de troca gasosa até então.

Espera-se que a resistência estomática da planta apresente-se inversamente proporcional à transpiração. Isso foi confirmado, apresentando uma tendência de crescimento inversamente com a intensidade de inundações, embora sem diferença significativa $(\mathrm{P}<0,05)$. $\mathrm{O}$ ajuste da abertura do estômato é um dos mais importantes mecanismos reguladores na planta. SOJKA et al. (1975) afirmam que o fechamento do estômato no trigo é também causado pela hipoxia das raízes. Esse fenômeno foi observado, a exemplo desse trabalho, indiretamente pela medida da resistência de 
difusão de folhas. $\mathrm{O}$ fenômeno de fechamento do estômato sob hipoxia nas raizes foi revisado por SOJKA \& STOLZY (1980). De acordo com eles não é possível explicar esse fenômeno assumindo como processo passivo causado pela queda do potencial de água na planta próprio do decréscimo da permeabilidade da raiz em condições anóxicas, como já foi discutido anteriormente neste trabalho. Sugerem a existência de, pelo menos, dois mecanismos envolvidos. O primeiro ligado à produção de elementos quimicamente ativos como o etileno. Isso é suportado pelo fato da produção de etileno aumentar durante o estresse, sendo acompanhado pela fechamento estomático; e outro na alteração do fluxo do íon de potássio para as células guardas com conseqüente mudança na sua turgescência. Essa hipótese é alicerçada num decréscimo do conteúdo de potássio na parte aérea quando as raízes estão sob hipoxia, exatamente como o observado e já discutido nesse trabalho.

Nova leitura dos parâmetros de transferência, executada aos 52 DAE, portanto com 5 dias de $\mathrm{TAH}$ no $\mathrm{T}_{4}$ e à 12 dias da segunda inundação (4hs) do $\mathrm{T}_{3}$, A temperatura da folha só elevou-se significativamente no $\mathrm{T}_{4}$ significando que, que após 5 dias de hipoxia permanente, a planta já manifestava alteração acentuada na temperatura foliar no $T_{4}$, enquanto o $T_{3}$ e o $T_{2}$ permaneciam, teoricamente, sem prejuízo metabólico. A umidade relativa, apresentou uma tendência decrescente com a hipoxia, destacando-se a significância do $T_{4}$ em relação ao $T_{1}$. Contrariando essas variações, a transpiração apresentou-se estatisticamente igual em todos os tratamentos, homogeneidade essa não correspondida pela resistência estomática cujo comportamento foi absolutamente coerente com a umidade relativa e com a tendência da temperatura, além de também 
ser coerente com a intensidade diferenciada de estresse. Particularmente em relação à resistência estomática, a não diferenciação do $T_{4}$ na primeira avaliação (aos 2 dias de TAH) e a significância na segunda (no $5^{\circ}$ dia de TAH) é o mesmo que o observado por HUANG et al. (1994) com duas cultivares de trigo, com distintas tolerância ao encharcamento. Apontam que a condutância estomática só decresceu significativamente à partir do $5^{\circ}$ dia de encharcamento.

Infere-se, por esses resultados que, após 5 dias sob estresse hídrico acentuado, há uma grande coerência dos parâmetros de transferência com o aspecto fenotípico da planta e com o grau de hipoxia. A indefinição no $T_{3}$ espelha sua condição intermediária de estresse onde os PPAIs mais brandos pode estar resultando vantagens em uns parâmetros e desvantagens em outros, função, em ultima análise, do confundimento metabólico que pode estar experimentando a planta.

Como observação final, os resultados apontam para uma maior sensibilidade do parâmetro resistividade estomática às condições de estresse hipóxico para a cultura do trigo que os outros parâmetros de transferência, inclusive a transpiração.

A hipoxia, além dos processos de transferências gasosas influi na bioquímica da planta, notadamente àquela relacionada ao sistema radicular. Alterações nas estruturas radiculares adaptadas podem modificar a performance dos processos anteriormente discutidos e as raízes, por sua vez, são modificadas pela ação do etileno.

Os resultados da amostragem do etileno nas raízes realizada aos 56 DAE são apresentados na Figura 10. 
Como o esperado, houve nítido e constante gradiente da taxa de emissão de etileno com o grau de hipoxia nas duas espécies. $\mathrm{O}_{4}$ apresentou-se, no T. aestivum, significativamente maior que o $\mathrm{T}_{1}$, enquanto no $T$. durum, esse mesmo tratamento foi significativamente maior que o $\mathrm{T}_{2}$ e o $\mathrm{T}_{1}$. Deve ser ressaltado também o coerente comportamento do $\mathrm{T}_{2}$ com tudo o que já foi acima discutido, manifestando também aqui uma posição intermediária e, nas duas espécies, de diferenças não significativas em relação ao $T_{1}$.

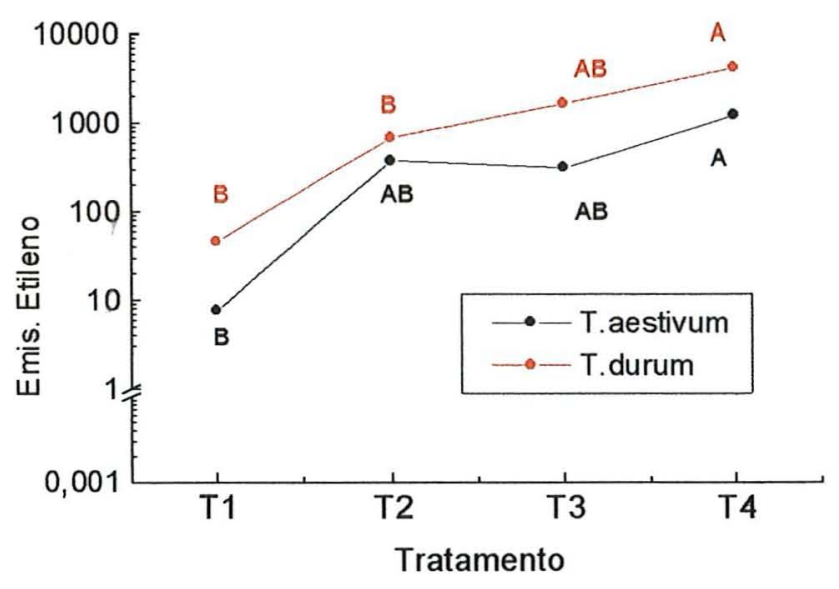

Figura 10. Avaliação do etileno $\left(\mathrm{nM} \mathrm{dia}{ }^{-1} \mathrm{~g}^{-1}\right)$ nas raizes do trigo, amostradas aos 56 DAE. Significância estatística $(P<0,05)$; Médias seguidas de mesma letra não diferem entre si, Duncan $5 \%$, Média $n=5$. Piracicaba, SP, ESALQ/USP.

A maior presença de etileno na planta é considerada um fator importante na adaptação da planta à hipoxia, uma vez que promove a formação de aerênquima. Especificamente em relação ao trigo sob encharcamento, HUANG et al. (1994), 
observaram a formação de aerênquima nas células corticais das raízes seminais e nodais, em maior extensão na cultivar tolerante, indicando diferença de comportamento entre as cultivares.

Os resultados da avaliação dos parâmetros físicos do LF realizada aos $69 \mathrm{DAE}$ são apresentados no Tabela 9.

A temperatura do solo ficou em torno de $22^{\circ} \mathrm{C}$, sendo que a diferença entre os tratamentos (amplitude de $1,6{ }^{\circ} \mathrm{C}$ aumentando do $\mathrm{T}_{2}$ para o $\mathrm{T}_{4}$ ) é considerada como ocasional, sem significância estatística.

Analisando-se o nível das temperaturas lidas no $\mathrm{T}_{3}$ e $T_{4}$, pode-se considerá-las altamente desfavoráveis à planta sob hipoxia em função da menor capacidade de saturação de $\mathrm{O}_{2}$ da água do solo. Além disso, o que é mais crítico, eleva a taxa de consumo de $\mathrm{O}_{2}$. Pode-se avaliar o que representa esse particular, comparando-se com o observado por CANNELL et al. (1980), também em trigo, sob temperaturas de solo muito mais amenas. Relatam que com temperatura de $4{ }^{\circ} \mathrm{C}$ a $20 \mathrm{~cm}$ de profundidade, o $\mathrm{O}_{2}$ do solo esgotou-se em 13 dias, em contrate com o esgotamento completando-se em apenas 5 dias quando a temperatura do solo foi aumentada para $11-12^{\circ} \mathrm{C}$.

Sob o aspecto nutricional, esse nível de temperatura torna-se também um fator desfavorável. Segundo LABANAUSKAS et al., (1975), todos os elementos - N, P, K, $\mathrm{Ca}, \mathrm{Mg}, \mathrm{Na}, \mathrm{Zn}, \mathrm{Mn}, \mathrm{Cu}$ e $\mathrm{Fe}$ - tiveram sua quantidade extraída pela planta e translocada para o grão diminuída quando a temperatura do solo passou de $15{ }^{\circ} \mathrm{C}$ para $25{ }^{\circ} \mathrm{C}$. 
$\mathrm{O} \mathrm{pH}$ a $20 \mathrm{~cm}$ de profundidade da superfície do solo foi praticamente igual nos tratamentos $T_{2}$ e $T_{3}$, enquanto o $T_{4}$ apresentou uma elevação (de aproximadamente $1,0)$, estatisticamente não significativa. Tendo-se em mente que, até essa profundidade, todos os três tratamentos foram submetidos às mesmas condições, a única base física de interpretação para essa tendência de maior $\mathrm{pH}$ do $\mathrm{T}_{4}$ é considerando-se o fenômeno normal de elevação do $\mathrm{pH}$ em solos ácidos com o encharcamento pelo consumo do $\mathrm{H}^{+}$ nas reações químicas decorrentes. Essa elevação, portanto, seria creditado, exclusivamente à camada de $15 \mathrm{~cm}$ superficiais que, alem de ter sido submetida ao encharcamento com maior freqüência e, consequentemente, com um mais intenso processo de redução, encontrava-se a 22 dias sob TAH contra 1 dia de TAH do $T_{3}$ e nenhum do $T_{2}$.

Geralmente, em solos ácidos, como é o caso deste, o pH primeiro declina por vários dias, em função da produção de $\mathrm{CO}_{2}$ por microorganismos, elevando-se posteriormente a um valor estável de 6,5 - 7,2 por várias semanas para, finalmente, recuperar o pH inicial (LARSON et al., citado por SCHAFFER et al., 1992).

Quanto ao oxigênio dissolvido na água, também não houve diferença estatística entre os tratamentos. (Tabela 9). A tendência de maior do $T_{2}$ deve-se ao fato, á principio, da presença do LF rebaixado a $15 \mathrm{~cm}$, permitindo alguma aeração do solo.

De modo geral, observa-se que a porcentagem de oxigênio dissolvido na água do estrato de saturação do solo apontava porcentagens muito baixas, o que retrata o alto grau de restrição à que estavam submetidas as plantas, apresentando-se nos três tratamentos, a menos que $1 \%$ da concentração de oxigênio do ar atmosférico. 
Tabela 9. Análise de parâmetros físicos do $L F$ no $22^{\circ}$ dia de T.A.H no $T_{4}$ e 1 dia no $T_{3}$. Piracicaba, SP, ESALQ/USP

\begin{tabular}{|c|c|c|c|c|c|c|}
\hline TRAT & $\begin{array}{c}\text { OXIG. } \\
\%\end{array}$ & $\begin{array}{l}\mathrm{T} . \\
{ }^{\circ} \mathrm{C}\end{array}$ & C. $\mathrm{O}_{2} \mathrm{~S}$. & C. $\mathrm{O}_{2}$ EXT. & $\mathrm{C} . \mathrm{O}_{2} \mathrm{~A}$ A. A. & $\mathrm{pH}$ \\
\hline $\mathrm{T}_{2}$ & $29,0(2,9)$ & 21,8 & 8,8 & 2,5 & 270 & $5,5(0,4)$ \\
\hline$T_{3}$ & $27,2 \quad(3,9)$ & 22,6 & 8,6 & 2,3 & 269 & $5,4(0,5)$ \\
\hline $\begin{array}{c}\mathrm{T}_{4} \\
\mathrm{~F}\end{array}$ & $\begin{array}{c}28,8(4,3) \\
0,6^{\text {ns }}\end{array}$ & 23,4 & 8,4 & 2,4 & 267 & $6,3(0,3)$ \\
\hline CV $(\%)$ & $\begin{array}{c}0,06 \\
29,5\end{array}$ & $\begin{array}{r}2,53 \\
4,9\end{array}$ & & 29,5 & & $\begin{array}{l}1,43 \\
16,4\end{array}$ \\
\hline
\end{tabular}

${ }^{(\mathrm{ns})}$ não significativo $(\mathrm{P}<0,05) ;(0,4)$ - Erro padrão, $\mathrm{n}=5$.

C. $\mathrm{O}_{2}$ S. - Conteúdo de Oxigênio dissolvido na água saturada com ar em função da temperatura.

C. $\mathrm{O}_{2}$ EXT. - Conteúdo do oxigênio dissolvido no extrato de saturação do solo (sem correção de pressão atmosférica e sais dissolvidos na água.

C. $\mathrm{O}_{2}$ A. A. - Concentração de oxigênio em ar atmosférico saturado com água na temperatura média da avaliação (GLINSKI \& STEPNIEWSKI, 1985).

Considerando-se que a concentração de $\mathrm{O}_{2}$ do solo aerado é próxima do ar atmosférico (LINDSTROM, citado por DREW, 1992), e correlacionando-se com o rendimento de grãos obtido nos dois tratamentos, descritos à seguir (Tabela 11), teríamos então uma quantificação do reflexo da hipoxia na produtividade do trigo para nossas condições (tropicais) e, além disso, sob ambiente natural. É óbvio, mas importante ressaltar que o decréscimo do rendimento de grãos não é, as vezes, proporcional com a diminuição da concentração de $\mathrm{O}_{2}$.

WEBB \& ARMSTRONG (1983), trabalhando com raizes de arroz intactas desenvolvendo-se em meio de agar anaeróbico mas com transferência interna de $\mathrm{O}_{2}$ observaram que o crescimento somente cessou quando a concentração de $\mathrm{O}_{2}$ se aproximou de zero. Também, obviamente, esta consideração deve ser interpretada com 
cuidado pois, independente das transformações/adaptações apresentadas neste trabalho pelo trigo, reconhecidamente, há enorme diferença quanto à eficiência adaptativa à hipoxia entre as duas culturas.

Aos 73 DAE o ciclo fenológico mais avançado do T. aestivum dentro do $T_{1}$ apontava para uma diferenciação natural genética. No entanto, entre tratamentos, no T. aestivum, houve um gradiente com o grau de encharcamento $(100,90,80$ e $50 \%$ de espigamento para $T_{1}, T_{2}, T_{3}$ e $T_{4}$, respectivamente), inferindo-se, ter havido um retardando no ciclo com a hipoxia. No $T$. durum, pelo fato da testemunha estar a 100 $\%$ de espigamento e todos os outros tratamentos numa porcentagem menor que $10 \%$, sugere que, à despeito de ser mais tardio que o $T$. aestivum, o efeito da hipoxia no ciclo foi ainda maior, sem muita distinção, no entanto, entre as intensidades com que elas foram implementadas.

Infere-se que, à despeito das possíveis adaptações fisiomorfológicas das plantas à hipoxia, à partir do emborrachamento, a inundação permanente passa a afetar muito. Além da maior atividade fisiológica específica nesse estádio, o efeito da hipoxia foi maximizado pelas atipicamente altas temperaturas ocorridas praticamente durante todo o ciclo. BEARD \& MARTIN (1970), trabalhando com uma também gramínea, Poa annua, $L$., encontraram que, sob $10{ }^{\circ} \mathrm{C}$ ocorreu $50 \%$ de morte com 70 dias de encharcamento. Já à temperatura de $20^{\circ} \mathrm{C}$ o mesmo percentual de mortes ocorreu logo aos 40 dias e, em torno de 10 dias, com a temperatura de $30^{\circ} \mathrm{C}$. 
Baseando-se nessa ultima informação, acrescida das anteriormente discutidas, de modo geral, pode-se inferir que o estímulo à adaptação não foi completamente eficiente em nenhum dos dois tratamentos $\left(\mathrm{T}_{3} \mathrm{e} \mathrm{T}_{4}\right)$.

Aos 75 DAE a análise da integridade do sistema radicular e das transformações morfológicas ocorridas na parte aérea, observou-se, na Figura 11B o aparecimento de raízes adventícias na planta do $T_{2}$.

Sob condição mais drástica de hipoxia (Figura 11C) a planta já apresenta a epiderme rompida, expondo cavidades com tecido poroso, que são, na realidade, tecidos facilitadores de penetração de $\mathrm{O}_{2}$ (KAWASE, 1981), além de raízes fortemente necrosadas.

A Figura 11D mostra, em detalhe, a emissão em profusão de raiz adventícias superficiais na planta do $T_{2}$, chamando a atenção para a base do colmo que permaneceu sadio e íntegro. Essa alta produção de raízes adventícias é coerente com os resultados obtidos na avaliação do etileno que, embora não estatisticamente significativo em relação ao $T_{1}$, nas duas espécies, sua curva apontam acentuado acréscimo no seu teor, notadamente no T. aestivum.

A Figura 12 mostra, comparativamente, a integridade do sistema radicular em função de cada manejo do LF. Observa-se nos tratamentos hipóxicos diferentes intensidades de necrose, mais acentuadas no $T_{3}$ e $T_{4}$. No $T_{2}$ ocorreu, quase que exclusivamente nos ápices das raizes mais velhas, enquanto nos outros envolvendo todo o sistema radicular. 
A diferença dos sintomas entre o $\mathrm{T}_{3}$ e o $\mathrm{T}_{4}$ pode ser por duas razões. Plantas do $\mathrm{T}_{3}$, menos adaptada, pela menor freqüência de PPAIs, teve maior comprometimento do sistema radicular após 7 dias de submersão. Já a maior freqüência de PPAIs no $T_{4}$ pode ter preparado melhor a planta para a drástica condição do TAH, encontrando a planta com maior numero de raízes adventícias, bem como com mais efetiva presença dos outros mecanismos adaptativos. Isso possibilitou que, mesmo após 28 dias de $\mathrm{TAH}$, as plantas apresentassem raízes vivas e à principio, efetivas.

As plantas do $T_{2}$, não tendo sido submetidas ao $T A H$, tiveram maior facilidade em manter suas raízes íntegras. Observa-se características típicas de raiz modificada pela hipoxia, ou seja, mais porosas, superficiais e com uma mucilagem notável envolvendo toda a raiz.

Todas as considerações acima são coerentes com os graus de comprometimento das condições físicas e químicas do solo (TDO e Potencial redox) do $T_{2}$ para o $T_{3}$ e $T_{4}$, diagnosticados e discutido anteriormente.

Por outro lado, sob condições hipóxicas, seqüencialmente, ocorre a morte das raízes primárias ou não adaptadas e um esforço metabólico da planta para a emissão de novas e mais adaptadas raízes. Como a amostragem foi realizada aos 28 dias de TAH no $T_{4}$ e 7 dias de $T A H$ no $T_{3}$, a primeira já podia ter passado pelo momento crítico de readaptação radicular. 

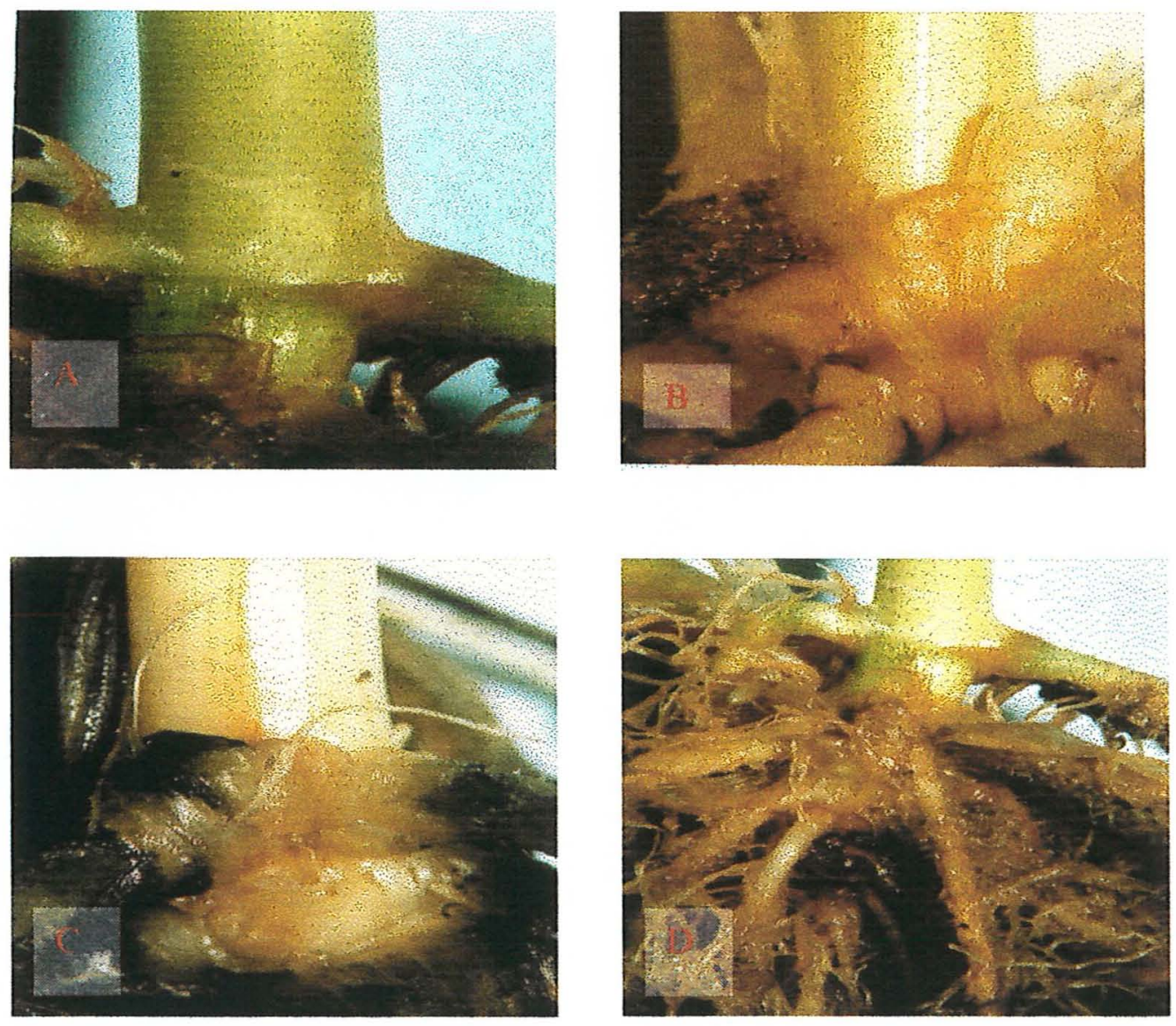

Figura 11. Transformações morfológicas no colo do trigo em função do manejo do LF. (A) $-\mathrm{T}_{1}$; (B) $-\mathrm{T}_{2}$; (C) $-\mathrm{T}_{4}$; (D) detalhe da proliferação de raízes adventícias no $\mathrm{T}_{2}$. Observação aos 75 DAE. Piracicaba, SP, ESALQ/USP. 

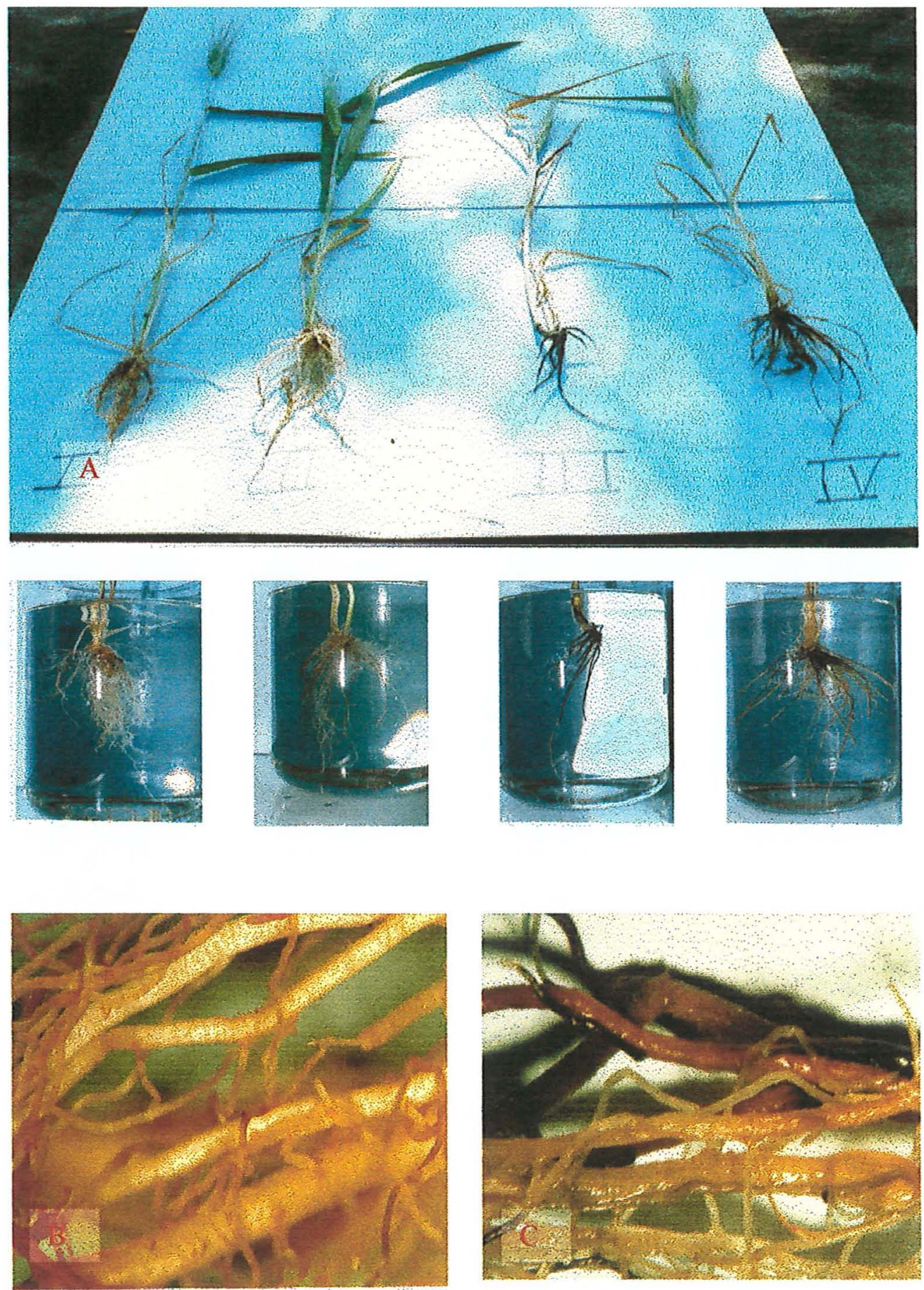

Figura 12. (A) Efeito dos diferentes manejos do LF na integridade do sistema radicular do Triticum aestivum, aos $75 \mathrm{DAE}$; (B) detalhe das raízes adventícias integras do $T_{2}$ e raízes adventícias íntegras e $(C)$ raízes primárias necrosadas. Piracicaba, SP, ESALQ/USP. 
Analisando-se o primeiro internó das plantas, verificou-se marcantes estrias verticais no colmo das plantas do T3 e T4, no T aestivum. Figura 13. Isso é sintoma típico de deficiência nutricional.
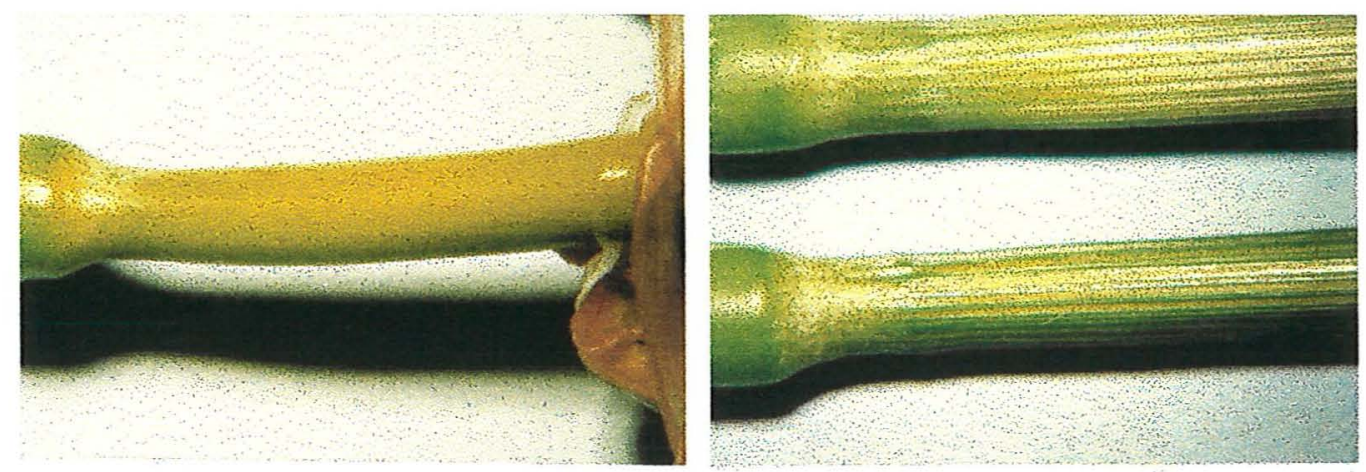

Figura 13. Efeito do encharcamento no primeiro entrenó do colmo do T. aestivum; $\mathrm{T}_{1}-$ a esquerda, $\mathrm{T}_{3}-$ a direita. Piracicaba, SP, ESALQ/USP. 
Na quantificação dos teores de nutrientes disponíveis à planta no LF executada aos $89 \mathrm{DAE}$, ou seja, aos 21 dias no $\mathrm{T}_{3}$ e 47 dias no $\mathrm{T}_{4}$ de $\mathrm{TAH}$, os teores encontrados foram comparados, em parte, com os valores máximos permitidos para consumo humano e, em parte, com os teores médios utilizados em solução hidropônica.

Observa-se, na Tabela 10, que, com exceção do cloreto e do sódio, nenhum elemento excedeu os limites máximos recomendados, em qualquer dos dois parâmetros de comparação. 
Por outro lado, a água do LF mostrou-se deficiente em todos os elementos básicos constituintes de uma solução hidropônica, auxiliando a interpretação das manifestações físicas acima descritas.

Obviamente, a disponibilidade total do nutriente em um solo encharcado deve ser avaliada através da associação dos elementos presentes no LF com aqueles constituintes da matriz do solo.

Porém, em termos práticos, considerando-se que as análises químicas do solo, anteriormente apresentadas e discutidas, também indicavam níveis deficientes de, praticamente todos os nutrientes, conclui-se que a nutrição da planta, via sistema radicular, seguramente foi prejudicada, tanto no comprometimento das raízes em função da carência do $\mathrm{O}_{2}$, como na pobre disponibilidade de nutrientes no extrato de saturação do solo.

Não tem-se explicação para a notável variação de sulfato entre os tratamentos não pode ser interpretada sob uma análise racional.

A elevação do $\mathrm{pH}$, comparado com o apontado pela análise original do solo, pode ser interpretada como benéfica.

WATERS et al., (1991) apontam que a tolerância do trigo, definida em seu trabalho como a habilidade de raízes seminais de alongar quando retornam ao ar, foi maior sob pH de 5,0 e 6,0 que a 4,0. 
Tabela 10. Análise da água coletada aos $89 \mathrm{DAE}$, aos 21 dias no $\mathrm{T}_{3}$ e 47 dias no $\mathrm{T}_{4}$ de TAH. Piracicaba, SP, ESALQ/USP.

\begin{tabular}{|c|c|c|c|c|}
\hline \multirow[t]{2}{*}{ Parâmetro } & \multicolumn{3}{|c|}{$\begin{array}{l}\text { Valor } \\
\left(\mathrm{mg} \mathrm{l}^{-1}\right)\end{array}$} & \multirow[t]{2}{*}{$\begin{array}{l}\text { VMPC } \\
\left(\mathrm{mg} \mathrm{l}^{-1}\right)\end{array}$} \\
\hline & $\mathrm{T}_{2}$ & $\mathrm{~T}_{3}$ & $\mathrm{~T}_{4}$ & \\
\hline nitrogênio & $\mathrm{nc}$ & nc & $\mathrm{nc}$ & \\
\hline sulfato & 25,3 & 2,50 & 52,3 & $67,0^{*}$ \\
\hline nitrato & $\mathrm{nc}$ & nc & 0,2 & 10,0 \\
\hline cloreto & 2,5 & 2,5 & 3,0 & $0,7^{*}$ \\
\hline fósforo & 0,01 & 0,01 & 0,01 & $31,0^{*}$ \\
\hline potássio & 2,7 & 2,7 & 2,3 & $234,0^{*}$ \\
\hline cálcio & 13,9 & 13,0 & 13,0 & $200,0^{*}$ \\
\hline magnésio & 7,0 & 7,1 & 7,5 & $48,0^{*}$ \\
\hline ferro & 0,1 & 0,1 & 0,1 & $5,0^{*}$ \\
\hline cobre & $\mathrm{nc}$ & $\mathrm{nc}$ & $\mathrm{nc}$ & $0,02^{*}$ \\
\hline manganês & $\mathrm{nc}$ & nc & $\mathrm{nc}$ & $0,5^{*}$ \\
\hline zinco & $\mathrm{nc}$ & $\mathrm{nc}$ & $\mathrm{nc}$ & $0,05^{*}$ \\
\hline sódio & 3,0 & 3,0 & 3,0 & 0,7 \\
\hline gás carbônico & 0,5 & 0,5 & 0,5 & 8,7 \\
\hline acidez & 7,9 & 7,9 & 8,4 & 18,9 \\
\hline dureza & 63,5 & 61,8 & 63,3 & 500,0 \\
\hline alcalinidade & 6,6 & 6,8 & 6,6 & \\
\hline $\mathrm{pH}$ & 7,3 & 7,4 & 7,3 & $6,5-8,5$ \\
\hline
\end{tabular}

Observação : VMPC - Valor máximo permitido (água para abastecimento consumo humano); * teores médios de solução hidropônica. 
Os resultados da avaliação dos parâmetros biométricos do trigo, incluindo o rendimento de grãos são apresentados na Tabela 11.

Analisando-se as datas de colheita, observa-se, tanto no T. aestivum como no T. durum, uma aceleração no ciclo com o estresse hipóxico, contrariando a tendência que vinha sendo observada ao longo do ciclo. (Figura 14A).

Pode-se inferir que se durante o desenvolvimento vegetativo a hipoxia teve efeito retardando o ciclo nos tratamentos hipóxicos, a partir do florescimento parece ter forçado a planta a acelerar a maturação, reduzindo o ciclo.

Isso é devido a conjugação de fatores, tais como, alta atividade metabólica, ápice da demanda transpirométrica e reduzido e comprometido sistema radicular.

Went et al. (1988), trabalhando com tres genótipos de trigo submetidos ao encharcamento de 10, 20 e 30 dias não observaram modificação no ciclo. O estádio fenológico (vegetativo) e a duração da hipoxia podem ser os responsáveis pela diferença. 
Nesse aspecto, notou-se uma ligeira heterogeneidade apresentando-se, lado a lado, plantas continuando o desenvolvimento e outras paralisando o ciclo (Figura 14B). Isso é explicado geneticamente uma vez que esses materiais, durante todo seu processo de melhoramento foram selecionados numa e para a condição de normoxia (solo aerado), fazendo com que, sob a condição experimental houvesse a manifestação de toda sua heterogeneidade genética à hipoxia.

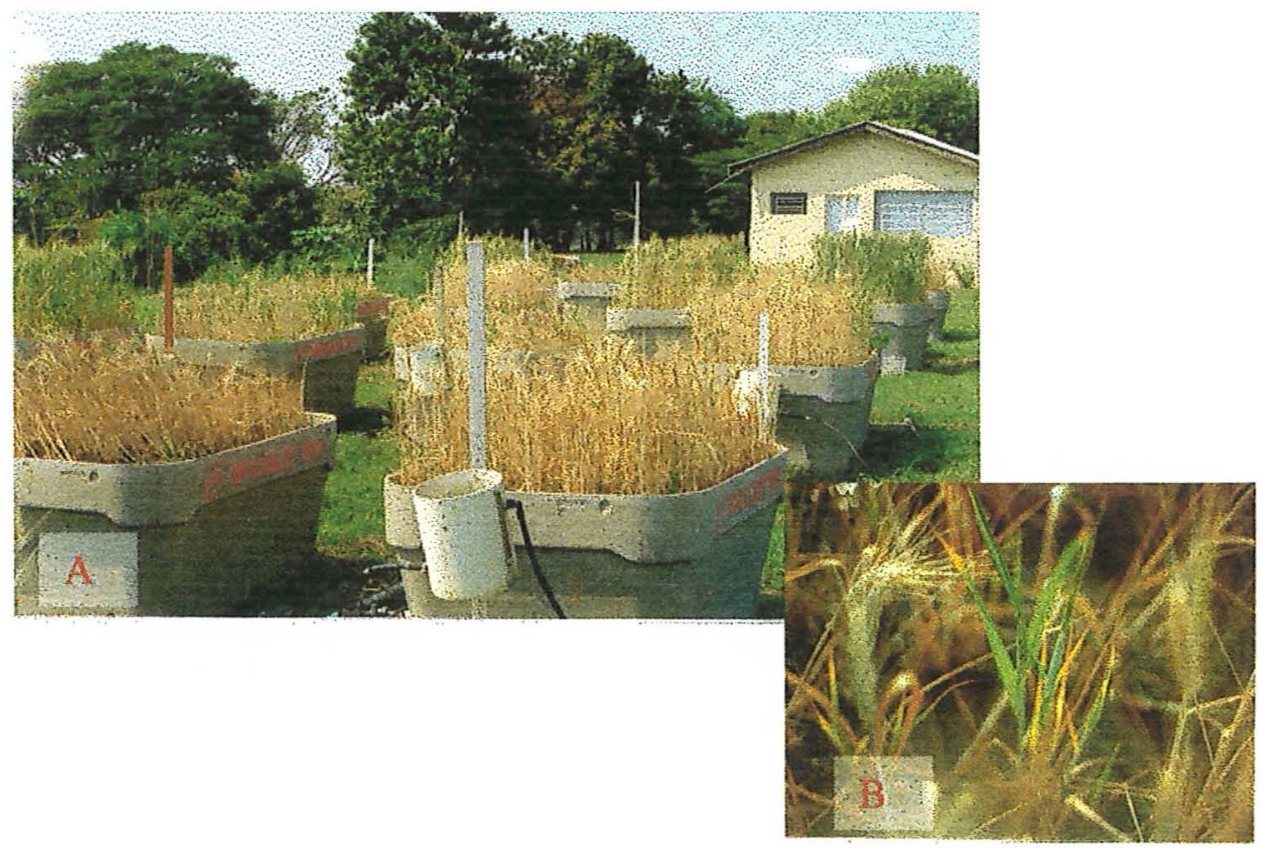

Figura 14. (A) Aspecto geral do experimento pouco antes da colheita; (B) heterogeneidade do material sob hipoxia. Piracicaba, SP, ESALQ/USP. 
Segundo GLINSKI \& STEPNIEWSKI, (1986), a tolerância das plantas ao encharcamento é função de vários fatores, dentre eles, do estádio de desenvolvimento da cultura em que ele foi implantado. No caso de cereais, como o trigo, o florescimento é um dos estádios mais sensíveis.

As considerações acima servem para explicar as mesmas datas de fechamento de ciclo dos tratamentos $\mathrm{T}_{3}$ e $\mathrm{T}_{4}$ e entre as duas espécies.

Já no $T_{2}$ talvez em função de uma condição mais amena, a forte influência da característica genética ainda prevaleceu (Tabela 11 e Figura 15).

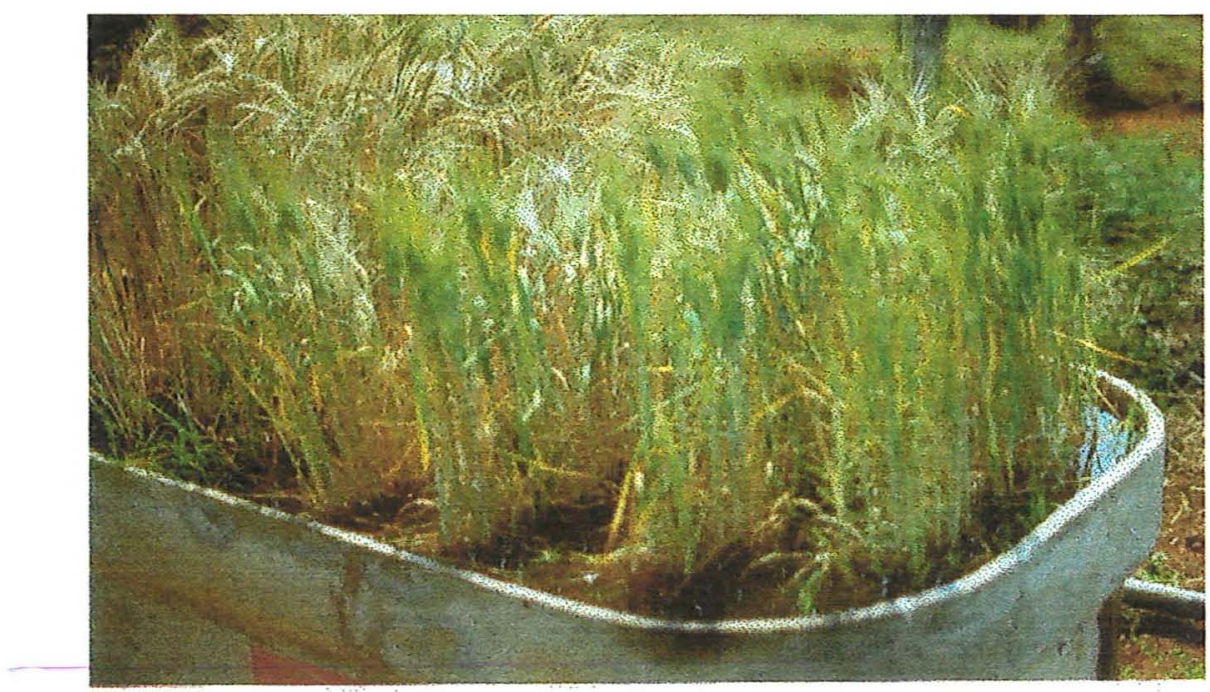

Figura 15. Diferenciação fenológica das duas espécies, T. Aestivum (a esquerda) e $T$. durum (a direita), sob encharcamento no $\mathrm{T}_{2}$. Piracicaba, SP, ESALQ/USP.

Como comentário geral, para as duas espécies, o rendimento de grãos apresentou um gradiente negativo com a intensidade de hipoxia. A produtividade do $T_{2}$, nas duas espécies, pouco menos da metade do $T_{1}$, mostra que, por um lado, foi 
significativo o prejuízo metabólico causado pela presença constante do $L F$ a $15 \mathrm{~cm}$, e, por outro, situando-se ao nível de $30 \%$ acima da média nacional, referenda um potencial para esse tipo de estudo.

No T. aestivum os parâmetros biométricos apresentaram-se com características típicas de plantas de desenvolvimento suprimido. De modo geral houve um gradiente dos parâmetros biométricos com o grau de hipoxia. A tendência de acréscimo da altura de plantas do $T_{3}$ em relação ao $T_{2}$, sem significância estatística, conjugada com um comportamento inversamente proporcional na massa da matéria seca (significativo $\mathrm{P}<$ $0,05)$ indica uma tendência ao estiolamento no $T_{3}$ em relação do $T_{2}$.

Já no $\mathrm{T}_{4}$, tanto a altura como a MMS atingiram o menor valor traduzindo uma nítida limitação no desenvolvimento. Apesar de não ter havido vantagem estatística do $T_{2}$ em relação ao $T_{3}$ nos demais componentes de produção, a MMS foi determinante para o rendimento de grãos, ser significativamente distinto $(\mathrm{P}<0,05)$. Pode-se inferir que tanto a TAH como o momento em que ela foi aplicada no $T_{3}$ foi a causa do comprometimento da MMS em relação ao $\mathrm{T}_{2}$, bem como assim atestam o numero de grão por espigueta, grão por espiga e massa de mil sementes, parâmetros esses fortemente influenciados pela performance da planta no florescimento/formação de grão.

De modo geral, os resultados biométricos apontam uma coincidência com o obtido por WENT et al. (1988), com trigo submetido ao encharcamento de 10,20 e 30 dias. Apontam que houve decréscimo no peso de grãos, comprimento da espiga, altura, e peso fresco da planta. 
Os rendimento de grãos dos $T_{3}$ e $T_{4}$ estatisticamente menores que o $T_{2}$ permitem fazer-se algumas conjecturas.

A primeira é que, sem duvida, os três manejos induziram adaptações fisiomorfológicas tais que permitiram a sobrevivência das plantas mesmo sob encharcamento completo por mais de 50 dias, como no caso do $\mathrm{T}_{4}$. $\grave{A}$ título de comparação, BEARD \& MARTIN (1970), afirmam que a Agrostis palustris Huds., a mais tolerante forrageira de três testadas, após 60 dias de continua submersão resultou apenas $49 \%$ de sobrevivência sob água à temperatura de $20{ }^{\circ} \mathrm{C}$ - semelhante a deste experimento.

A segunda é que, se estimuladas à adaptação pelas PPAIS, não o foram na intensidade ou eficiência que resultassem parâmetros biométricos de produção e nível de rendimento de grãos aceitáveis. Concorreram negativamente, é inegável, as atípicas altas temperaturas no período, bem como um reconhecido período talvez excessivamente longo de encharcamento contínuo no TAH, dificilmente observado na prática em uma várzea, dado ao normal refluxo hidrológico com o cessar do período chuvoso (recarga). Segundo CRAWFORD \& BRAENDLLE (1996), prolongada anoxia sob altas temperaturas esgotam a reserva de carbohidratos e permite o acúmulo de metabólitos causando danos ao tecido celular quando reoxigenados.

Não pode ser negligenciado, por outro lado, o adicional efeito negativo da condição de água estagnada, executada nesse experimento, facilmente evitado em condições naturais de várzeas. Segundo DAVIS \& MARTIN, citados por BEARD \& MARTIN (1970), forrageiras submetidas a encharcamento morrem mais rapidamente 
sob condição de água estagnada que sob água corrente.

Já a comparação relativa entre o $T_{3}$ e $T_{4}$ leva a crer que a maior freqüência de $\mathrm{PPAI}_{\mathrm{S}}$ do $\mathrm{T}_{4}$ foi absolutamente prejudicial, baseando-se no fato de ter havido redução em todos os parâmetros biométricos, servindo para reforçar a tese da não transmissividade dos efeitos benéficos de um estímulo temporário para um outro subsequente. O perfeito entendimento desse processo pode ser a chave do sucesso na eleição de um manejo do L.F. mais adequado.

Um outro ponto pode estar ligado à bioquímica da planta. Concomitantemente com a maior freqüência de estresse hipóxico, ocorre também uma mais freqüente reoxigenação do solo que pode vir a ser tão ou mais deletéria que a própria hipoxia em si (CRAWFORD \& BRAENDLLE, 1996).

Pesquisas recentes apontam danos irreversíveis no tecido vegetal quando retornam ao ar, havendo a formação de radicais ativos e produtos oxidativos tóxicos como o acetaldeído (CRAWFORD \& BRAENDLLE, 1996). Essa descoberta bioquímica atende antigas controvérsias tais como o efeito tóxico do etanol agora podem ser explicados. Acumulados em plantas sob anoxia, esse produto final da via fermentativa da glicólise assiste à oxidação do ferro reduzido (anteriormente discutida a elevação do seu teor sob hipoxia, apresentado pela análise foliar) e formação de oxigênios ativos, como o superóxido $-\mathrm{Fe}^{2+}+\mathrm{O}_{2} \Rightarrow \mathrm{Fe}^{3+}+\mathrm{O}^{2-}$; seguindo-se a formação de peróxido de hidrogênio através da ação do superóxido dismutase (SOD) $2 \mathrm{O}^{2-}+2 \mathrm{H}^{+}+\mathrm{SOD} \Rightarrow \mathrm{H}_{2} \mathrm{O}_{2}$; finalmente, o etanol acumulado reage com esse produto originando o acetaldeído, $-\mathrm{C}_{2} \mathrm{H}_{5} \mathrm{OH}+\mathrm{H}_{2} \mathrm{O}_{2}+$ catalase $\Rightarrow \mathrm{CH}_{3} \mathrm{CHO}+2 \mathrm{H}_{2} \mathrm{O}$, esse 
sim, tóxico e que promove danos ao tecido vegetal

Esses conceitos, associados com o fato de que, em algumas plantas (ex. soja), períodos curtos de anoxia resultam na produção de radicais superóxidos enquanto em longos há a indução de altos níveis de atividade do superóxido dismutase que, por sua vez promovem a proteção das plantas quando estas retornam para o ar (TOAI \& BOLLES, 1991), fazem com que a utilização de manejos do LF que evitem a elevação e a retirada brusca da água no horizonte que sustenta o sistema radicular ( ao contrário do implementado nesse trabalho), sejam, á principio, mais indicados.

Quanto ao T. durum, o gradiente dos parâmetros biométricos com o grau de hipoxia fica ainda mais evidente. Permitindo apenas uma consideração, infere-se que a tendência do comprimento da espiga e do numero de espigueta maior no $T_{4}$ em relação ao $T_{3}$ (não significativo $P<0,05$ ), sugere alguma possível tendência adaptativa. Essa vantagem, no entanto, perdeu sua importância com o decréscimo acentuado nos parâmetros biométricos desenvolvidos no período reprodutivo, quando da aplicação do TAH. À rigor, nenhuma outra consideração ou hipótese merece ser confecturada diante da clara resposta do T. durum à hipoxia.

$\mathrm{Na}$ comparação entre as duas espécies, parece haaver para uma ligeira vantagem de performance do T. aestivum sob hipoxia, manifestada nos $T_{2}$ e $T_{3}$. Como essa vantagem também é manifestada no $T_{1}$, a influência de uma adaptabilidade diferenciada à hipoxia fica temerária, podendo ser uma manifestação de caráter puramente genético. 
Tabela 11. Parâmetros biométricos do T. aestivum e do T durum. Piracicaba, SP, ESALQ/USP.

\begin{tabular}{|c|c|c|c|c|c|c|c|c|c|}
\hline TRAT & $\begin{array}{l}\mathrm{MMT} \\
\mathrm{Kg} \cdot \mathrm{m}^{-1}\end{array}$ & $\begin{array}{c}\text { MMS } \\
\mathrm{g}\end{array}$ & $\begin{array}{l}\text { ALT } \\
\mathrm{cm}\end{array}$ & $\begin{array}{l}\mathrm{CE} \\
\mathrm{cm}\end{array}$ & NE & NGE & NGT & $\begin{array}{c}\text { DC } \\
\text { DAE }\end{array}$ & $\begin{array}{l}\text { REND } \\
\text { Kg.Ha }{ }^{-1}\end{array}$ \\
\hline \multicolumn{10}{|c|}{ T. aestivum. } \\
\hline TRAT I & $0,45 \mathrm{~A}^{(1)}$ & $29,90 \mathrm{~A}$ & $74,54 \mathrm{~A}$ & $7,19 \mathrm{~A}$ & $17,09 \mathrm{~A}$ & $46,75 \mathrm{~A}$ & $2,74 \mathrm{~A}$ & 122 & $4.659,2 \mathrm{~A}$ \\
\hline TRAT 2 & $0,38 \mathrm{AB}$ & 19,92 B & $50,00 \mathrm{~B}$ & $6,76 \mathrm{~A}$ & $16,03 \mathrm{AB}$ & $34,10 \mathrm{~B}$ & $2,13 \mathrm{~B}$ & 119 & $2.170,2 \mathrm{~B}$ \\
\hline TRAT 3 & $0,34 \mathrm{~B}$ & $12,98 \mathrm{C}$ & $52,62 \mathrm{~B}$ & $7,15 \mathrm{~A}$ & $16,41 \mathrm{AB}$ & $32,20 \mathrm{~B}$ & $1,96 \mathrm{~B}$ & 115 & 947,30 \\
\hline TRAT 4 & $0,32 \mathrm{~B}$ & $12,51 \mathrm{C}$ & $49,73 \mathrm{~B}$ & $6,48 \mathrm{~A}$ & $14,60 \mathrm{~B}$ & $21,60 \mathrm{C}$ & $1,48 \mathrm{C}$ & 115 & 437,60 \\
\hline $\mathrm{F}$ & 7,2 & 103,0 & 25,9 & 1,7 & 3,3 & 20,3 & 21,4 & & 98,2 \\
\hline C.V.(\%) & 13,1 & 9,7 & 9,3 & 8,5 & 8,1 & 15,2 & 12,0 & & 20,1 \\
\hline \multicolumn{10}{|l|}{ T. durum. } \\
\hline TRAT 1 & $0,32 \mathrm{AB}$ & $23,07 \mathrm{~A}$ & $63,20 \mathrm{~A}$ & $5,91 \mathrm{~A}$ & $15,78 \mathrm{~A}$ & $49,96 \mathrm{~A}$ & 3,17 & 125 & $3.838,6 \mathrm{~A}$ \\
\hline TRAT 2 & $0,36 \mathrm{~A}$ & $18,26 \mathrm{~B}$ & $58,60 \mathrm{~A}$ & $6,07 \mathrm{~A}$ & $15,06 \mathrm{~A}$ & $33,72 \mathrm{~B}$ & 2,24 & 122 & $1.821,8 \mathrm{~B}$ \\
\hline TRAT 3 & $0,39 \mathrm{~A}$ & $11,22 \mathrm{C}$ & $44,00 \mathrm{~B}$ & $5,47 \mathrm{~A}$ & $14,31 \mathrm{~A}$ & $22,89 \mathrm{C}$ & 1,60 & 115 & $606,9 \mathrm{C}$ \\
\hline TRAT 4 & $0,27 \mathrm{~B}$ & $11,35 \mathrm{C}$ & $35,43 \mathrm{~B}$ & $6,04 \mathrm{~A}$ & $15,01 \mathrm{~A}$ & $17,02 \mathrm{C}$ & 1,13 & 115 & $449,9 \mathrm{C}$ \\
\hline$F$ & $6,6^{*}$ & $117,0^{*}$ & $36,0^{*}$ & $1,6^{\mathrm{ns}}$ & $1,6^{\mathrm{ns}}$ & $67,6^{*}$ & & & $142,0^{*}$ \\
\hline C.V. $(\%)$ & 14,0 & 7,3 & 9,5 & 8,2 & 6,9 & 12,7 & & & 17,5 \\
\hline
\end{tabular}

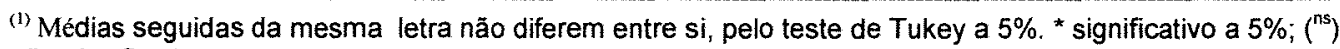
näo significativo.

MMT - Massa da matéria seca.

REND - Rendimento de grãos

MMS - Massa de mil sementes

ALT - Altura da planta

$\mathrm{CE}$ - Comprimento da espiga
NE - Numero de Espigueta

NGE - Numero de grão por espiga

NGT - Numero de grão por espigueta DC - Data de colheita 


\section{4 - CONCLUSÕES}

Os resultados apontam que:

- O potencial de água na folha foi afetado pela completa submergência da parte subterrânea, já em sua menor duração, não havendo, porém, correspondência com a manifestação fenotípica da cultura;

- A resposta diferenciada de exigência nutricional e/ou capacidade extração entre as duas espécies sob hipoxia indica que o sucesso produtivo do trigo sob hipoxia pode vir a ser condicionado a estudos específicos sobre suas exigências específicas e, consequentemente, a um plano de fertilização mais ajustado;

- A adubação foliar não contribuiu para suprir as deficiências nutricionais da planta decorrentes da limitação na absorção via sistema radicular, causada pela hipoxia no solo ou, se o fez, foi de forma insuficiente, sugerindo-se estudos específicos;

- A resistividade estomática mostrou-se o parâmetro de maior sensibilidade na planta de trigo sob encharcamento;

- Os manejos empregando curtos períodos de hipoxia induziram adaptações fisio-morfológicas tais que permitiram a sobrevivência das plantas mesmo sob encharcamento contínuo por mais de 50 dias. Essas, porém, não o foram na intensidade ou eficiência que resultassem parâmetros de produção 
num nível adequado;

- O manejo do lençol freático mantido a $15 \mathrm{~cm}$ de profundidade durante todo o ciclo fenológico foi o que propiciou melhor performance do trigo;

- A submergência intermitente mostrou-se altamente prejudicial, com o efeito intensificando-se com o aumento da freqüência da submersão, não sustentando a tese da transmissividade ou acúmulo de induções adaptativas. 


\title{
5 - EFEITO DE TRES DIFERENTES MANEJOS DO LENÇOL FREÁTICO NA ADAPTAÇÃO FISIOMORFOLÓGICA DO FEIJOEIRO (PHASEOLUS VULGARIS, L. $)$ AO ENCHARCAMENTO.
}

\author{
Autor: Rinaldo de Oliveira Calheiros \\ Orientador: Prof. Décio Eugênio Cruciani
}

\section{RESUMO}

Estudou-se o efeito de três manejos do lençol freático na indução de adaptações fisiomorfológicas da cultivar Bat 477 de feijão (Phaseolus vulgaris, l.) à hipoxia, caracterizando e inferindo a influência relativa dos principais fatores físicos, químicos e biológicos interferentes. O experimento foi conduzido na ESALQ/USP, Piracicaba, SP, simulando-se o máximo um meio físico/condição natural de uma várzea. Após a indução no período vegetativo, a eficiência dos manejos foi forçada à manifestar-se através de inundação temporária no fim do florescimento/formação de vagens. - Os parâmetros biométricos de crescimento, embora acusando prejuízo da hipoxia, evidenciaram a utilização pela planta de mecanismos adaptativos morfológicos (raízes adventícias e lenticelas), biológicos (fixação de N) e fisiomorfológicos (resistividade estomática e transpiração); os parâmetros biométricos de produção mostraram que os manejos com o lençol freático mantido a $15 \mathrm{~cm}$ e com sua elevação gradual foram efetivos, permitindo à planta completar seu ciclo, além de resultar menor comprometimento da qualidade de grãos; em plantas submetidas à hipoxia, o estudo da nodulação só será completo se respeitar a dinâmica de emissão de raízes adventícias, 
dado a gradativa substituição de raízes normais pelas adventícias; a alternância de vantagens relativas nos parâmetros biométricos de colheita entre os manejos de lençol estabilizado a $15 \mathrm{~cm}$ e com elevação gradativa resultando na não diferença estatística no rendimento de grãos, leva-se à recomendação do uso de cultivares de ciclo mais longo nesse tipo de estudo.

Termos de indexação: Drenagem, várzea, hipoxia, mesófitas, adaptação. 


\section{EFFECT OF THREE DIFFERENT WATER TABLES MANAGEMENT ON THE PHYSICAL-MORPHOLOGICAL ADAPTATION TO FLOODING TOLERANCE OF SNAP BEANS (PHASEOLUS VULGARIS, L)}

\section{SUMMARY}

The effect of three different water table management in the physicalmorphological adaptation to flooding tolerance of snap beans (Phaseolus vulgaris, L. ), cv. BAT 477 were studied and discussed the relative influence of the mains physicals and biological factors interfering. After induction at vegetative growth stage, the efficiency of management was enforced to show by a short-term waterlogging event at reproductive stage. The biometric parameters of growth, although showing damage caused by hipoxia, showed the utilization by the plant of adaptive mechanisms, such as morphological (adventitious roots and lenticels), biological ( $\mathrm{N}$ fixation) and physicalmorphological (diffusion resistance and transpiration). On the other hand, the yield biometric parameters showed that the water table maintained at $15 \mathrm{~cm}$, as well as its gradual elevation, were effective in inducing adaptive mechanisms that allowed the plant finish its phenological cycle, besides to result minor damage on quality of the grain. In spite of that, there was not significant difference in the yield comparing to the absence inductive management. Nodulation studies only will be complete if in concordance with the adventitious root emission dynamics. The alternate biometric advantages between the two managements, resulted in no statistically significant differences in the yield, suggesting to be of advantage the use of longer cycle cultivars when in hipoxic conditions.

Key-words: drainage, low land, mesophycs plant, adaptation, waterlogging. 


\section{1 - INTRODUÇÃO}

A importância da incorporação das várzeas, tecnicamente denominadas terras baixas, ao sistema produtivo, tem sido bastante incentivado. Seu aproveitamento, no entanto, deve estar submisso, à premissa básica da conservação ambiental, atendendo-se ao binômio: sistemas (sucessão de culturas) rentáveis e de concepção conservacionista.

A implantação de sistemas de suscessão de cultuara e ou rotação exige a utilização de culturas mesófitas, que se torna um problema sendo reconhecido que em terras baixas a monocultura é problema mundial (GARRITY \& PERNITO, 1996).

Nesse contexto o feijão seria a cultura ideal, em parceria com o arroz. De boa rentabilidade econômica, presta-se muito bem a pequenas e médias áreas.

Como solução do impasse entre a produção e a degradação, surgem os trabalhos de tolerância fisio-morfológica das culturas ao encharcamento (hipoxia/anoxia).

Este campo de estudo, no entanto, apresenta-se com considerável grau de dificuldade pois seu sucesso é dependente de uma série de fatores produtivos cuja ação individual, bem como sua interatividade, tendem à condicionar o sucesso desse tipo de 
exploração agrícola à uma difícil interpretação holística dos resultados. Assim, a dificuldade inicial é a sistematização dos fatores interferentes.

Tem sido observado que os resultados são muito variáveis, em função da cultura, cultivar, clima (com reflexos nos processos de trocas gasosas, principalmente a resistência estomática e a transpiração), solo (tipos e velocidades das reações químicas) e manejo da água ao longo do ciclo fenológico. Dentre as culturas e dentre as leguminosas, o feijoeiro é das mais suscetíveis (HODGSON et al., 1989), sendo escasso seu estudo sob hipoxia/anoxia e, portanto, sua resposta é pouco conhecida ( SINGH et al., 1991).

O desconhecimento torna-se ainda maior se considerado a combinação dos seguintes fatores: para as nossas condições, sob condição natural, durante todo o ciclo, com os principais fatores interferentes monitorados. A influência do clima é tão grande que os trabalhos, em sua maioria realizados em regiões de clima temperado, devem ser interpretados com muito cuidado. No nosso clima a temperatura maximiza a hipoxia tanto pela menor dissolução do $\mathrm{O}_{2}$ na água como pelo maior consumo da planta $\mathrm{e}$ microorganismos implicando no aumento da velocidade das reações químicas.

Nesse estudo, o monitoramento da taxa de difusão do oxigênio (TDO) e a concentração de $\mathrm{O}_{2}$ no solo é muito importante e tem sido correlacionadas com várias respostas da planta (SOJKA \& SOLTZY, 1980). Quanto a esse último, STOLZY \& LETEY, 1964 apontam que a resposta da parte aérea com a variação da TDO distribuise numa larga faixa, dependente da espécie e do estádio de desenvolvimento. Para plantas no estádio vegetativo, a TDO crítica é em torno de $40.10^{-8} \mathrm{mg} \mathrm{cm}^{-2} \mathrm{~min}^{-1}$ e que, no entanto, para o florescimento e frutificação a TDO ótima é mais elevada. 
Como efeitos decorrentes da baixa concentração de $\mathrm{O}_{2}$, surgem complicadores de natureza física como a penetração das raízes e permeabilidade do solo; nutricionais tanto pela menor disponibilidade de nutrientes às raízes como resultado de diluição e lixiviação de nutrientes, como pelo comprometimento da eficiência de absorção do sistema radicular; químicas, como potencial redox - parâmetro quantitativo eletroquímico (PONNAMPERUMA, 1984), e pH; e biológicas, como proliferação de algas e organismos anaeróbicos.

Quanto à debilidade nutricional da planta, parece ser possivel minimizar os efeitos da hipoxia se contornado esse problema. HUANG et al. (1994), trabalhando com duas cultivares de trigo de inverno, durante 17 dias sob encharcamento e com duas concentrações de nutrientes da solução de Hoagland, observaram que com a concentração dobrada, houve redução da taxa de declínio da fotossíntese, conteúdo de clorofila, e aumento do nível de nitrogênio na parte aérea e a taxa de crescimento, especialmente na cultivar mais suscetível.

As reações químicas e vários produtos de excreção de bactérias alteram o potencial de oxi-redução do solo, parâmetro quantitativo eletroquímico (PONNAMPERUMA, 1984), cuja taxa de redução é dependente do $\mathrm{pH}$, temperatura, conteúdo de matéria orgânica e do tipo de doadores de elétrons. É considerado um indicador utilíssimo do potencial de sobrevivência de uma cultura em um dado tipo de solo.

Teoricamente, pode ser factivel induzir-se a adaptabilidade fisiomorfológica das plantas através de um regime de hipoxia/anoxia específico, exercido pelo lençol freático (L. F.) ao longo do desenvolvimento vegetativo. 
O estabelecimento abrupto do estado hipóxico abaixa significativamente o estado de energia das células não permitindo aclimatação e/ou a indução de um metabolismo alternativo antes da condição se tornar letal. WADMAN \& ANDEL (1985) observaram que, após encharcamento repentino, raízes de feijão paralisaram imediatamente o crescimento, permanecendo com peso constante por dois dias, seguindo-se perda de peso, com a maioria morrendo após quatro dias de encharcamento.

Um pré tratamento hipóxico em raízes de milho objetivando a aclimatação aumentou a capacidade de sobrevivência sob anoxia de menos de 10 hs para mais de um dia (SAGLIO et al., 1988). Foi apontado por SACHS et al. (1980) que a elevação gradativa do nível de hipoxia pode resultar em adaptações, como troca no padrão de síntese de proteínas observado em raízes de milho. XIA \& SAGLIO, citados por RICARD et al. (1994), apontam que pontas de raízes de milho aclimatadas não só produziram menos ácido lático mas também o excretaram para o meio resultando em maior $\mathrm{pH}$ do citossol que as não aclimatadas.

Dentre as principais manifestações morfológicas de uma planta sob hipoxia são a epinastia foliar, crescimento de raízes adventícias, hipertrofia das lenticelas e dos caules e produção de aerênquima (JUSTIN \& ARMSTRONG, 1987).

As raízes adventícias tem a função de facilitar a absorção de $\mathrm{O}_{2}$ (SENA GOMES \& KOZLOWSKI, 1980b), tendo sido à elas creditadas uma condutância estomática perto da normalidade em plantas sob encharcamento (SENA GOMES \& KOZLOWSKI, 1980a). Por seu lado, a redução da condutividade estomática é uma das primeiras respostas fisiológicas no encharcamento, tendo sido observado para muitas espécies 
herbáceas (JACKSON \& HALL, 1987). Uma vez alterado, tal sintoma, embora reversível, varia entre as culturas na duração para retornar ao nível normal.

As lenticelas podem funcionar tanto como órgãos de absorção de $\mathrm{O}_{2}$ como depósitos de metabólicos tóxicos (etanol e acetilaldeido) resultante da respiração anaeróbica nas raízes. Juntamente com o aerênquima, funcionam como órgãos de aumento da absorção de $\mathrm{O}_{2}$ e transporte para as raízes (KAWASE, 1981).

Os aerênquimas são espaços contínuos dentro do córtex da planta cuja formação é estimulada pelo etileno DREW \& SISWORO, 1979, visam diminuir a resistividade à translocação de $\mathrm{O}_{2}$ da parte aérea para o sistema radicular. Essas estruturas são tão importantes que plantas que não o desenvolvem, como as ervilhas, pertencem ao grupo de plantas mais sensíveis ao encharcamento. Para 91 espécies de plantas coletadas por JUSTIN \& ARMSTRONG (1987) a extensão do aerênquima desenvolvido foi relacionado com sua resistência ao encharcamento. Afirmam que esses espaços de condução de ar diminui o requerimento de $\mathrm{O}_{2}$ da respiração por unidade de volume de tecido (há menos células respiratórias) e reduz a resistência interna à difusão de $\mathrm{O}_{2}$. Comparações entre raizes de milho com presença ou não de aerênquima foi realizado por DREW et al. (1985) apontando que a presença deste manteve alto o nível de ATP e de carga energética da adenina à grandes distâncias $(30 \mathrm{~cm})$ do ponto de entrada do $\mathrm{O}_{2}$ situado na parte aérea.

Quanto às alterações biológicas, NAWATA et al. (1990), ressaltando a importância, da fixação biológica do nitrogênio, afirmam que a relação entre a bactéria e a resposta da planta ao encharcamento deve ser estudado. Sendo organismos absolutamente aeróbicos, sua sensibilidade à hipoxia tem sido reportado em diferentes 
leguminosas (MINCHIN \& SUMMERFIELD, 1976). Por outro lado, WANG et al. (1993) observaram em soja conduzida em solo saturado que a fixação de $\mathrm{N}$ aumentou, contrariando a expectativa.

Baseado nas considerações acima, há forte evidência de que o adequado manejo do lençol freático, pode vir a se constituir na melhor estratégia de exploração de culturas mesófitas em terras baixas. Assim, teoricamente, um L. F. elevado e estável, imposto logo no início do D. V., poderia induzir a planta ao ajuste automático da parte aérea com a então restrita atividade do sistema radicular. Pesquisa com soja tem mostrado que tal regime pode aumentar de 10 a $20 \%$ a produtividade comparado com a irrigação convencional (NATHANSON et al., 1984). Já uma elevação gradativa do L. F., criaria, seqüencialmente, uma nova e cada vez mais restrita situação de gradiente de $\mathrm{O}_{2}$ e, teoricamente, poderia forçar à novas, porém também, gradativas modificações nos mecanismos adaptativos da planta. Seria racional esperar, em ambos os manejos, que quando da ocorrência de um evento de anoxia temporal (ex. enchente numa várzea) as plantas estariam melhor adaptadas, com maiores chances de sobrevivência.

Em seqüência, estudos tem revelado que o rebaixamento brusco do $L$. F., processo também observado na prática em muitas várzeas, provoca efeitos tão danosos quanto o encharcamento, tanto pelo secamento do solo, prejudicando o sistema radicular já então modificado para condição de solo saturado (raízes adventícias mais porosas e delicadas) como na alteração bioquímica da planta. Segundo MONK et al. (1989) mesmo que as raízes sejam hábeis à sobreviver à anoxia, a inicial re-exposição ao oxigênio pode provocar injurias. A produção de radicais superóxidos em células pósanóxicas causam peroxidação dos lipídeos dos ácidos graxos insaturados da membrana, 
bem como quebra de proteinas, carbohidratos e DNA (CRAWFORD \& BRAENDLE, 1996). Portanto, também no refluxo credita-se uma grande importância à um manejo adequado do L. F.

Fica também inquestionável que, nesta natureza de trabalho, pela intensidade, importância relativa e interatividade que desempenha um grupo de fatores específicos de produção, o perfeito entendimento da performance final de uma cultura mesófita sob hipoxia só é permitido se desenvolvido em condições naturais, sob adequada e sistemática caracterização e monitoramento destes e, daí então, buscar-se interpretar as interações decorrentes.

Assim, os objetivos deste trabalho foram:

- Estudar o efeito de diferentes manejos do L. F. nas principais estruturas adaptativas/mitigadoras da hipoxia bem como a administração da água metabólica, através dos processos de transferência solo/planta/atmosfera utilizadas pelo feijoeiro.

- Caracterizando e monitorando os principais fatores de produção interferentes numa condição de hipoxia, interpretar seu papel individual e interativo na performance final da cultura.

\section{2 - MATERIAL E MÉTODOS}

O experimento foi instalado em delineamento inteiramente casualizado, com quatro tratamentos e cinco repetições.

O efeito dos diferentes manejos do lençol freático (LF) foi estudado através dos seguintes tratamentos: 
$\mathbf{T}_{1}$ - Testemunha; $\mathbf{T}_{2}$ - Igual à testemunha, com elevação e manutenção do L. F. à superficie no fim do florescimento por 7 dias (Teste do grau de adaptação à hipoxia -T.A.H.) - e rebaixamento brusco do lençol freático; $\mathbf{T}_{\mathbf{3}}$ - Elevação e manutenção do L. F a $15 \mathrm{~cm}$ durante todo o estádio vegetativo, aplicação do T.A.H. e rebaixamento gradativo do lençol freático; $\mathbf{T}_{\mathbf{4}}$ - Elevação do L. F a $15 \mathrm{~cm}$, elevação gradativa do L. F. à superfície ao longo do desenvolvimento vegetativo; aplicação do T.A.H. e rebaixamento gradativo do lençol freático.

No $T_{1}$ a cultura foi conduzida em solo aerado, recebendo irrigações subterrâneas, em caráter suplementar, elevando-se o L. F. até a superfície. O "momento da irrigação" foi o potencial hídrico do solo de $0,05 \mathrm{MPa}$, acusado por tensiômetros instalados na profundidade estimada correspondente a $50 \%$ do sistema radicular. Rebaixava-se o L. F. imediatamente após. Esse tratamento representou o potencial máximo produtivo relativo da cultura neste solo e clima. A eficiência da indução adaptativa à hipoxia de cada manejo foi forçada manifestar-se impondo-se, temporariamente, uma condição hipóxica drástica no fim do florescimento, formação de vagens - estádio de maior sensibilidade (GARRITY \& PERNITO, 1996; DINIZ et al., 1993). Sua quantificação foi realizada de modo comparativo entre tratamentos, através dos parâmetros biométricos de performance da cultura, incluindo o rendimento de grãos.

Assim, o $T_{2}$ representou a condição da planta de feijão com adaptação zero, repentinamente submetida ao encharcamento temporário.

Constituiu-se como parcela experimental caixas de cimento amianto de 1000 litros, com área de $1.9 \mathrm{~m}^{2}$ (Figura 16). 
Manejou-se o LF por meio de tubos de 2 polegadas posicionados na base interna das caixas-parcelas, conectados, num sistema de vasos comunicantes, à recipiente adjacente cheio de água, contendo uma bóia hidráulica que exerceu o controle e manutenção do nível da água (no recipiente) e do LF (na caixa-parcela), conforme Figura 16.

O monitoramento do nível do LF foi executado por leitura diária do LF através de poço de observação perfurado no solo e revestido por tubo de PVC perfurado de 2 polegadas. O substrato foi composto de uma camada de brita 1 na altura dos drenos (10 $\mathrm{cm}$ ), seguida de outra camada de mesma espessura de pedrisco e, como solo, $60 \mathrm{~cm}$ de Podzólico Vermelho Amarelo abrupto, A moderado e espesso, textura arenosa, unidade Serrinha (Arenic Abruptic Paleudalt), ácido, de média fertilidade, oriundo de várzea situada no Distrito do Paredão Vermelho, Ártemis, SP. A água utilizada foi de rio, não tratada. A curva de retenção da água no solo é apresentada na Figura 2.
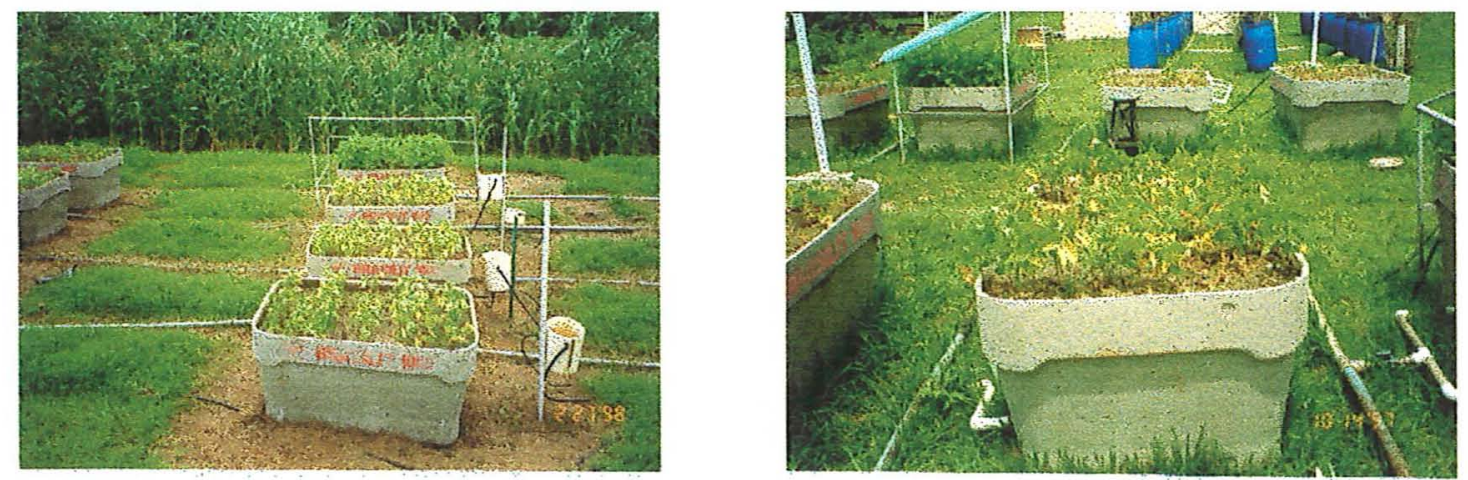

Figura 16. Vista geral do experimento e estruturas de manejo e monitoramento do L. F. Piracicaba, SP, ESALQ/USP. 
A cultivar Bat 477 foi semeada em 25/02/99 após adubação do solo com 90 $\mathrm{Kg}_{\mathrm{g}} \mathrm{ha}^{-1}$ da formulaçấo $4-14-8$, e $30 \mathrm{Kg}^{-h^{-1}}$ de micronutriente FTE, emergindo oito dias após. Procurando-se minimizar a deficiência nutricional decorrente da hipoxia, realizaram-se ainda adubações foliares ao longo do ciclo fenológico.

O L. F. foi elevado a $15 \mathrm{~cm}$ de profundidade no $T_{3}$ e $T_{4}$, aos 13 dias após a emergência (D.A.E).

Procurando checar um possivel super-aquecimento das caixas-parcelas e, portanto, uma descaracterização em relação a um meio físico natural, a temperatura do solo nos $T_{1}$ e $T_{2}$ foi monitorada no estádio vegetativo da cultura, com termômetros de solo instalados a 10 e $20 \mathrm{~cm}$ de profundidade aos 14 DAE em uma das repetições e as leituras foram comparadas com as coletadas numa trincheira, preenchida com o mesmo solo, escavada no terreno adjacente à ela, com a superfície coberta de "muching" simulando cobertura vegetal.

As alterações hídricas no processo de transferência de água no sistema plantaatmosfera foram avaliadas em três oportunidades, à 24 hs e 120 hs após o início da TAH e 96 hs após o seu término. Avaliou-se a da resistência estomática (RE), a taxa de transpiração. a temperatura da folha e a umidade relativa, lidas com porômetro de equilíbrio dinâmico (Licor, modelo Li-1600), utilizando-se a folha mais alta e completamente expandida. Utilizou-se 2 plantas por repetição.

As transformações morfológicas externas foram caracterizadas com lupa observando-se a presença de lenticelas e o número de emissão de raízes adventícias. Para esta última foram desenterradas, cuidadosamente, 2 plantas por parcela, lavadas e, 
após a localização do hipocótilo, efetuado por meio de cortes sistemáticos da raiz principal e observação em microscópio, contou-se, na lupa, o numero de emissões de raízes adventícias.

Para a observação da presença de aerênquimas, utilizou-se microscopia com as lâminas sendo preparadas de modo convencional.

Como parâmetros físico-químicos do meio, antes, durante e nas primeiras horas após o T.A.H. avaliaram-se, em uma parcela do $T_{3}$, em quatro repetições (eletrodos), a alteração temporal da taxa de difusão de oxigênio (TDO) e do potencial redox do solo utilizando aparelho desenvolvido pelo CNPDia/EMBRAPA (HERRMANN et al., 1997). Para tanto, os eletrodos foram instalados a $5 \mathrm{~cm}$ de profundidade, elevando-se, posteriormente, o L. F., num processo de 30 minutos.

Esses parâmetros foram lidos novamente, na mesma profundidade, no penúltimo dia do T.A.H. (144 hs), realizando-se, no entanto, uma leitura em cada parcela.

Auxiliando ainda as interpretações dos parâmetros físico-químicos acima descritos, mediu-se, gravimetricamente, o grau de saturação do solo dos tratamentos $\mathrm{T}_{3}$ e $\mathrm{T}_{4}$, imediatamente antes o T.A.H., coletando-se uma amostra por parcela, a $20 \mathrm{~cm}$ de profundidade.

No $7^{\circ}$ dia do T.A.H., também nos tratamentos $T_{3}$ e $T_{4}$, avaliou-se o lençol freático, quantificando o conteúdo de oxigênio dissolvido, $\mathrm{pH}$ e temperatura através do aparelho Aquacheck da Radelkis Eletronical Instruments, realizando-se uma leitura por repetição, entre as 7:30 e 10:00 hs da manhã, a $5 \mathrm{~cm}$ de profundidade do L. F.

Os parâmetros biométricos de desenvolvimento foram avaliados imediatamente antes do T.A.H. e os parâmetros de produção na colheita utilizando, em ambas, duas 
plantas por repetição, com exceção do rendimento de grãos, que correspondeu a amostragem em duas fileiras centrais de 1,0 m de comprimento.

As análises estatísticas foram realizadas através da análise de variância $(\mathrm{P}<$ 0,05), teste de significância de Tukey e Duncan, a $5 \%$ e determinação do Erro Padrão.

\section{3 - RESULTADOS E DISCUSSÃO}

\subsection{1 - Parâmetros climáticos e particularidades do manejo executado: A ocorrência} de temperaturas em torno de $27^{\circ} \mathrm{C}$ tornou o periodo vegetativo e de início adaptativo à hipoxia ainda mais difícil para as plantas por terem que conciliar um sistema radicular pouco efetivo, em processo de modificação/adaptação, com a satisfação da alta demanda transpirométrica (Figura 17A).

No período seguinte, envolvendo a aplicação do T.A.H., ocorreu o decréscimo da temperatura, juntamente com uma seqüência de precipitações. Este fato, com a decorrente elevação da UR\% do ar, sem duvida, contribuiu para minimizar o impacto do T.A.H. em função da diminuição da taxa transpirométrica, beneficiando, principalmente, o $T_{2}$ que, por não ter sido induzido à adaptação à hipoxia, estaria apresentando maior dificuldade na absorção de água.

A temperatura continuou sendo benéfica no período pós a T.A.H. por ter se estabilizado num patamar de, aproximadamente, $7^{\circ} \mathrm{C}$ inferior ao período anterior (vegetativo).

Seis dias após a elevação do lençol freático a $15 \mathrm{~cm}$ de profundidade nos $T_{3}$ e $T_{4}$, observaram-se os primeiros sintomas de leve clorose em algumas plantas e ligeira epinastia nas horas mais quentes do dia, prolongando-se assim até o $13^{\circ}$ dia da elevação 
do lençol, quando os dois tratamentos já apresentavam $50 \%$ das plantas com as folhas de baixo amareladas. Sintomas idênticos (murchamento foliar, principalmente as velhas, seguido de amarelec:mento, secamento e morte da planta inteira), foram observados, já no terceiro dia de encharcamento, por GARRITY \& PERNITO (1996), trabalhando com feijão Mungo (Vigna radiata, L.).

A diferenciação do manejo do L. F. entre o $T_{3}$ e o $T_{4}$ ocorreu a partir do $10^{\circ}$ D.A.E.L.F com o início da elevação gradativa do L. F. no $T_{4}$, resultando, à partir desse dia até a TAH, um período de 18 dias de LF mais elevado que o $T_{3}$, num máximo de 8 cm. O rebaixamento do L.F. nesses dois tratamentos foi executado numa mesma intensidade, gradativamente, passando de superficial a ausência de LF em 20 dias, coincidindo o seu término a 5 dias após o aparecimento dos primeiros sintomas de senescência. Já no $T_{2}$ o processo de rebaixamento do L.F. foi brusco, executado em 1 dia (Figura 17B).

A avaliação clas diferenças de temperatura do solo da caixa e o solo do terreno, em duas profundidades e em diferentes dias e horários (figuras 18A e B), apontaram que, na parte da manhã, nas duas profundidades, as temperaturas do solo foram menores na caixa que no terreno. Provavelmente isso é função do horário de leitura uma vez que o sistema-caixa tende a perder mais calor durante a noite que o sistema no terreno alem deste último ter apenas uma face de transferencia de calor para a atmosfera, recebendo à noite, ainda, energia do meio circundante. À tarde esta tendência se inverte, provavelmente em função da maior exposição do sistema caixa/solo ao aquecimento pelo sol. De qualqueı forma, pelo fato das diferenças máximas, na manhã, terem sido de $2.2{ }^{\circ} \mathrm{C}$ a $5 \mathrm{~cm}$ e, não superior a $1{ }^{\circ} \mathrm{C}$ a $25 \mathrm{~cm}$, e; à tarde, nas duas profundidades terem sido, no máximo de $1^{\circ} \mathrm{C}$, pode-se inferir que o sistema de caixas de cimento amianto 
não teve, na temperatura do solo, um fator significativo de descaracterização de um meio natural.

5.3.2 - Parâmetros biométricos da parte aérea: Fenológicamente, o inicio do florescimento ocorreu sem diferença entre os tratamentos, bem como a formação de vagens. Aos 22 dias após a elevação do lençol a $15 \mathrm{~cm}$, era nítido um gradiente na altura das plantas, crescente do $T_{4}$ e $T_{3}$ para os $T_{2}$ e $T_{1}$ (Tabela 2).

As alturas de plantas no $\mathrm{T}_{3}$ e no $\mathrm{T}_{4}$ foram $70 \%$ e $76 \%$ do $\mathrm{T}_{1} / \mathrm{T}_{2}$, respectivamente, significativamente diferente $(\mathrm{P}<0,05)$.

A tendência de maior altura de planta no $T_{4}$ que no $T_{3}$ deve-se a um maior estiolamento do caulı e não ao vigor adaptativo, como demostra a massa da parte aérea. Isso também fica ciaro nos demais parâmetros biométricos onde, por exemplo, o número de folhas (NF) foi menos de $50 \%$ no $T_{4}$ em relação ao $T_{1}$ contra $92,5 \%$ no $T_{3}$ com diferença significativa, inclusive, entre o $\mathrm{T}_{4}$ e $\mathrm{T}_{3}$.

Estas observeções são concordantes com TAKELE \& MCDAVID (1994), que trabalhando com feijão Caupi (Vigna unguiculata, L. Wapp) observaram que a taxa de acúmulo do pecíolo $\left(\mathrm{g} \mathrm{m}^{-2} \mathrm{dia}^{-1}\right.$ ) foi aumentado com o nível de encharcamento.

O menor vigor vegetativo do $T_{3}$ e $T_{4}$ em relação ao $T_{1} / T_{2}$ apresentados em todos os parâmetros biométricos de crescimento avaliados pode ser interpretado tanto como 

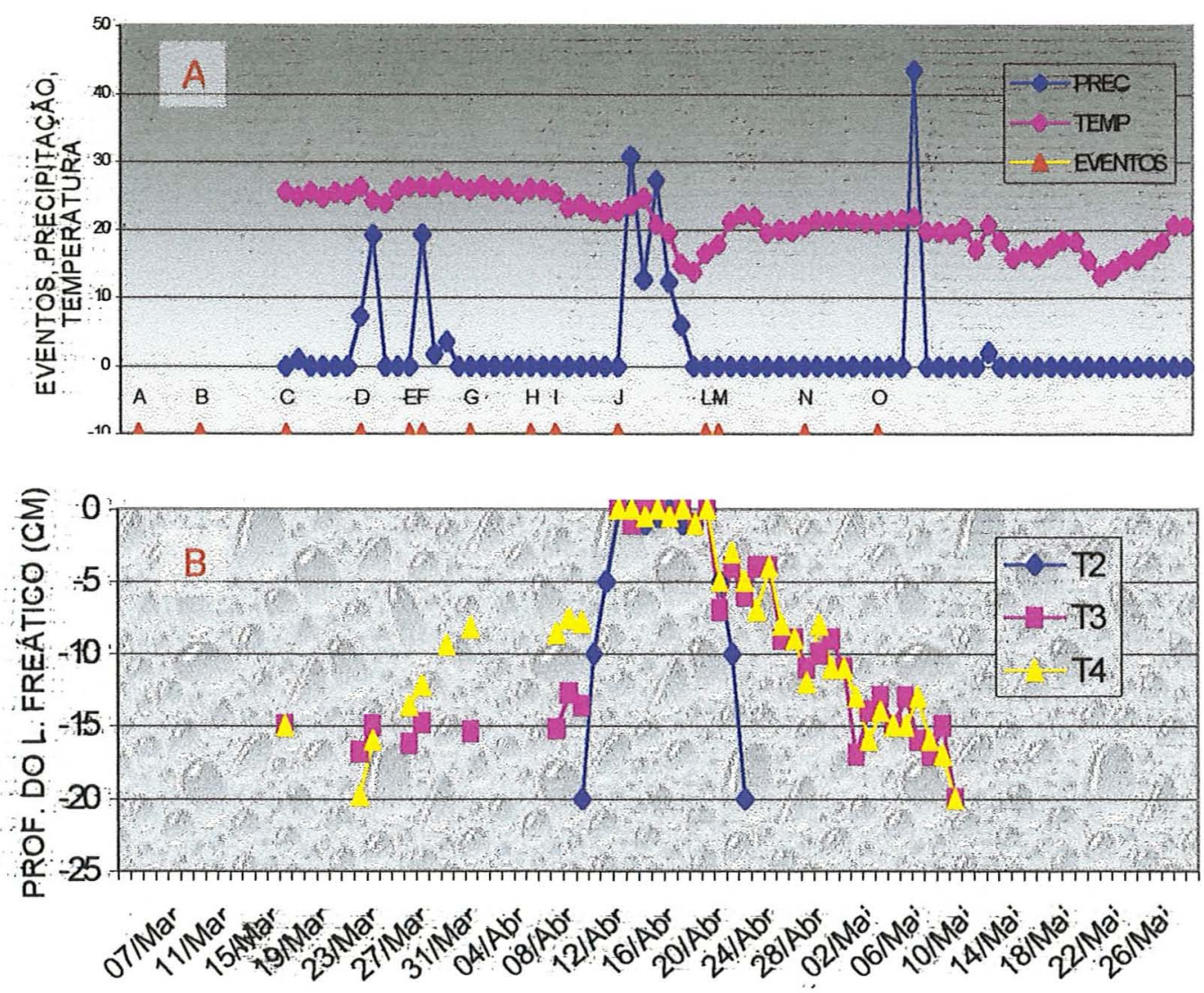

DATA

A Emergênoia:

B 6 D.A.E.; irrigação subterrânea de estabeleci/to..

C 13 D.A.玉, 2 pares détrifólios; elevação do L: F. a $15 \mathrm{~cm}$.

D 19 D.A.E., $1^{\text {os }}$ sintomas leves de elorose e epinastia no. $T_{3}$ e $T_{4} ; 1^{\circ}$ adubação foliar; altura das plantas de 17 a $20 \mathrm{em}$ :

E 23 D.AE, 4 pares de trifólios; altura das plantas 30 : $\mathrm{cm}$;

Điferenciaçã̃o entre os trat/tos $\mathrm{T}_{3} \mathrm{e} \mathrm{T}_{4}$.

F 24 D.A.E., $1^{\circ}$ s flores em todos tratamentos.
G 28 D.A.E., sintoma nítido de clorose, epinastia e folhas de baixo. amarelas no $\mathrm{T}_{3}$ e $\mathrm{T}_{4}$.

- $\mathrm{H}$ : 33 D.A.E., irrigação do' $\mathrm{T}_{1}$ ' e $\mathrm{T}_{2}$

I $35^{\circ}$ D.A.E., 22 dias após a elevação do: L.F (D.A.E.L.F.); fenologia normal (floração e formação de vagem), com sintomas nítidos de hipoxia; análise biométrica de desenvolvimento.

J - 40.D.A.E. inicio da T.A.H

L 47.D:A.E., fim da T.A.H.

M 48 D.A.E., $2^{\circ}$.adubação foliar

N 55 D.A.E., $2^{\circ}$ irrigação do $T_{1}$

O 61 D.A.E., início da senescência

Figura 17: (A) Sequêencia de eventos, precipitação (mm) e temperatura média $\left({ }^{\circ} \mathrm{C}\right)$ ocorridos ao longo do ciclo fenólógico do feijoeiro, (B) Flutuação do L: $\mathbf{F}$ : ocorrida durante o ciclo fenológico da cultura do feijão. Piracicaba, SP, ESALQ/USP: 

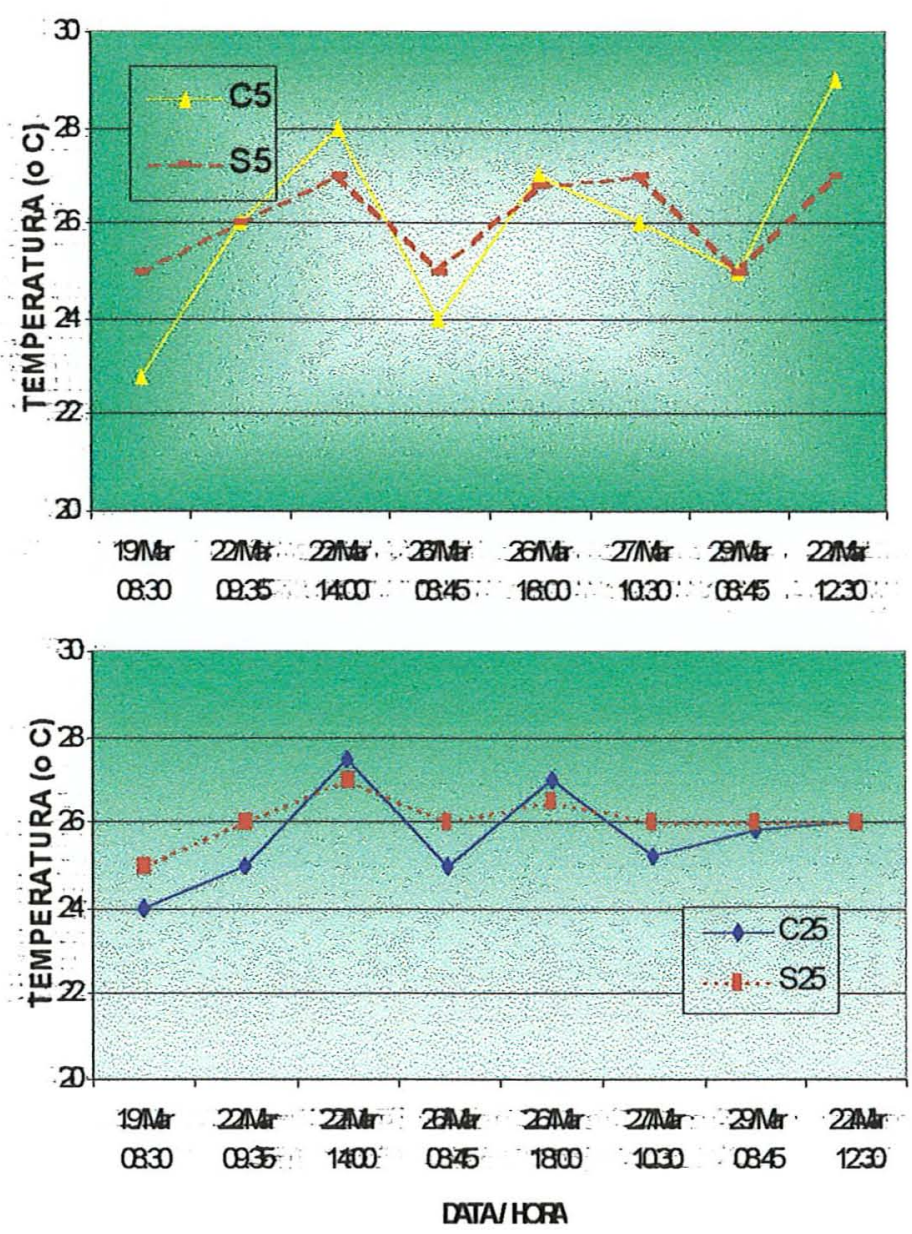

Figura 18 . Diferença entre as temperaturas do solo a $5 \mathrm{~cm}$ e a $25 \mathrm{~cm}$ de profundidade na parcelä (c) e:o solo do terreno (s):

resultado da deficiente taxa metabólica imposta à planta e/ou, comparando-se o $\mathrm{T}_{4} \mathrm{com}$ o $T_{3,}$ : como de um gasto de energia adicional para formação : de oportunas raízes adventícias: O parâmetro massa das vagens pode também ter recebido a:mesma natureza de interferência:

A redução na área foliar e no numero de follhas deve ser interpretado como aumento da abscisão foliar, sendo apontados como uma resposta comum ao encharcamento por TAKELE \& MCDAVID (1994). Concordantes, WADMAN \& VAN 
ANDEL (1985) observaram paralisação total no crescimento foliar do feijão após 24 hs de encharcamento, enquanto SINGH et al. (1991), também no feijão, atribuíram o baixo numero de folhas e área foliar à senescência e queda das largas e mais velhas folhas de baixo.

Se a proporçč.o de decréscimo da $A F$ do $T_{4}$ para o $T_{1}$ foi relativamente próxima da apresentada pelo numero de folhas (39\% e $47 \%$, respectivamente), isso já não ocorreu do $T_{3}$ para $\circ T_{1}$ - decréscimo de 33,2\% na área foliar e apenas 7,52\% no numero de folhas. Isso evidencia um alto efeito do manejo no parâmetro AF e, por outro lado, a não aplicabilidade do parâmetro número de folhas na avaliação do efeito da hipoxia, pelo menos, nesse nível de manejo (restrição) imposto.

5.3.3 - Adaptações morfológicas de trocas gasosas: A formação de raízes adventícias foi expressiva (Figura 19). A contagem do numero de raízes adventícias realizada 24 dias após a elevação do lençol a $15 \mathrm{~cm}$ (Figura 19D) apresentou, no $T_{3}, 25,9$ emissões (Figura 19E) a mais que no $T_{1}$. Indubitavelmente, esses $114 \%$ a mais pode ser atribuído ao estímulo do manejo do L. F. empregado. No $\mathrm{T}_{4} \mathrm{o}$ numero de raízes adventícias foi ainda maior - $241 \%$ a mais que o $\mathrm{T} 1$. Interpreta-se que neste manejo, a cada gradativa elevação do L. F, coi permitido às plantas, um tempo de readaptação do sistema radicular, levando-o à produzir, ainda, 59\% a mais que o $\mathrm{T}_{3}$. TAKELE \& MCDAVID (1994), comparando diferentes cultivares de feijão Caupi (Vigna unguiculata, (L) Walp) sob encharcamento. observaram que a diferença entre as cultivares no número de raízes secundárias que as plantas conseguem manter e a 

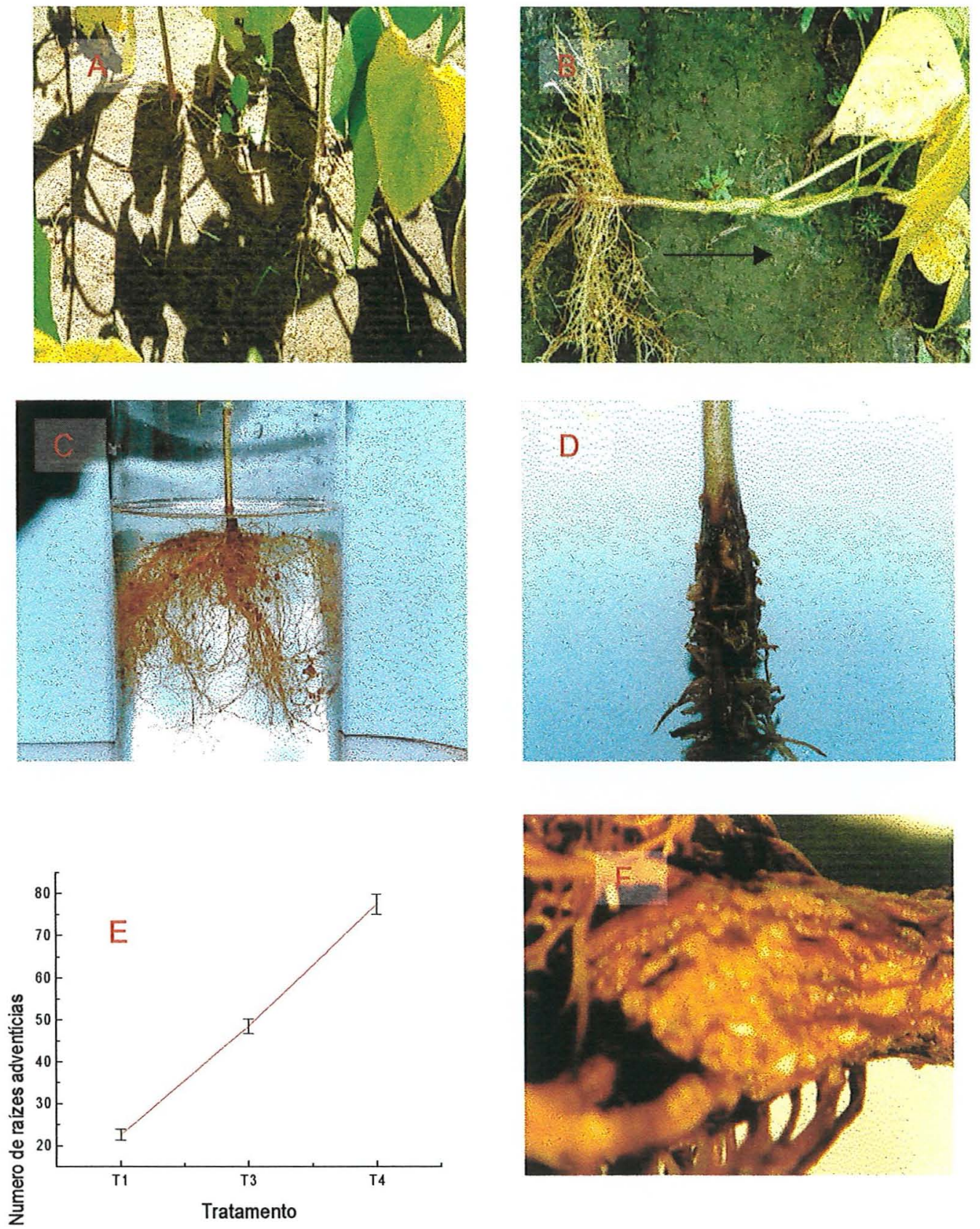

Figura 19. (A) Desenvolvimento superficial de raízes adventícias (B e C) Profusão de raízes adventícias na parte basal do colo; (D) Padrão de emissão de raízes adventícias; (E) numero de raízes nos diferentes tratamentos; (F) tecido esponjoso facilitador da penetração de $\mathrm{O}_{2}$ na base do caule. 
extensão e distribuição de aerênquima pode ser um dos fatores determinantes à sua relativa tolerância ao encharcamento. Observou-se também rompimento da epiderme com o aparecimento de um tecido esponjoso (Figura $19 \mathrm{~F}$ ) que são, na realidade, orifícios facilitadores de penetração de $\mathrm{O}_{2}$, segundo KAWASE, 1981.

A presença de aerênquima no córtex das raízes adventícias também foi observada. (Figura 20)
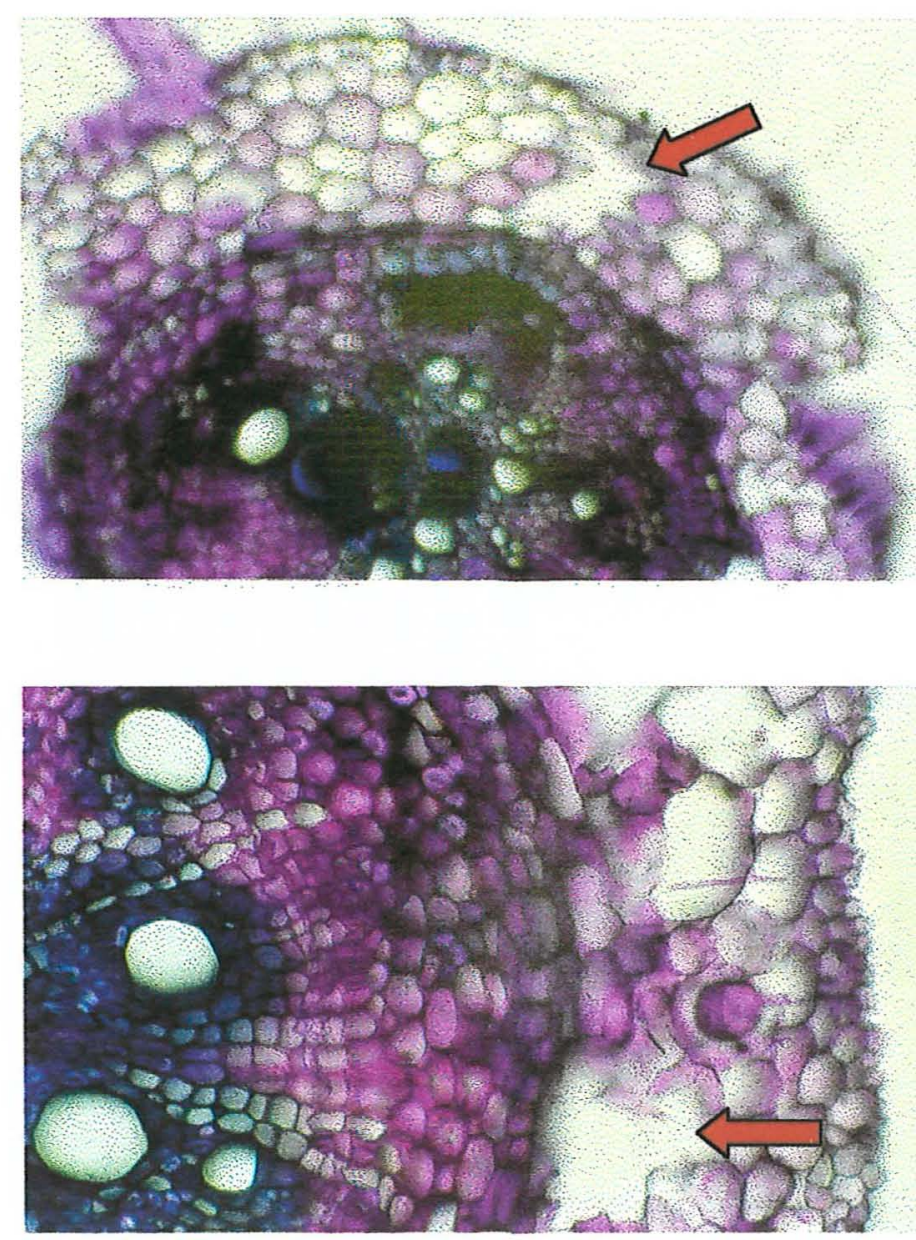

Figura 20. Formação de aerênquima (seta) no córtex das raízes adventícias do feijão sob encharcamento. Cortes executados nas raízes de plantas do $\mathrm{T}_{4}$. Piracicaba, SP, ESALQ/USP. 
Observou-se nítidos espaços no córtex (Figura 20) formados pela lise de paredes celulares, originando os aerênquimas.
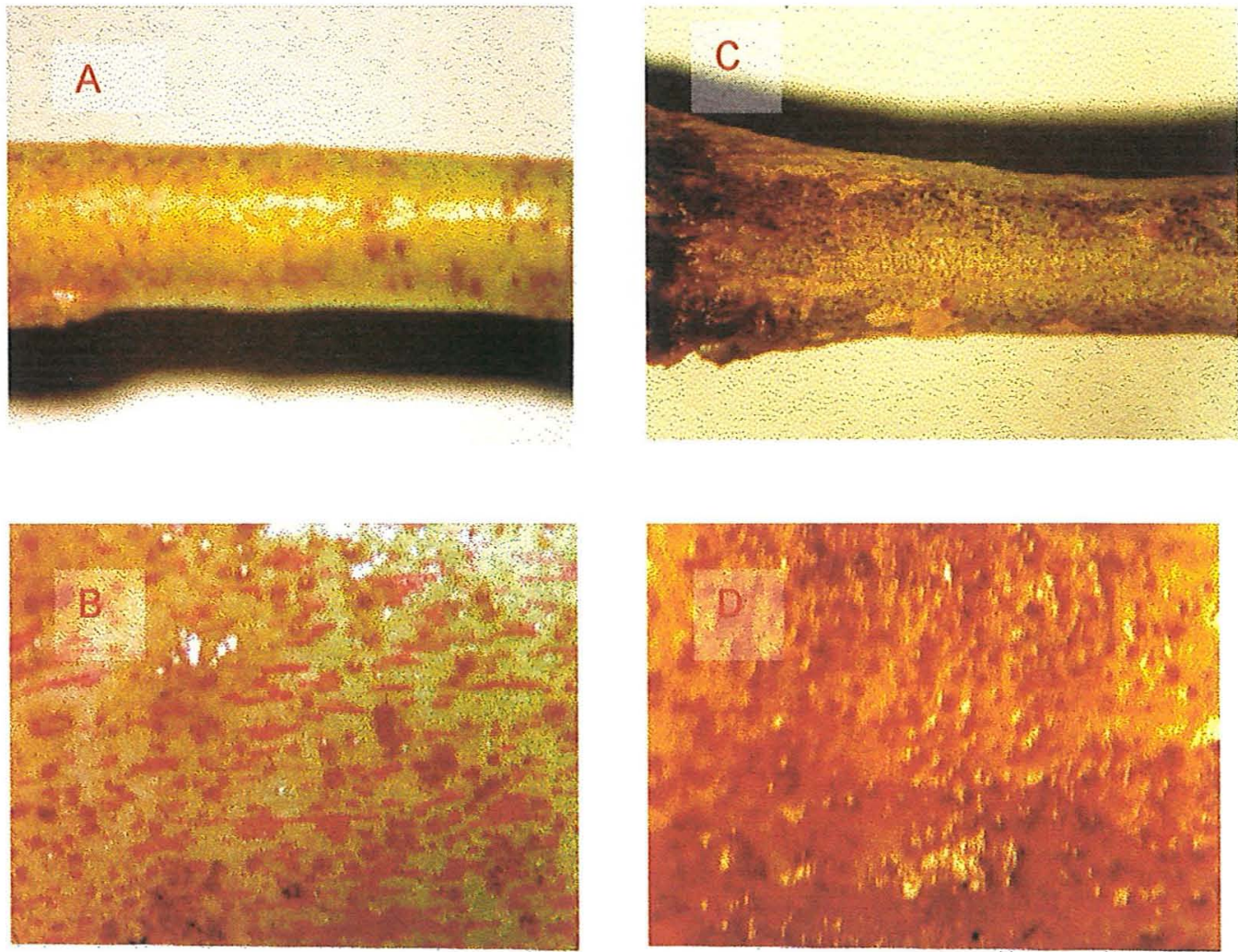

Figura 21. Formação de lenticelas na base do caule no (A e B) $T_{1}-$ Testemunha e no (C e D) $\mathrm{T}_{4}$ - Elevação gradativa do L.F. Piracicaba, SP, ESALQ/USP. 
A ação do etileno na formação de aerênquimas foi comprovado por KAWASE (1978) em diferentes: culturas. Explica que a deficiência de oxigênio leva à formação anaeróbica do etileno, causando um incremento na atividade da enzima celulase, resultando na formação de aerênquima, que, por sua vez, facilitam o transporte de gases. É comum o desenvolvimento de aerênquima, originados pelas células colapsadas, simultaneamente com o alargamento radial das células no córtex. O fato de células colapsadas e alargadas ocorrerem lado a lado sugere que as colapsadas podem ser resultado de compet ção entre as células corticais por água, após as paredes celulares terem se fragilizados pela atividade da celulase.

Nos tratamentos de hipoxia também houve um estimulo à formação de lenticelas na base do caule, observadas em maior densidade nos tratamentos hipóxicos quando comparados com o $\mathrm{T}_{1}$ (Figura 21).

A presença e a intensidade dessas três estruturas comprovam a busca efetiva de mecanismos adaptativos do feijoeiro à hipoxia.

5.3.4 - Fixação biclógica do nitrogênio: A umidade do solo no $T_{4}$, a $5 \mathrm{~cm}$ de profundidade e imediatamente antes do T.A.H. (Tabela 1), de acordo com a curva de retenção (Figura 2), apresentava, uma completa saturação. Nesse dia, o L. F. estava a $7 \mathrm{~cm}$ de profundidade. Já no $T_{3}$, com o L. F. estabilizado em $15 \mathrm{~cm}$, o grau de saturação era ligeiramente menor, apresentando $1,3 \%$ de poros livres de água. Embora estes valores indiquem, alta restrição de oxigênio, surpreendentemente, não impediram o desenvolvimento de rizóbio na planta (Figura 22A).

Ocorre que, também na própria busca à adaptabilidade, aproveitando-se da emissão e desenvolvimento de raízes adventícias superficiais situadas na interface 
solo/atmosfera $\mathrm{e}$, portanto, com uma rizosphera teoricamente menos hipóxica, (Figura $19 \mathrm{~A}$ e B), acrescido dos benefícios do suprimento interno de $\mathrm{O}_{2}$ via estruturas de translocação morfologicamente modificadas, já discutidos anteriormente, estes organismos encontraram condição um pouco menos crítica e se desenvolveram. $\mathrm{O}$ observado é concorciante com JUSTIN \& ARMSTRONG (1987). Afirmam haver um apreciável numero de espécies de solo encharcado que, embora não formem aerênquima, executam o desenvolvimento de raízes superficiais na delgada zona aeróbica em contato som a atmosfera.

Estudando detalhadamente o nódulo desenvolvido sob encharcamento (figura 22D), observa-se uma modificação morfológica na sua superfície, não presente nos nódulos desenvolvidos em condição de normoxia. Essas modificações também foram apontadas por HONG et al. (1977), indicando que podem estar relacionadas à formação de lenticelas.

Quanto à sua atividade pode ser inferida indiretamente se considerar-se a afirmação de MICHIN \& SUMMERFIELD (1976) de que a presença de bacterióides no centro dos nódulos de feijão Caupi (Vigna unguiculata, L. Walp) inundado por 32 dias fornece fortes evidencias da continuidade de suplemento de oxigênio para esses tecidos.

A interação entre o manejo do LF com as particularidades da fixação biológica é de fundamental importância. Isso não foi respeitado por HONG et al. (1977), cujos resultados com feijão caupi foram opostos aos aqui obtidos. Apontam que o peso seco dos nódulos durante o período de encharcamento decresceu em $31 \%$ no $32^{\circ}$ dia do ciclo da cultura, comparaco com valores registrados imediatamente antes do encharcamento, $\operatorname{aos} 24^{\circ}$ dia do ciclo cultural e em $70 \%$ comparado com a testemunha quando ambas 

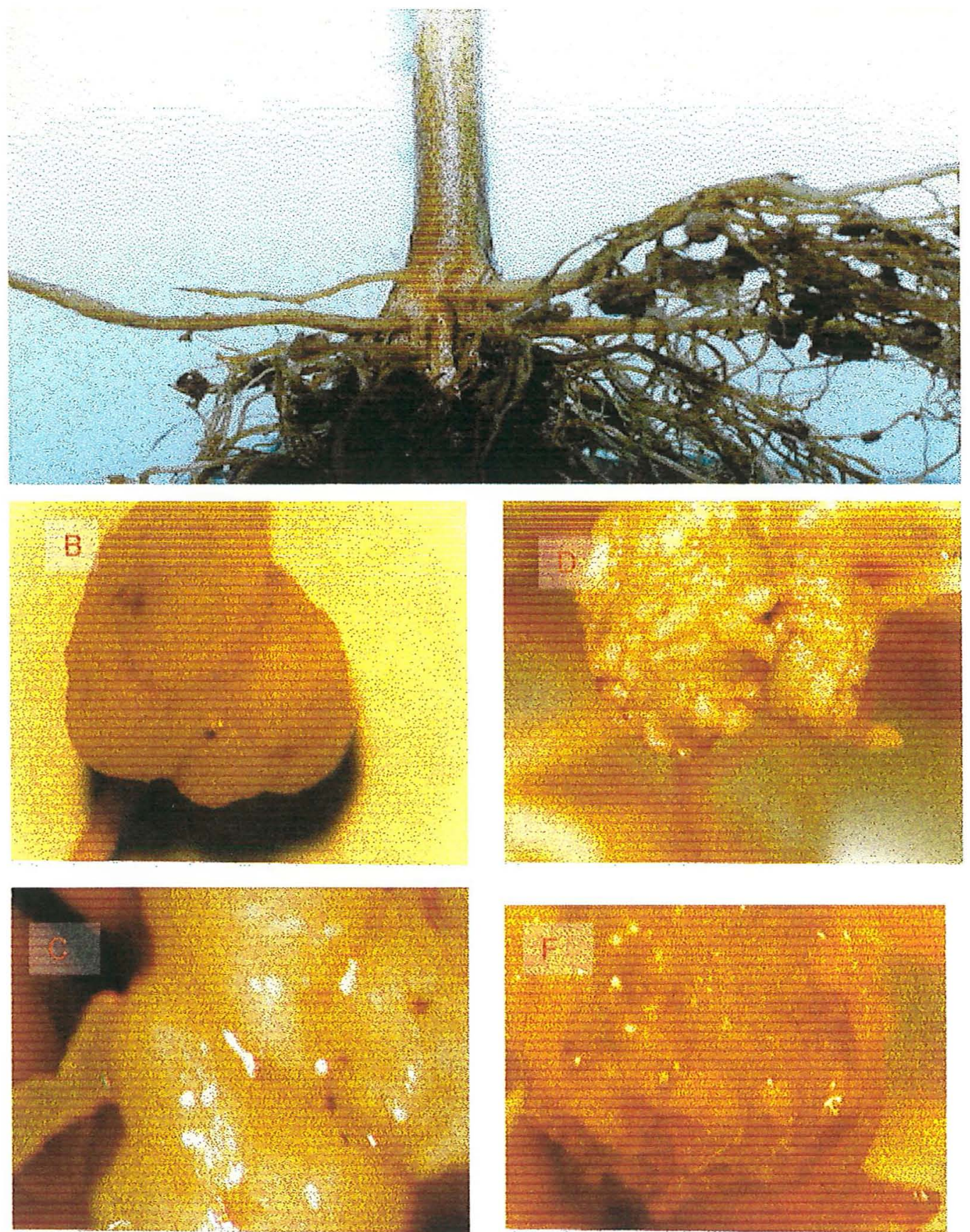

Figura 22. (A) Formação de nódulos fixadores de $\mathrm{N}$ atmosférico em feijão sob encharcamento; ( $\mathrm{B}$ e $\mathrm{C}$ ) nódulo do $\mathrm{T}_{1}$, ( $\mathrm{D}$ e $\mathrm{F}$ ) nódulo do $\mathrm{T}_{4}$, com estruturas modificadas na superficie. Piracicaba, SP, ESALQ/USP. 
estavam aos $32^{\circ}$ dia do ciclo cultural. A inundação abrupta, sem uma preparação da planta e do hospedeiro através de um adequado manejo do lençol pode ser apontado como o responsável pelo insucesso.

Assim, em plantas submetidas à hipoxia, não tem sentido medir-se somente a nodulação. A dinâm ca de emissão de raizes adventícias deve ser atentada pois, como mostra este trabalho, a gradativa substituição de raizes normais pelas adventícias exercerá um efeito direto na efetividade da fixação simbiótica.

5.3.5 - Alterações de parâmetros físicos do solo: Voltando-se à análise da umidade do solo no período anterior ao T.A.H. no $\mathrm{T}_{4}$, em que o L. F. a $7 \mathrm{~cm}$ de profundidade condicionava o horizonte de maior concentração de raízes do feijão à condição de completa saturação, praticamente anoxia (Tabela 1) e que, até mesmo o $\mathrm{T}_{3}$, com o L.F. a $15 \mathrm{~cm}$, apresentavai-se com apenas $1,3 \%$ de poros livres de água, se for hipotizado o potencial produtivo do feijoeiro baseando-se, exclusivamente nesse parâmetro, seguramente, é nenhum.

DINIZ et al., (1993) estudando diferentes níveis de água no solo para avaliação de cultivares de feijoeiro para cultivo em várzea, apontaram que o nível de água no solo que possibilitou a produção máxima de grãos/planta ficou compreendida entre 40 e $60 \%$ de volume de poros livres de água, extremamente acima, portanto, das condições impostas nesse trabalho.

Caracterizando a dinâmica do $\mathrm{O}_{2}$ no perfil do solo, observa-se que a flutuação da 
TDO durante a elevação do L. F., (8A), após um decréscimo, estabilizou-se após 2,5 horas num patamar em torno de $12.10^{-8}\left(\mathrm{~g} \mathrm{~cm}^{-2} \mathrm{~min}^{-1}\right)$, permanecendo assim até a $8^{0}$ hora de amostragem. Seguidamente, após 145 hs de encharcamento, apresentou-se em torno de $5.10^{-8}\left(\mathrm{~g} \mathrm{~cm}^{-2} \mathrm{~min}^{-1}\right)$. Considerando-se STOLZY \& LETEY (1964) que apontam uma TDO de $20.10^{-8} \mathrm{~g} \mathrm{~cm}^{-2} \mathrm{~min}^{-1}$ inibidora do crescimento radicular de numerosas espécies herbáceas, pode-se avaliar, também por esse parâmetro, o grau de restrição a que estavam expostas as plantas. Também pode ser avaliado o grau restritivo considerando-se que plantas nativas, desenvolvendo-se em condições naturais de áreas úmidas, portanto, teoricamente, perfeitamente adaptadas ao meio hipóxico, foram associadas com TDO entre $5.10^{-8} \mathrm{~g} \mathrm{~cm}^{-2} \min ^{-1}$ a $25.10^{-8} \mathrm{~g} \mathrm{~cm}^{-2} \mathrm{~min}^{-1}$ (POEL, 1960).

Observa-se também decréscimo do potencial redox, tendo atingido um ponto mínimo, logo na $4,5^{\circ}$ hora de hipoxia, elevou-se gradativamente, atingindo um ponto intermediário (-220 mV) após 145 hs (Figura 23B).

Essa elevação poderia ser atribuída à grande quantidade de algas, presentes na superfície do solo ar.tes da aplicação da TAH, e que, à partir do T.A.H., teoricamente, encontraria condição ainda mais favorável ao seu desenvolvimento. Não foi identificado o tipo de alga, nem tampouco pode-se inferir quanto a sua contribuição em $\mathrm{O}_{2}$ para $\mathrm{o}$ meio.

A porcentagem de oxigênio dissolvido na água do estrato de saturação do solo, avaliada no último dia do T.A.H., apontava valores acima de 100\% de saturação (Tabela 12), também atribuída às algas o que estaria compatível com a TDO e o potencial redox lidos à, aproximadamente, 6 dias (145 hs) da implantação do T.A.H. A presença desses organismos podem também justificar o maior conteúdo de $\mathrm{O}_{2}$ no $T_{4}$ que no $\mathrm{T}_{3}$ por este 
ultimo ter permanecido com menor grau e tempo de alta umidade na superfície do solo e assim, menor presença de algas com consequentemente menor contribuição em oxigênio.
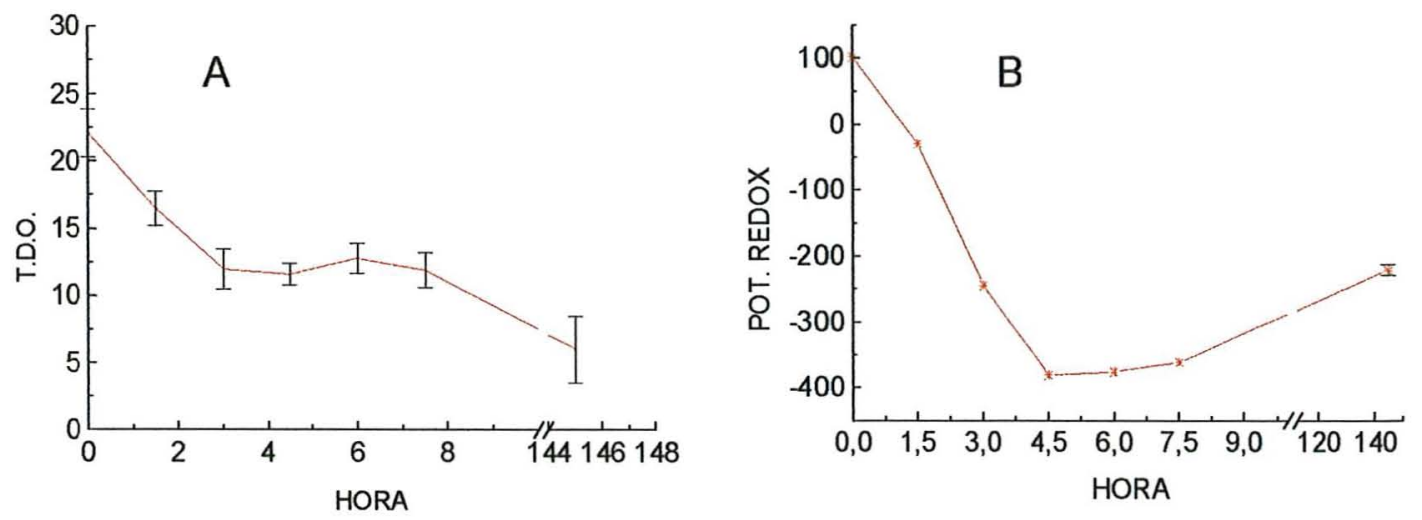

Figura 23. A) Variação da taxa de difusão de oxigênio $\left(\mathrm{g} . \mathrm{cm}^{-2} \cdot \mathrm{min}^{-1} \cdot 10^{-8}\right)$, com média e erro padrão $n=4$ e; B) Variação do potencial redox $(\mathrm{mV})$ durante a elevação do L. F. Piracicaba, SP, ESALQ/USP.

Com muita reserva, poderia-se inferir que este maior conteúdo de $\mathrm{O}_{2}$ da água no $\mathrm{T}_{4}$ estaria refletindo, nesta data, na resistência estomática, à ser discutido posteriormente. Observa-se que a concentração de $\mathrm{O}_{2}$ nos dois tratamentos, não é mais que $5 \%$ da concentração de oxigênio do ar atmosférico, o que corresponderia também ao de um solo, considerando-se que a concentração de $\mathrm{O}_{2}$ do solo aerado é próxima do ar atmosférico (LINDSTROM, citado por DREW, 1992).

Analisando-se o nível das temperaturas do lençol freático, lidas no $\mathrm{T}_{3}$ e $\mathrm{T}_{4}$, pode-se considera-las altamente desfavoráveis à planta sob hipoxia em função da menor capacidade de saturação de $\mathrm{O}_{2}$ da água do solo. Além disso, o que é mais crítico, eleva a taxa de consumo de $\mathrm{O}_{2}$. Pode-se avaliar o que representa esse particular, comparando-se 
com o observado por CANNELL et al. (1980), em trigo, sob temperaturas de solo muito mais amenas. Relatam que, com temperatura de $4{ }^{\circ} \mathrm{C}$ a $20 \mathrm{~cm}$ de profundidade, o $\mathrm{O}_{2}$ do solo esgotou-se em 13 dias, em contrate com o esgotamento completado em apenas 5 dias. quando sob $11-12^{\circ} \mathrm{C}$.

Tabela 12. Nível de saturação do solo e análise do extrato de saturação do solo, do recipiente de distribuição e da caixa de abastecimento no $7^{\circ}$ dia $(168 \mathrm{hs})$ de T.A.H., avaliadas a $5 \mathrm{~cm}$ de profundidade. Piracicaba, SP, ESALQ/USP.

\begin{tabular}{|c|c|c|c|c|c|c|c|c|c|c|c|c|}
\hline \multirow{3}{*}{ TRAT } & \multicolumn{7}{|c|}{ SOLO } & \multicolumn{5}{|c|}{ ÁGUA } \\
\hline & U. Vol. & oXIG. & T. & $\mathrm{C}_{2} \mathrm{O}_{2} \mathrm{~S}$ & $\mathrm{CCO}_{2} \mathrm{EXT}$ & C. $\mathrm{O}_{2}$ A. A. & $\mathrm{pH}$ & OXIG. & $\mathrm{T}$ & C. $\mathrm{O}_{2}, \mathrm{~S}$ & C. $\mathrm{O}_{2} \mathrm{R}$. & $\mathrm{pH}$ \\
\hline & $\mathrm{cm}^{3} \cdot \mathrm{cm}^{-3}$ & $\%$ & ${ }^{\circ} \mathrm{C}$ & mg.dm ${ }^{-3}$ & $\mathrm{mg} \cdot \mathrm{dm}^{-3}$ & mg.dm ${ }^{-3}$ & & $\%$ & ${ }^{\circ} \mathrm{C}$ & mg.dm ${ }^{-3}$ & mg.dm & \\
\hline $\mathrm{T} 3$ & $0,35(0,004)$ & 123,2 & 21,0 & 8,85 & $10,8(0,4)$ & 272 & $5,9(0,6)$ & 132 & 20 & 9,0 & 11,90 & 7,7 \\
\hline T4 & $0,39(0,006)$ & 150,4 & 22,6 & 8,54 & $12,8(0,4)$ & 267 & $6,04(0,5)$ & 143 & 28 & 7,7 & 11,03 & 8,0 \\
\hline R.C.N & & & & & & & & 84 & 23 & 8,5 & 7,14 & 6,7 \\
\hline
\end{tabular}

R.C.N. Recipiente de cortrole de nivel

C. $\mathrm{O}_{2}$ S. - Conteúdo de Oxigênio dissolvido na água saturada com ar em função da temperatura.

C. $\mathrm{O}_{2}$ EXT. - Conteúdo do oxigênio dissolvido no extrato de saturação do solo (sem correção de pressão atmosférica e sais dissolvidos na água.

C. $\mathrm{O}_{2}$ A. A. - Concentraç̂̀. de oxigênio em ar atmosférico saturado com água na temperatura média da avaliação (Glinski \& Stepniewski, 1985).

$(0,4)$ - Erro padrão.

\subsection{6 - Transformações fenotípicas ocorridas durante o teste de adaptação à} hipoxia (T.A.H.).

O efeito sequiencial do encharcamento no fenótipo do feijão é apresentado na figura 24. 

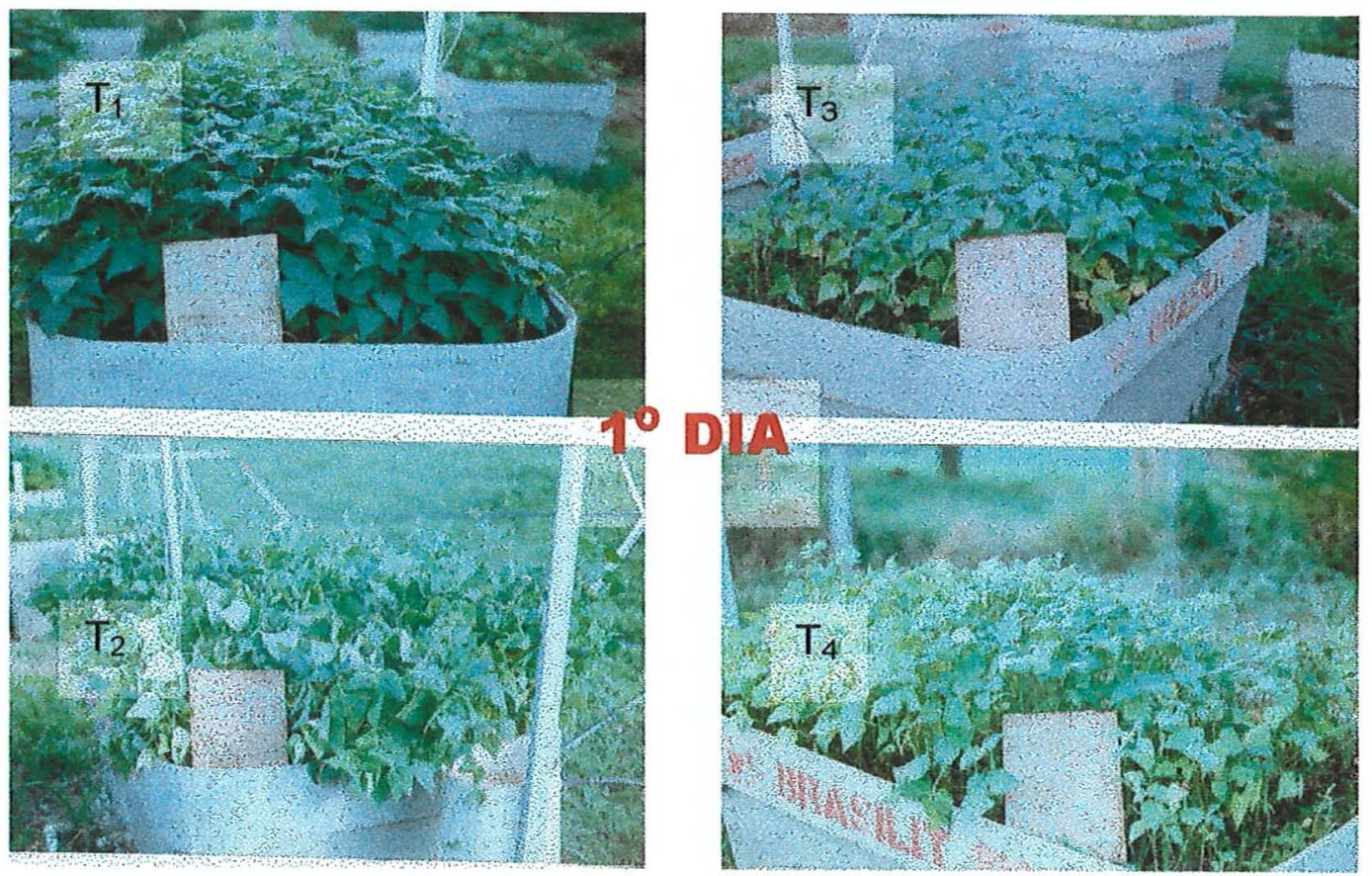

D) $1 /$
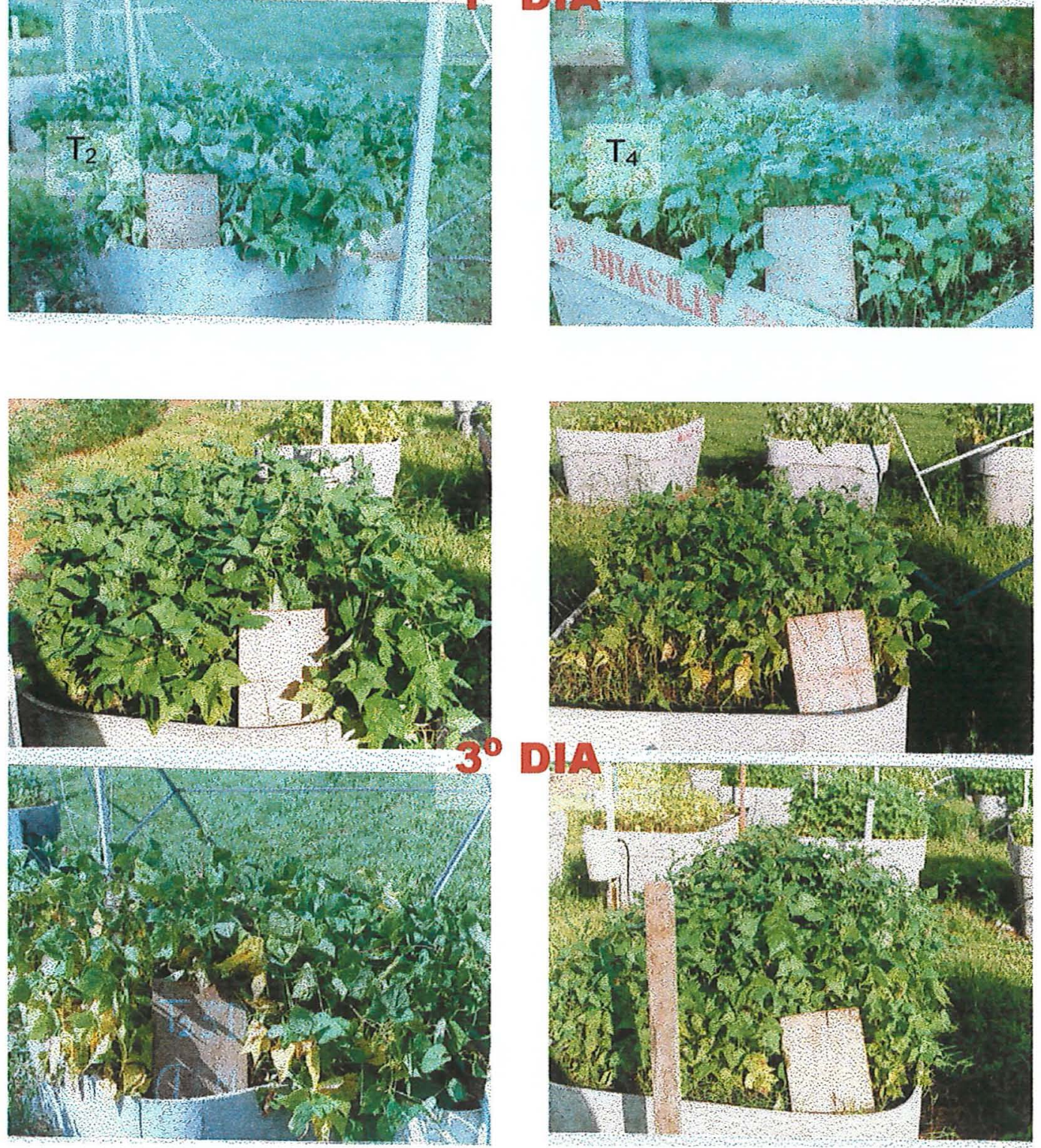

D.I.

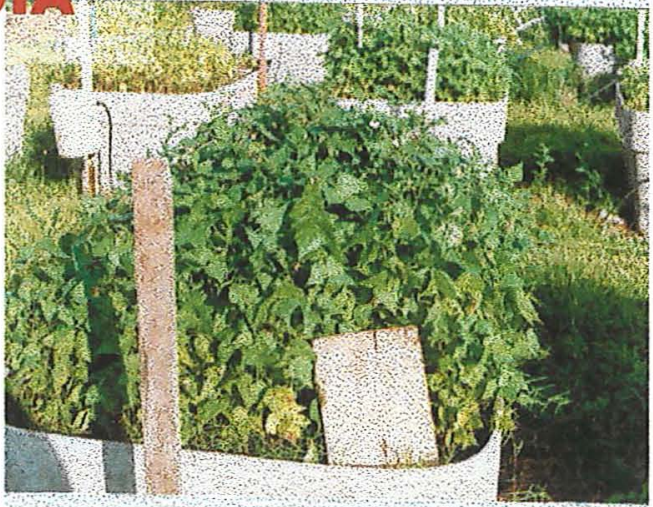



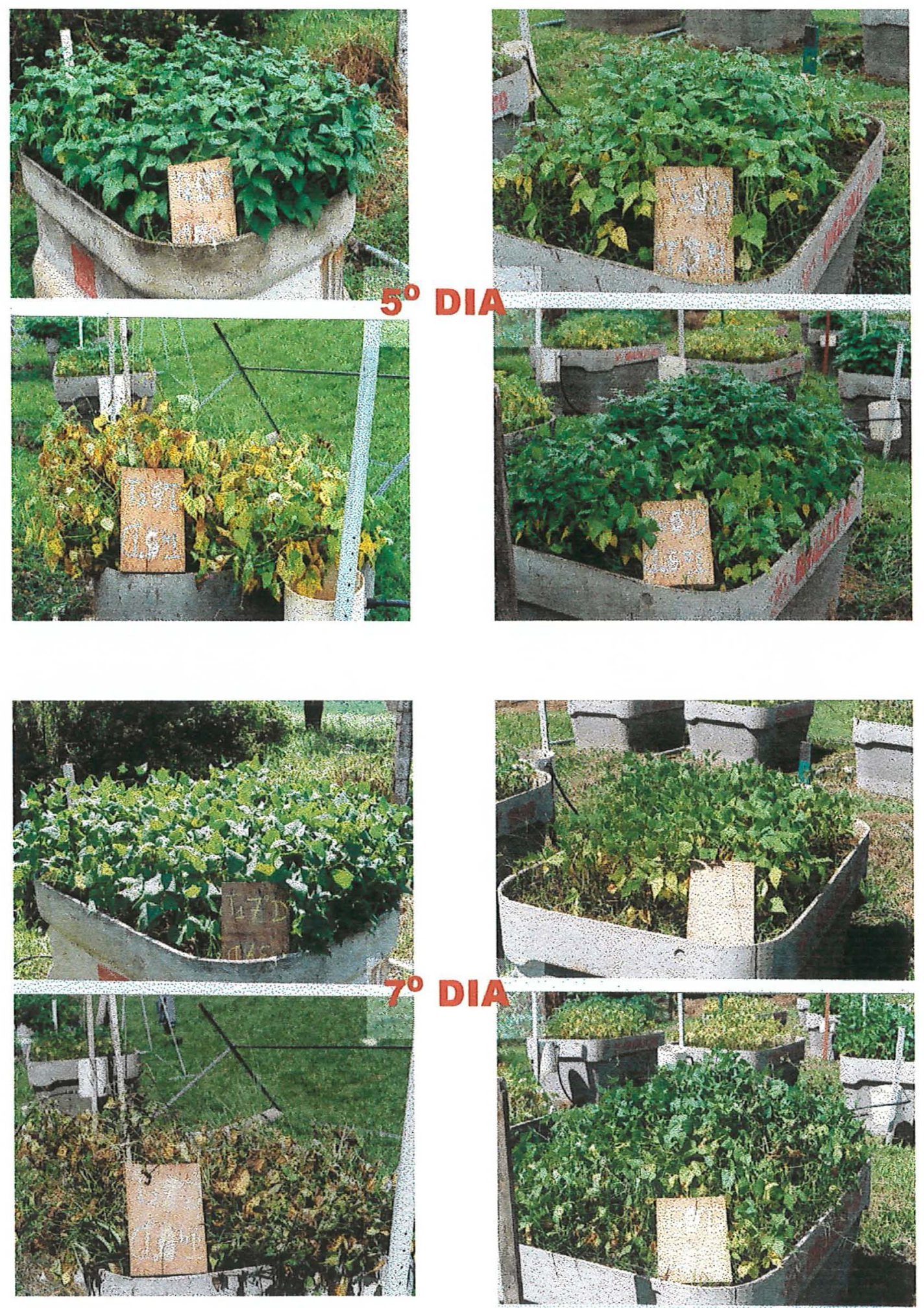

Figura 24. Efeito da hipoxia do $1^{\circ}$ ao $7^{\circ}$ dia do $\mathrm{TAH}$, nos diferentes tratamentos hipóxicos, comparados com a testemunha. Piracicaba, SP, ESALQ/USP. 
5.3.7 - Parâmetros de trocas gasosas. Após 24 hs de aplicação do TAH, a temperatura foliar apresentava-se sem grandes alterações entre os tratamentos, registrando uma amplitude de $1,9^{\circ} \mathrm{C}$. Já a $120 \mathrm{hs}$, o $\mathrm{T}_{4}$ apresenta-se com o valor ligeiramente menor, enquanto na de 96 hs após o T.A.H., todos os tratamentos (com exceção do $T_{2}$ que já havia morrido) registrcram, praticamente a mesma temperatura. (Figura 25A).

As avaliações da resistência estomática (figura 25C) mostraram nítida elevação dos valores da curva - incluindo o $\mathrm{T}_{1}$ - de 24 hs para 120 hs devendo-se, evidentemente às condições climáticas diferenciadas, principalmente a temperatura e a umidade relativa (Figura 25B) €ะ estádio fenológico da planta. Numa comparação entre diferentes datas de amostragem é possivel isolar-se esse fator analisando-se as amplitudes relativas em relação ao $T_{1}$. Corr. 24 hs de T.A.H., pode-se considerar que o pico apresentado pelo $\mathrm{T}_{2}$ já seria uma manifestação do estresse tentando a planta aumentar a conservação de sua água metabólica em resposta à restrição na absorção via radicular. Diferentes autores apontam o aumento da resistència estomática como principal mecanismo para a redução da transpiração (BRADFORD \& YANG, 1981).

Por outro lado, os resultados foram o oposto do encontrado por WHITE \& MOLANO, 1994, também em feijoeiro, quando o "cultivo em solo encharcado" diminuiu a resistência estomática. A diferenciação entre as formas de aplicação da água e o sistema de plantio empregados naquele e neste trabalho foram, sem dúvida, o responsável por essa discordância. 
Já após 120 hs de T.A.H., o $\mathrm{T}_{2} \mathrm{em}$ maior intensidade, porém também o $\mathrm{T}_{3}$ e o $\mathrm{T}_{4}$, apresentaram amplitudes bem superiores daquelas obtidas na $1^{0}$ avaliação. Isso deve-se, obviamente, ao tempo diferenciado de submissão ao estresse, exigindo um maior esforço das plantas para restringir a perda de sua água constituinte. Correlacionando a resistência estomática com o sistema radicular, pode-se inferir aqui que a resistência estomática menor do $T_{4}$ em relação ao $T_{3}$ interpreta-se como uma compensação do esforço na maior emissão de raízes adventícias.

Após 96 hs do final do T.A.H., com as plantas do $T_{2}$ praticamente mortas, observou-se uma notável diminuição da resistência estomática no $T_{3}$ tendo-se como referencia o $T_{1}$, podendo atribuir-se essa recuperação aos fatores de adaptação. Já o $T_{4}$ apresentou-se com valor mais elevado, comportamento esse, concordante com SINGH et al. (1991).

Pode-se interpretar que o $\mathrm{T}_{3}$, com sistema radicular mais adaptado - menor porosidade e mais profundo - àquela nova condição de menor grau de saturação conseguiu ser relativamente mais efetivo, enquanto o delicado e mais poroso sistema radicular do $T_{4}$ pode ter, inclusive se secado. Quanto aos resultados obtidos pelo autor citado, o manejo da água empregado, não favorável à adaptação, pode ser apontado como a causa da discordância na resposta.

Teoricamente, a transpiração deve ser inversamente proporcional à resistência estomática. Observa-se que isso rigorosamente ocorreu nas duas curvas, na $1^{\mathrm{a}}$ e na $3^{\mathrm{a}}$ avaliação, embora em amplitude diferentes dado à natureza dos parâmetros. Isso já não ocorreu perfeitamente aos 120 hs de T.A.H. quando a menor resistência estomática do 
$T_{4}$ em relação ao $T_{3}$ rão traduziu-se em maior transpiração, embora os valores sejam muito próximos (Figura 25D). Os resultados temporais, no entanto, são concordantes com WADMAN \& ANDEL (1985), em feijoeiro, cuja transpiração reduziu-se em 35\% com um dia de encharcamento, alcançando um mínimo no $6^{\circ}$ dia, iniciando-se então uma muito lenta recuperação.

De modo geral, comparativamente com países de clima temperado, os efeitos decorrentes das relativas elevadas temperaturas tanto atmosférica como de solo tendem à requerer muito mais estudo para se ter sucesso nesse tipo de experimentação em nosso meio.

5.3.8 - Parâmetros biométricos de produção. Às 120 hs de T.A.H. os $T_{2}, T_{3}$ e $T_{4}$ já apresentavam sintomas de hipoxia. No entanto, o $T_{2}$ demostrava estar sentindo muito mais, mesmo favorecido pelo clima nos 3 dias. Diferentemente, o $\mathrm{T}_{3} \mathrm{eT}_{4}$ apresentavam sintomas em menor grau, inferindo-se estarem fazendo uso dos processos adaptativos.

Um dia após a suspensão do T.A.H., ou seja, inicio da reoxigenação do solo, o $\mathrm{T}_{2}$ já apresentava-se :otalmente comprometido. Esse mesmo efeito foi observado por GARRITY \& PERNITO (1996) em feijão Mungo (Vigna radiata, L.) submetido a 5 dias de encharcamentı. Por outro lado, o mesmo não ocorria com o $T_{3}$ e $T_{4}$, sem diferença visual entre os dois tratamentos, mantendo-se segurando as folhas até aos 14 dias após o T.A.H., quando iniciou a senescência.

A data de colheita mais longa nos $T_{3}$ e $T_{4}$ em relação ao $T_{1}$ (Quadro 2) pode ser atribuida a um retardamento, exclusivamente função do efeito da hipoxia a partir do periodo reprodutivo, uma vez que todos os tratamentos atingiram o florescimento 
juntos. Este resultado em parte concordante com o observado por UMAHARAN et al. (1997), em feijão Caupi, considerando-se a condição de encharcamentos periódicos durante todo o ciclo da planta, porém discordante daquela em que a hipoxia foi aplicada apenas no estádio reprodutivo. Essa diferenciação de respostas pode ser atribuído a uma adaptação fisiomorfolígica das plantas atingidas neste trabalho e não no do referido autor. O manejo da água diferenciado deve ser considerado como o responsável.

A grande e significativa diferença entre o $T_{1}$ e $T_{2}$ no rendimento de grãos mostrou o quanto determinante pode ser o efeito final da hipoxia repentina, observada na prática, em inundạ̧ões ocasionais das várzeas. Já os diferentes manejos do lençol não promoveram diferença estatística embora o pior desempenho do $T_{2}$ seja notável. Essa não significância não deve ser entendida como ausência de vantagens da indução dos processos adapta:ivos. Isso porque, ao contrário das plantas do $T_{3}$ e $T_{4}$ que permaneceram vivas após o T.A.H., as do $T_{2}$ parecem ter paralisado subitamente seu desenvolvimento e morrido. Isso é evidenciado pela pior massa de mil sementes, significativamente menor que o $T_{1}$ e $T_{3}$ e também o pior numero de grãos por vagem, significativamente menor que $\circ T_{4}$, parâmetros esses de grandeza fortemente influenciadas no estádio em que ocorreu a aplicação do TAH. Ressalta-se que a não significancia estatística nesse último parâmetro entre os $T_{1}, T_{3}$ e $T_{4}$ é concordante com o obtido por UMAHARAN et al. (1997). Por outro lado, a não significância do numero de vagens por plantia entre os tratamentos adaptados $\left(T_{3}\right.$ e $\left.T_{4}\right)$ e o não $\left(T_{2}\right)$ pode ser função também da época da aplicação do T.A.H. ter sido posterior à influência na grandeza desse parâmetro. Já a diferença estatística e/ou a tendência de redução este 
parâmetre nos tratamentos hipóxicos em relação ao Tl é concordante com o obtido por

UMAHARAN et al: (1997).
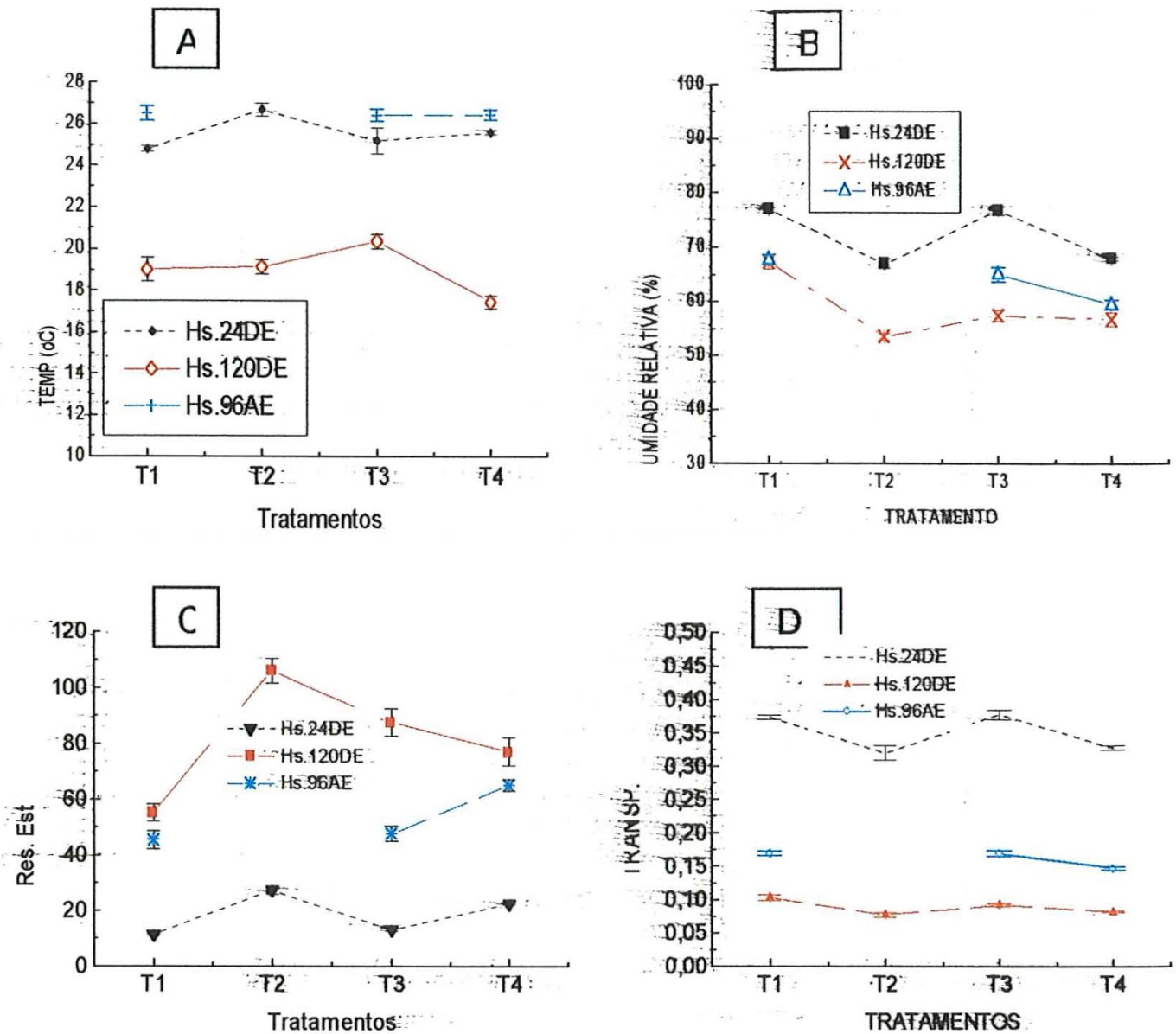

Figura 25. A) Alterações da temperatura da folha; B) Umidade relativa (\%); C) Resistência estomática e D) na taxa transpirométrica do feijoeiro, nos diferentes tratamentos, 24 hs do T.A.H., 120 hs e 96 hs após o T.A.H. Médias seguidas da mesma letra não diferem entre si. Tukey 5\%. Médias e Erro Padrão n=10. Piracicaba, SP, ESALQ/USP.

O mesmo raciocínio anterior pode ser usado na analise da não significância da soma do comprimento das vagens entre $o T_{2}$ e o $T_{1}$ onde, provavelmente por ocasião 
da T.A.H. já tinha sido formado parte das vagens da planta. Já entre o $T_{3}$ e o $T_{4}$, novamente a hipótese sobre o gradiente de esgotamento mais intenso no $T_{4}$ que no $T_{3}$ pode ser usado na análise da soma do comprimento das vagens, com o $\mathrm{T}_{4}$, embora não significativo estatisticimente produzindo $20 \%$ menos que o $\mathrm{T}_{3}$, prejudicado, talvez, pelo dreno de fotoassimilados representado pelas raízes adventícias.

Analisando-se conjuntamente os aspectos climáticos e parâmetros biométricos tem-se que, mesmo sob condições climáticas em que a temperatura e a precipitação, em cada estádio, ao longo do ciclo fenológico, apresentaram-se, favoráveis ao tratamento não adaptado $\left(\mathrm{T}_{2}\right)$ e desfavoráveis aos tratamentos hipóxicos $\left(\mathrm{T}_{3}\right.$ e $\left.\mathrm{T}_{4}\right)$, os parâmetros biométricos de colheita numero de grão por vagem e peso de mil sementes evidenciaram a efetividade adaptativa dos manejos do lençol freático empregados. Avançando na análise, a diferença significativa na massa de mil sementes entre o $T_{3}$ e $\mathrm{T}_{4}$, pode ter sido causada pelo efeito da reoxigenação que, embora o rebaixamento tenha sido executado na mesma intensidade, o $T_{3}$, pela melhor adaptação à este novo estresse e. mais pronta normalização da taxa transpirométrica, como já discutido anteriormente, apresentou melhor performance que o $\mathrm{T}_{4}$. Baseando-se nesses dados e, considerando-se ainda que o $T_{4}$ teve urn efeito mitigador mais efetivo no numero de grãos por vagem e no numero de vagens por planta, pode-se inferir que as vantagens adaptativas temporais da elevação gradativa do lençol freático, por ocasião da formação de vagens e grãos por vagem perderam sua importância na performance final, teoricamente pelo menor acúmulo de fotoassimilados na planta e também talvez pelo dreno raizes adventícias vantagem essa, porem sem tempo para se tornar beneficio pelo curto ciclo da planta de 
feijão. Talvez cultivares de ciclo mais longo seriam mais favorecidos como o apontado por NATHANSON et al., 1984, em cultivares de soja de ciclo longo sob "cultivo em solo saturado".

Tabela 13. Parâmetros biométricos de crescimento e de colheita do feijoeiro. Piracicaba, SP, ESALQ/USP.

\begin{tabular}{|c|c|c|c|c|c|c|c|c|c|c|c|c|}
\hline \multirow[b]{2}{*}{ Trat. } & \multicolumn{5}{|c|}{ Parâmetros de crescimento ${ }^{(1)}$} & \multicolumn{7}{|c|}{ Parâmetros de colheita } \\
\hline & $\begin{array}{r}\text { A P } \\
(\mathrm{cm})\end{array}$ & NF & $\begin{array}{c}\text { MPA } \\
\text { (g.pl-1) }\end{array}$ & $\begin{array}{l}\text { M V } \\
(\mathrm{g})\end{array}$ & $\begin{array}{c}\mathrm{AF} \\
\left(\mathrm{cm}^{2}\right)\end{array}$ & $\begin{array}{c}\text { Colh. } \\
\text { (D.A.E.) }\end{array}$ & $\begin{array}{c}\text { Pop } \\
\left(\text { PI. } \mathrm{m}^{-1}\right)\end{array}$ & $N V^{\prime}$ & NGV & $\begin{array}{l}\text { SCV } \\
(\mathrm{cm})\end{array}$ & $\begin{array}{l}\text { MMS } \\
(\mathrm{g})\end{array}$ & $\begin{array}{l}\text { Rend. } \\
\left(\mathrm{Kg}^{\left.-\mathrm{ha}^{-1}\right)}\right.\end{array}$ \\
\hline$T_{1}$ & $55,3 a$ & $26,6 \mathrm{a}$ & $28,7 \mathrm{a}$ & $7,3 \mathrm{a}$ & $433,4 \mathrm{a}$ & 102 & 17,6 & $5,2 \mathrm{a}$ & $4,0 a b$ & $27,4 a$ & $381,3 \mathrm{a}$ & 3808, 1a. \\
\hline $\mathrm{T}_{2}$ & & & & & & 86 & 17,2 & $3,6 \mathrm{ab}$ & $3,0 \mathrm{~b}$ & $24,8 \mathrm{a}$ & $261,7 b$ & $1323,2 \mathrm{~b}$ \\
\hline$T_{3}$ & $38,6 \mathrm{~b}$ & $24,6 \mathrm{a}$ & $19,3 b$ & $4,6 a b$ & $289.8 \mathrm{~b}$ & 110 & 18,0 & $2,3 b$ & $3,5 \mathrm{ab}$ & $19,2 \mathrm{ab}$ & $363.7 \mathrm{a}$ & $1671,6 \mathrm{~b}$ \\
\hline $\mathrm{T}_{4}$ & $41,9 b$ & $12,7 \mathrm{~b}$ & $12,1 \mathrm{c}$ & $3,2 b$ & $168,4 \mathrm{c}$ & 110 & 17.6 & $2,6 \mathrm{~b}$ & $4,1 \mathrm{a}$ & $15,4 \mathrm{~b}$ & $294,5 b$ & $1412,6 b$ \\
\hline T. F & $26,3^{*}$ & $22,3 *$ & $17,6^{*}$ & $4,7^{*}$ & $59,3^{*}$ & & & $10,7^{*}$ & $3,8^{*}$ & $4,9^{*}$ & $17,7^{*}$ & $74,7^{*}$ \\
\hline $\mathrm{CV}(\%)$ & 12,0 & 23,6 & 32,0 & 55,3 & 18,3 & & & 26,1 & 15,3 & 42,4 & 9,2 & 14,8 \\
\hline
\end{tabular}

T. F. $\left({ }^{*}\right)$ - Teste F - Grau de signif à nivel de 5\%. Teste Tukey - Médias c/ a mesma letra nåo diferem entre si; (1) $\mathrm{T}_{2}=\mathrm{T}_{1}$

Trat - tratamento

AP - altura da planta

NF - número de folhas da $\mathrm{pl}$.

MPA - massa da parte aérea/pl.

MV - massa das vagens'pl.

$\mathrm{AF}$ - área foliar/pl.
Colh - data de colheita

Pop - população de plantas

NV - num. de vagem/pl.

NGV - num. de grão por vagem

$\mathrm{SCV}$ - soma do comp/to vagens/pl.

MMS - massa mil sementes

Rend - rendi/to de grãos. 


\section{4 - CONCLUSÕES}

- Os parâmetros biométricos de crescimento, embora acusando prejuízo da hipoxia, evidenciaram a utilização pela planta de mecanismos adaptativos morfológicos (raízes adventícias e lenticelas), biológicos (fixação de $\mathrm{N}$ ) e fisiomorfológicos (resistividade estomática e transpiração).

- Em plantas submetidas à hipoxia, o estudo da nodulação só será completo se respeitar a dinâmica de emissão de raízes adventícias, dado a gradativa substituição de raizes normais pelas adventícias e a constatação, nesse trabalho de efetivo aproveitamento destas pelo rizóbio.

- Mesmo sob condições climáticas desfavoráveis quanto à maximização de efeitos, os parâmetros biométricos de colheita evidenciaram a efetividade adaptativa tanto do manejo do lençol estabilizado a $15 \mathrm{~cm}$ como o elevado gradativa, permitindo a planta completar seu ciclo com menor comprometimento da qualidade de grãos.

- A alternâncic de vantagens relativas nos parâmetros biométricos de colheita entre os manejos de lençol estabilizado a $15 \mathrm{~cm}$ e com elevação gradativa resultando na não diferença estatística no rendimento de grãos, leva-se à recomendação do uso de cultivares de ciclo mais longo ne:sse tipo de estudo. 


\section{6 - CONCLUSÕES GERAIS}

Para o trigo sob encharcamento, os resultados apontam que:

- O potencial de água na folha foi afetado pela completa submergência da parte subterrânea, já em sua menor duração, não havendo, porém, correspondência com a manifestação fenotípica da cultura;

- A resposta diferenciada de exigência nutricional e/ou capacidade extração entre as duas espécies sob hipoxia indica que o sucesso produtivo do trigo sob hipoxia pode vir a ser condicionado a estudos específicos sobre suas exigências específicas e, consequentemente, a um plano de fertilização mais ajustado;

- A adubação foliar não contribuiu para suprir as deficiências nutricionais da planta decorrentes da limitação na absorção via sistema radicular, causada pela hipoxia no solo ou, se o fez, foi de forma insuficiente, sugerindo-se estudos específicos;

- A resistividade estomática mostrou-se o parâmetro de maior sensibilidade na planta de trigo sob encharcamento;

- Os manejos empregando curtos períodos de hipoxia induziram adaptações fisiomorfológicas tais que permitiram a sobrevivência das plantas mesmo sob encharcamento contínuo por mais de 50 dias. Essas, porém, não o foram na intensidade ou eficiência que resultassem parâmetros de produção num nível adequado;

- O manejo do lençol freático mantido a $15 \mathrm{~cm}$ de profundidade durante todo o ciclo fenológico foi o que propiciou melhor performance do trigo; 
- A submergência intermitente mostrou-se altamente prejudicial, com o efeito intensificando-se com o aumento da freqüência da submersão, não sustentando a tese da transmissividade oı acúmulo de induções adaptativas.

Para o feijão pode-se observar que:

- Os parâmetros biométricos de crescimento, embora acusando prejuizo da hipoxia, evidenciaram a utilização pela planta de mecanismos adaptativos morfológicos (raízes adventícias e lenticelas), biológicos (fixação de N) e fisiomorfológicos (resistividade estomática e transpiração).

- Em plantas submetidas à hipoxia, o estudo da nodulação só será completo se respeitar a dinâmica de emissão de raízes adventícias, dado a gradativa substituição de raízes normais pelas adventícias e a constatação, nesse trabalho de efetivo aproveitamento destas pelo rizóbio.

- Mesmo sob condições climáticas desfavoráveis quanto à maximização de efeitos, os parâmetros biométricos de colheita evidenciaram a efetividade adaptativa tanto do manejo do lençol estabilizado a $15 \mathrm{~cm}$ como o elevado gradativa, permitindo a planta completar seu ciclo com menor comprometimento da qualidade de grãos.

- A alternância de vantagens relativas nos parâmetros biométricos de colheita entre os manejos de lençol estabilizado a $15 \mathrm{~cm}$ e com elevação gradativa resultando na não diferença estatística no rendimento de grãos, leva-se à recomendação do uso de cultivares de ciclo mais longo nesse tipo de estudo. 


\section{REFERÊNCIAS BIBLIOGRÁFICAS}

BARCLAY, H. M. \& CRAWFORD, R. M. M. Plant growth and survival under strict anaerobiosis. J. Exp. Bot., 22:541-549, 1982.

BEARD, J. B. \& MARTIN, D. P. Influence of water temperature on submersion tolerance of four grasses. Agron. J., 62, 257, 1970.

BLACKWELL, P. S. Measurements of aeration in waterlogged soils: some improvements of techniques and their application to experiments using lysimeters. J. Soil Sci., 34: 271$285,1983$.

BRADFORD, K. J. \& YANG, S. F. Physiological responses of plants to waterlogging. HortScience, 16:25-30, 1981.

CANNELL, R. Q.; BELFOFD, R. K. GALES, K. DENNIS C. W. \& PREW, R. D. Effects of waterlogging at different stages of development on the growth and yield of winter wheat. J. Sci. Food Agric., 31:117-32, 1980.

CRAWFORD, R. Mi. M. \& BRAENDLE, R. Oxigen deprivation stress in a changing environment. J. Exp. Bot. 47(295):145-9, 1996.

DINIZ, A. J.; FERREIRA, M. M.; VALE, F. R. \& RAMALHO, M. A. P. Avaliação de níveis de água no solo visando a seleção de cultivares de feijoeiro para o cultivo em solos de várzea. Cienc. e Prat. Lavras, 17(2):113-9, 1993.

DREW. M. C. Soil aeration and plant root metabolim. Soil Science, 154: (4), 1992

DREW, M. C. \& SISWOR.O, E. J. The development of waterlogging damage in young barley plants in relation to plant nutrient status and changes in soil properties. New 
Phytol., 82: 301, 1979.

GARRITY, D. P. \& PERNITO, R. Mungbean response to surface drainage when grown as a pre-rice crop on waterlog-prone ricelands. Agric. Water Managem.ent, 29:299-314, 1996.

GINKEL, M. VAN; RAJAFAM, S.; TBIJSEEN, M.; TANNER, D. G. \& MWANGI, W. J. Waterlogging in wheat: germoplasm evaluation and methodology development. Seventh regional wheat workshop for eastern, central and southern Africa, Nakuru, Kenia, 16-19. Sept., : 991. 1992, 115-24. / Resumo em CAB Abstracts on CD-ROM, 1993.

GLINSKI J. \& STEPNIEW SKI W. Soil aeration and its role for plants. CRC Press Inc, Florida. 228 p, 1986.

HERRMANN, P. S. P.; ANDRADE, M. G.; COlMAGO, L. A. \& SILVEIRA, P. M. Equipamento para medida da taxa de difusão de oxigênio e potencial de oxiredução no solo. Pesq. Agrop. Bras., 32(7): 725-30,1997.

HODGSON, A. S.; HOLLAND, J. F. \& RAYNER, P. Effects of field slope and duration of furrow irrigation on growth and yield of six grain-legumes on a waterlogging-prone vertisol. Field Crops Research, 22: 165-80, 1989.

HONG, T. D., MINCHIN, F. R. \& SUMMERFIELD, R. J. Recovery of nodulated cowpea plants (Vigna unguiculata (L) Walp.) from waterlogging during vegetative growth. Plant and Soil, 48, 661-72, 1977.

HOOK, D. D. \& BROWN, C. L. Root adaptation and relative flood tolerance of five gardwood species. For. Sci. 19: 22-9, 1973. 
HUANG, B. R. JOHNSON, J. W.; NESMITH, S. \& BRIDGES, D. C. Growth, Physiological and anatomical responses of two wheat genotypes to waterlogging and nutrient supply. J. of Exp. Botany, 45(271): 193-202, 1994.

HUCK, M. G. Variation in taproot elongation rate as influenced by composition of the soil air. Agron. J. 62: 815, 1970.

JACKSON, M. B., GALES, K., CAMPBELL, D. J. Effect of waterlogged soil conditions on the production of ethylene and on water relationships in tomato plants. J. Exp. Bot., 29: 183, 1978.

JACKSON, M. B. \& HALL, K. C. Early stomatal clousure in waterlogged pea plants is mediated by abscisic acid in the absence of foliar water deficits. Plants, Cell and Environ. 10:120-30, 1987.

JOHNSON, J. COBB, B. G. \& DREW, M. C. Hypoxic induction of anoxia tolerance in roots of Zea mays, L. Plant Physiol. 1: 873-41. 1989.

JOLY. C. A. Flooding tolerance: a reinterpretation of Crawford's metabolic theory. Proc. of the Royal Society of Edinburgh. 102B, 343-54, 1994.

JUSTIN, S. H. F. \& ARMSTRONG, W. The anatomical characteristics of roots and plant response to soil flooding. New Phytol., 106: 465-95, 1987.

KAWASE, M. Aerenchyma formation: How plants adapt to waterlogging. Ohio Report on Research and Development, 63:1, 14-5. 1978.

KAWASE, M. Anatomical and morphological adaptation of plants to waterlogging. HortScience.. 16: 8-12, 1981.

KOZLOWSKI, T. T. Flooding and Plant Growth. Academic Press, Inc. 1984. New York . 
168p.

LABANAUSKAS, C. K. ; STOLZY, L. H. AND LUXMOORE, R. J. Soil temperature and soil aeration effects on concentration and total amounts of nutrients in "Yecora" wheat grain. Soil Sci. 120: 450, 1975.

LETEY, J.; LUNT, O. R.; STOLZY, L. H. \& SZUSKIEWCZ, T. E. Plant growth, water use and nutritional response to rhizosphere differentials of oxygen concentration. Soil Sci. Soc. Am. Proc. 25: 183, 1961.

LU, J. The injury to winter wheat growth by soil waterlogging and its mechanism. Acta Phytophysiologica Sinica. 20(3): 221-6, 1994.

MINCHIN, F. R. \& SUMMERFIEL R. J. Symbiotic nitrogen fixation and vegetative growth of cowpea (Vigna unguiculata, (L.) Walp.) in waterlogged conditions. Plant and Soil, $45: 113-27,1976$.

MONK, L. S., FAGERSTEDT, K. V. \& CRAWFORD, R. M. M. Oxygen toxicity and superoxide dismutase as antioxidant in physiological stress. Physiol. Plant, 76: 4569. 1989.

NATHANSON, K.; LAWN, R. J.; DE JABRUN P. L. M. \& BYTH, D. E. Growth, nodulation and nitrogen accumulation by soybean in saturated soil culture. Field Crops Research., 8: 73-92, 1984.

NAWATA, E.; YOSHINAGA, S. AND SHIGENAGA, S. Effects of waterlogging growth and yield of yard long bean (Vilna sinenis var. sesquipedalis). Trop. Agric. Res. Series, 23: $174-81,1990$.

PEREIRA, J. S. \& KOZLOWSKI, T. T. Variation among woody angiosperms in response to 
flooding. Physiol. Plant. 41: 184-92, 1977.

POEL, L. N. A Preliminary survey of soil aeration condition in a Scottish hill grazing. J. Ecol. 48: 733-6, 1960.

PONNAMPERUMA, F. N. Effect of flooding on soils. In: KOZLOWSKI, T. T. (ed), Flooding and Plant Growth. London. Academic Press, 1984. p. 9 - 45.

RaIJ, B. VAN; CANTAREla, H; QUaGgio, J. A.;. \& FuRlani, A. M. C. Recomendação de adubação e calagem para o Estado de São Paulo. Campinas: Instituto Agronômicc, 1996. 285 p. (IAC. Boletim Técnico 100).

RALPH. W. Soybean respord to controlled waterlogging. Rural Research, 120:4-8, 1983. RICARD, B.; COUÈE, I; RAYMOND. P. SAGLIO, P. H.; SAINT-GES, V. \& PRADET, A. Plant metabolism under hypoxia and anoxia. Plant Physiol. Biochem. 32 (1) 1-10, 1994.

ROWLAND, L. J. \& STR.OMMER, J. N. Anaerobic treatment of maize roots effects transcription of Adh1 and transcript stability. Mol. Cell. Biol., 6: 3368-72, 1986.

SACHS, M. M.; FREELING, M. \& OKIMOTO, R. The anaerobic proteins of maize. Cell. 20: $761-7,1980$.

SAGLIO. P. H.; DREW, M. C. \& PRODET, A. Metabolic acclimation to anoxia induced by low (2-4 KPa partial pressure) oxygen pretreatment (hypoxia) in root tips of Zea mays. Plant Physiol., 86: 61-6, 1988.

SCHAFFER, B; ANDERSEN, P. C. \& PLETZ, R.C. Responses of fruits crops to flooding. In: JANICK, J. (Ed). Hortic. Reviews, V. 13, New York, John Wiley \& Sons, Inc., 1992. p. 257-313. 
SENA GOMES, A. R. \& KOZLOWSKI, T. T. Growth responses and adaptations of Fraxinus pennylvanica seedlings to flooding. Plant Physiol. 66: 267-71, 1980a.

SENA GOMES, A. R. \& KOZLOWSKI, T. T. Responses of Melaleuca quinquenervia seedling to flooding. Physiol Plant. 49: 373-7, 1980b.

SILVERBUSH, M., GORNAT, B. AND GOLDBERG, D. Effect of irrigation from a point source (trickling) on oxygen flux and on root extension in the soil. Plant Soil, 52: $507,1979$.

SINGH, B. P.; TUCKER, K. A.; SUTTON, J. D. \& BHARDWAJ, H. L. Flooding reduces gas exchange and grcwth in snap bean. HortScience, 26(4): 372-3, 1991.

SOJKA, R. E., STOLZY, L. H. Soil-oxygen effects on stomatal response. Soil Sci. 130: 350, 1980.

SOJKA, R. E., STOLZY, L. H. \& KAUFMANN, M. R. Wheat growth related to rhizosphere temperature and oxygen levels. Agron. J. 67: 591, 1975.

STOLZY, L. H. \& LETEY, J. III. Correlation of plant response to soil oxygen diffusion rates. Hilgardia, 35(20): 567-76, 1964.

TAKELE, A. \& MCDAVID, C. R. Effects of short-term waterlogging on cultivars of cowpea (Vigna unguiculata L. Walp.). Trop. Agric., 71(4): 275-80, 1994.

TROEDSON, R. J.; LAWN. R. J.; BYTH, D. E. \& WILSON, G. L. Saturated soil culture An innovative water management option for soybean in the tropic and subtropics. In: SHANMGASUNDARAM, S. \& SULZBERGER, E. W. (Eds.) Soybean in tropical and subtropical cropping systems, Proc. of a Sump., Tsukuba, Japan, Sept-Oct, 1983. / Resumo em CAB Abstracts on CD-ROM, 1983. 
TROUGHT. M. C. T. \& DFEW, M. C. The development of waterlogging damage in wheat seedlings (Triticum ciestivum L. ). II Accumulation and redistribution of nutrients by the shoot. Plant Soil, 56: 187, 1980.

UMAHARAN, P.; ARIYANAYAGAM, R. P. \& HAQUE, S. Q. Effect of short-term waterlogging applied at various growth phases on growth, development and yield in Vigna unguiculata. J. of Agric. Sci., 128: 189-98, 1997.

TOAI VAN T. T. \& BOLCES, C. S. Post-anoxic injury in soy bean (Glycine max, L.) seedling. Plant. Physiology, 97: 588-92, 1991.

WADMAN-VAN SCHRAVENDIJK, H. \& VAN ANDEL, O. M. Interdependence of growth, water relations and abscisic acid level in Phaseolus vulgaris during waterlogging. Physiol Plant. 63: 215-20, 1985.

WANG, G.; PEOPLES, M. B. HERRIDGE, D. F. \& RERKASEM, B., Nitrogen fixation, growth and yield of soybean grown under saturated soil couture and conventional irrigation. Field Crops Res. 32: 257-68, 1993.

WATERS, I.; MORRELL, S.; GREENWAY, H.; COLMER, T. D. Effects of anoxia on wheat seedlings. II. Influence of $\mathrm{O}_{2}$ suply prior to anoxia on tolerance to anoxia, alcoholic fermentation, and sugar levels. J. of Exp. Botany. 42(244): 1437-47, 1991.

WEBB. T. \& ARMSTRONG, W. The effect of anoxia and carbohydrates on the growth and viability of rice, pea and pumpkin roots. J. Exp. Bot. 34: 579-603. 1983.

WENT. W; MARTINS, S. R. \& CAETANO, V. R. Comportamento de genótipos de trigo em relação ao tempo de: encharcamento de água no solo. XV RENAPET, Resumos. Passo Fundo, RS, 19 a 23 de set., 1988. 
WHITE, W. J. \& MOLANO, C. H. Production of common bean under saturated soil culture.

Field Crops Research, 36: 53-8, 1994.

WIGNARAJAH, K. \& GREENWAY, H. Effect of anaerobiosis on activities of alcohol dehydrogenase and pyruvate decarboxylase in roots of Zea mays, L. New Phytol. 77: $575-84,1976$. 